\title{
X-RAY FLUORESCENCE (XRF) ANALYSIS OF HANFORD LOW ACTIVITY WASTE SIMULANTS METHOD DEVELOPMENT
}

ANALYTICAL DEVELOPMENT

August 8, 2007

Washington Savannah River Company Savannah River Site Aiken, SC 29808

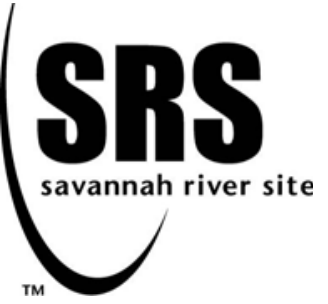




\section{DISCLAIMER}

This report was prepared for the United States Department of Energy under Contract No. DE-AC09-96SR18500 and is an account of work performed under that contract. Neither the United States Department of Energy, nor WSRC, nor any of their employees makes any warranty, expressed or implied, or assumes any legal liability or responsibility for accuracy, completeness, or usefulness, of any information, apparatus, or product or process disclosed herein or represents that its use will not infringe privately owned rights. Reference herein to any specific commercial product, process, or service by trade name, trademark, name, manufacturer or otherwise does not necessarily constitute or imply endorsement, recommendation, or favoring of same by Washington Savannah River Company or by the United States Government or any agency thereof. The views and opinions of the authors expressed herein do not necessarily state or reflect those of the United States Government or any agency thereof.

Printed in the United States of America

Prepared For

U.S. Department of Energy 
Key Words:

Hanford, River Protection Project

XRF, Low Activity Waste

Retention:

Permanent

Key WTP C\&T References:

Statement of Work - CCN091863

Test Plan - WSRC-TR-2004-00563 Revision 3

\section{X-RAY FLUORESCENCE (XRF) ANALYSIS OF HANFORD LOW ACTIVITY WASTE SIMULANTS METHOD DEVELOPMENT}

David M. Missimer, SRNL Arthur R. Jurgensen, SRNL Ronny L. Rutherford, SRNL

August 8, 2007

Washington Savannah River Company Savannah River Site Aiken, SC 29808 


\section{REVIEWS AND APPROVALS}

D. M. Missimer, Task Lead, Analytical Development, SRNL Date

A. R. Jurgensen, Co-Author, Analytical Development, SRNL

Date

R. L. Rutherford, Co-Author, Analytical Development, SRNL

Date

M. E. Summer, Technical Reviewer, Analytical Development, SRNL

Date

F. M. Pennebaker, RPP Program Manager, Analytical Development, SRNL

Date

R. E. Edwards, RPP Project Manager, Process Science \& Engineering, SRNL

Date

L. M. Chandler, Director, Analytical Development, SRNL

Date

A. V. Arakali, C\&T WTP Representative

Date

T. A. Lane, C\&T WTP Representative

Date 
WSRC-STI-2007-00438

SRNL-RPP-2007-00020

\section{TABLE OF CONTENTS}

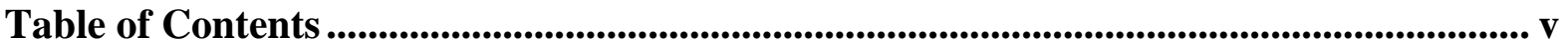

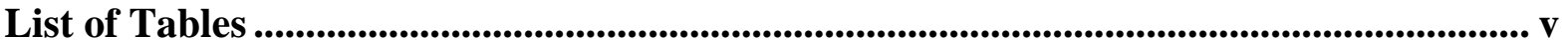

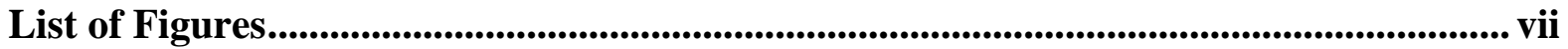

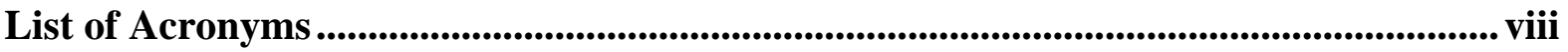

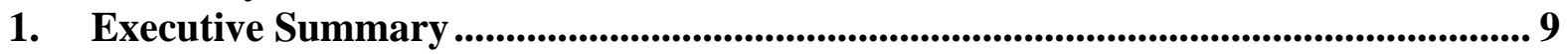

2. Introduction and Background ........................................................................................... 10

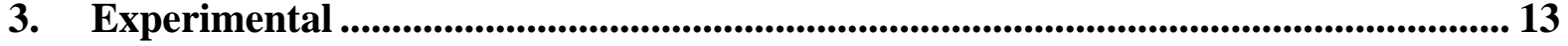

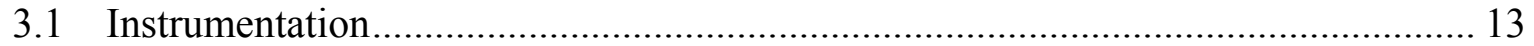

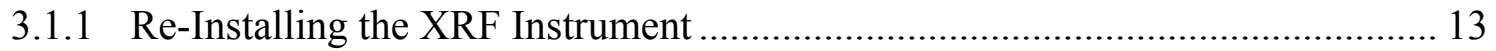

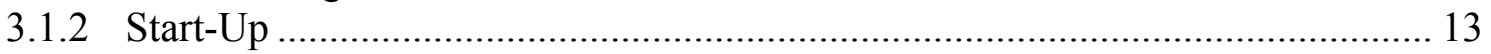

3.1.3 Performance Check ............................................................................... 13

3.1.4 Verification of Standards/Simulants .......................................................... 17

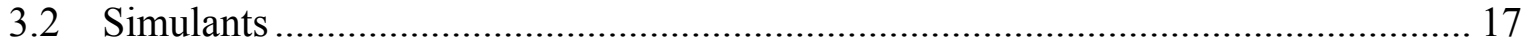

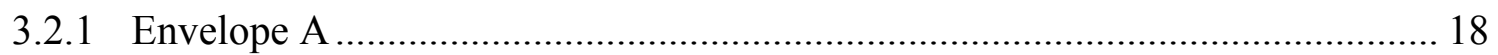

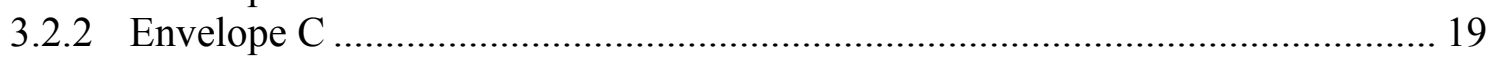

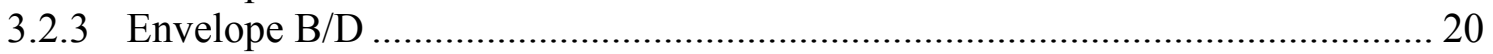

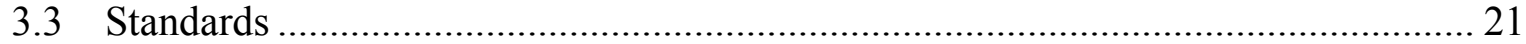

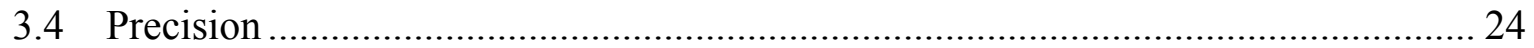

3.5 Quantitative Application File ........................................................................... 24

3.5 Simulant and Standard Preparations................................................................. 26

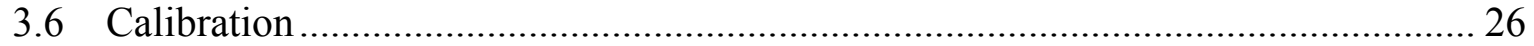

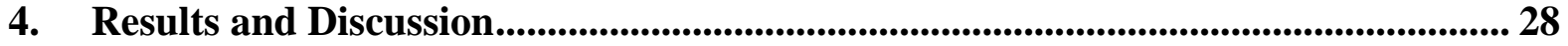

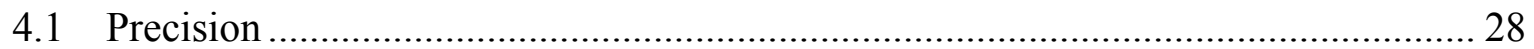

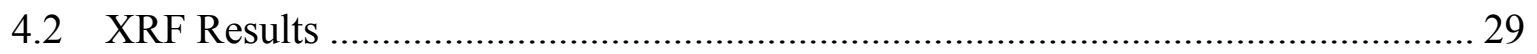

4.3 X-ray Fluorescence (XRF) Counting Statistics .............................................. 34

5. Quality Assurance ....................................................................................................... 35

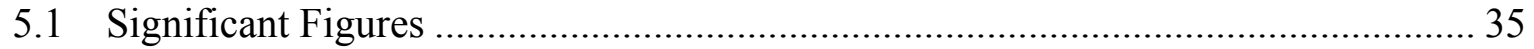

6. Conclusions/ Recommendations ...................................................................... 36

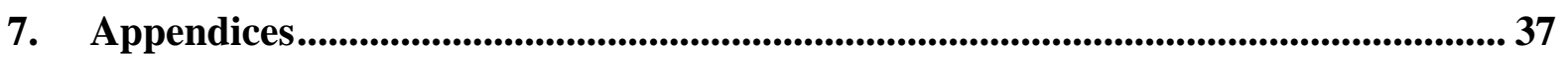

7.1 Appendix A: Simulants Hold Point Approval................................................... 37

7.2 Appendix B: Standard Certificates of Analysis and Material Safety Data Sheets ... 38

7.3 Appendix C: Precision....................................................................................... 59

7.4 Appendix D: Representative Calibration Curves ................................................ 66

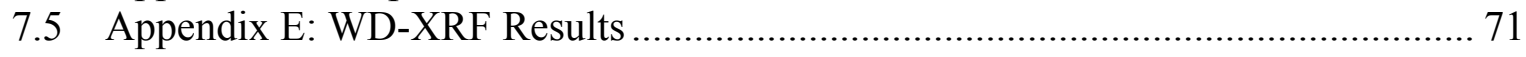

7.6 Appendix F: IC and ICP Simulant and Standard Data ..................................... 76

7.7 Appendix G: XRF Sample and Standard Counting Statistics .............................. 85

\section{LIST OF TABLES}

Table 1. Reported Simulant Compositions................................................................. 12

Table 2. Major Element Concentrations in RPP Simulants............................................ 18

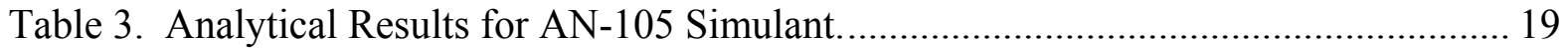

Table 4. Analytical Results for AP-101 Simulant. ............................................................ 19 
Table 5. Analytical Results for AN-107 Simulant....................................................... 20

Table 6. Analytical Results for AZ-101 Simulant. ....................................................... 21

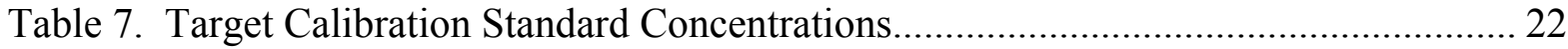

Table 8. High Purity Calibration Standard Concentrations. ............................................... 22

Table 9. ICP-AES and IC Average Concentrations for the High Purity Standards.............. 23

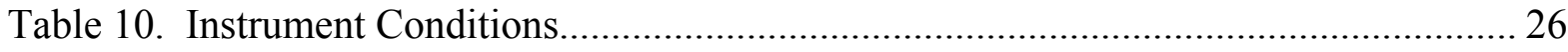

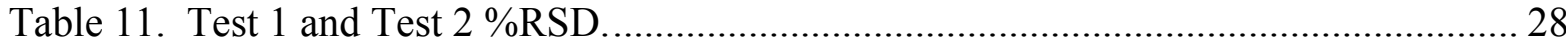

Table 12. Basic and Acidic AP-101 Simulant \%RSD....................................................... 29

Table 13. WD-XRF Average Results for the Three Data Sets. .......................................... 30

Table 14. Average Concentrations for the WD-XRF, Method 1, ICP-AES, and IC ............ 31

Table 15. AN-105 Average Concentrations and Standard Deviation for the WD-XRF Method

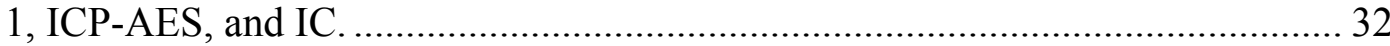

Table 16. AP-101 Average Concentrations and Standard Deviation for WD-XRF Method 1, ICP-AES, and IC.

Table 17. AN-107 Average Concentrations and Standard Deviation for the WD-XRF Method

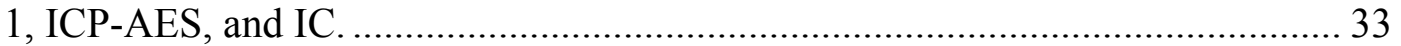

Table 18. AZ-101 Average Concentrations and Standard Deviation for the WD-XRF Method

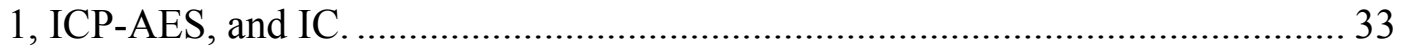

Table 19. Comparing the Overall Precision to the Counting Uncertainty for the Acidic Filtered Diluted Simulants. 34

Table 20. Comparing the Overall Precision to the Counting Uncertainty for the Basic Filtered Diluted Simulants. 35

Table C - 1. AN-105 Simulant Solution Precision - Three Runs of Ten Filtered Undiluted Samples in Autosampler from Previous Report ${ }^{1}$.

Table C - 2. AN-105 Simulant Solution ${ }^{1}$ Precision - Three Runs of Five Filtered Diluted Samples (1:1) in Autosampler.

Table C - 3. AN-105 Simulant Solution ${ }^{1}$ Precision - Fourteen Runs of One Filtered Diluted Sample(1:1) in Autosampler over 8 Hours.

Table C - 4. AN-105 Simulant Solution ${ }^{1}$ Precision - One Filtered Diluted Sample (1:1) in Autosampler Run at Different Times During the Day.

Table C - 5. AN-105 Simulant Solution ${ }^{1}$ Precision - Three Runs of Five Filtered Diluted Samples (1:1) in Autosampler with the Instrument Film Replaced Prior to Each Run.

Table C - 6. AP-101 Simulant Solution ${ }^{1}$ Precision - Three Runs of Five Filtered Diluted Samples (1:1) in Autosampler.

Table C - 7. AP-101 Simulant Solution ${ }^{1}$ Precision - Three Runs of Five Filtered Acidic Samples in Autosampler.

Table E - 1. WD-XRF Analysis of RPP Acidified Simulants. ......................................... 72

Table E - 2. WD-XRF Analysis of RPP Basic Simulants............................................... 73

Table E - 3. WD-XRF Analysis of RPP Acidified Simulants using Drift Correction........... 74

Table E - 4. Quality Control Check Standards Analysis for the Basic and Acidified Runs.. 75

Table F - 1. IC Data for Envelope A, AN-105 Simulant. ............................................... 76

Table F - 2. ICP Data for Envelope A, AN-105 Simulant.............................................. 76 
Table F - 3. IC Data for Envelope A, AP-101 Simulant................................................... 77

Table F - 4. ICP Data for Envelope A, AP-101 Simulant................................................. 77

Table F - 5. IC Data for Envelope C, AN-107 Simulant. ................................................... 78

Table F - 6. ICP Data for Envelope C, AN-107 Simulant. ............................................... 78

Table F - 7. IC Data for Envelope B/D, AZ-101 Simulant............................................. 79

Table F - 8. ICP Data for Envelope B/D, AZ-101 Simulant............................................. 79

Table F - 9. IC Data for High Purity Standard A........................................................... 80

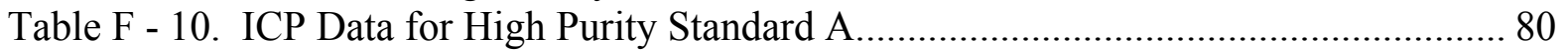

Table F - 11. IC Data for High Purity Standard B........................................................ 81

Table F - 12. ICP Data for High Purity Standard B..................................................... 81

Table F - 13. IC Data for High Purity Standard C. ........................................................ 82

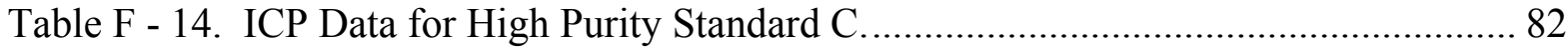

Table F - 15. IC Data for High Purity Standard D................................................... 83

Table F - 16. ICP Data for High Purity Standard D....................................................... 83

Table F - 17. IC Data for High Purity Standard E. .......................................................... 84

Table F - 18. ICP Data for High Purity Standard E...................................................... 84

Table G - 1. WD-XRF Counting Error of RPP Acidified Simulants................................ 85

Table G - 2. WD-XRF Counting Error of RPP Basic Simulants...................................... 86

\section{LIST OF FIGURES}

Figure 1. PHA scan for the flow proportional counter. ............................................ 15

Figure 2. PHA scan for the scintillation detector........................................................... 16

Figure 3. The operational flow bar to create an application file ....................................... 25

Figure B - 1. Standard A Certificate of Analysis............................................................ 39

Figure B - 2. Standard A Material Data Safety Sheet (MSDS)...................................... 41

Figure B - 3. Standard B Certificate of Analysis ............................................................. 43

Figure B - 4. Standard B Material Data Safety Sheet (MSDS) . ................................... 45

Figure B - 5. Standard C Certificate of Analysis......................................................... 47

Figure B - 6. Standard C Material Data Safety Sheet (MSDS). ........................................ 49

Figure B - 7. Standard D Certificate of Analysis............................................................ 51

Figure B - 8. Standard D Material Data Safety Sheet (MSDS)...................................... 53

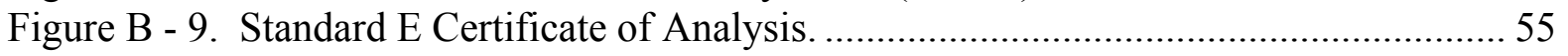

Figure B - 10. Standard E Material Data Safety Sheet (MSDS) ..................................... 57

Figure D - 1. Aluminum calibration curve using all five High Purity standards................. 66

Figure D - 2. Calcium calibration curve using all five High Purity standards..................... 66

Figure D - 3. Chlorine calibration curve using all five High Purity standards. ................... 67

Figure D - 4. Chromium calibration curve using all five High Purity standards................. 67

Figure D - 5. Molybdenum calibration curve using all five High Purity standards.............. 68

Figure D - 6. Nickel calibration curve using all five High Purity standards. ..................... 68

Figure D - 7. Phosphorus calibration curve using all five High Purity standards. ............... 69

Figure D - 8. Potassium calibration curve using all five High Purity standards.................. 69

Figure D - 9. Sodium calibration curve using all five High Purity standards..................... 70 
WSRC-STI-2007-00438

SRNL-RPP-2007-00020

Figure D - 10. Sulfur calibration curve using all five High Purity standards.

\section{LIST OF ACRONYMS}

$\begin{array}{ll}\text { ADD } & \text { Analytical Development Directorate } \\ \text { CRV } & \text { Concentrate Receipt Vessel } \\ \text { FP } & \text { Fundamental Parameter } \\ \text { GFC } & \text { Glass Former Chemicals } \\ \text { HLW } & \text { High Level Waste } \\ \text { HRTL } & \text { Hydrogen Research Technical Laboratory } \\ \text { IC } & \text { Ion Chromatography } \\ \text { ICP-AES } & \text { Inductively Coupled Plasma - Atomic Emission Spectroscopy } \\ \text { IUPAC } & \text { International Union of Pure and Applied Chemistry } \\ \text { LAW } & \text { Low Activity Waste } \\ \text { LDR } & \text { Land Disposal Restriction } \\ \text { MFPV } & \text { Melter Feed Preparation Vessel } \\ \text { MSDS } & \text { Material Data Safety Sheet } \\ \text { NIST } & \text { National Institute of Standard Testing } \\ \text { PC } & \text { Proportional Counter } \\ \text { PHA } & \text { Pulse Height Adjustment } \\ \text { PNNL } & \text { Pacific Northwest National Laboratory } \\ \text { QC } & \text { Quality Control } \\ \text { RPP } & \text { River Protection Project } \\ \text { \%RSD } & \text { Percent Relative Standard Deviation } \\ \text { SC } & \text { Scintillation Counter } \\ \text { SRNL } & \text { Savannah River National Laboratory } \\ \text { SRS } & \text { Savannah River Site } \\ \text { TRU } & \text { Transuranics } \\ \text { WCP } & \text { Waste Compliance Program } \\ \text { WTP } & \text { Hanford Tank Waste Treatment and Immobilization Plant } \\ \text { WD-XRF } & \text { Wavelength Dispersive X-ray Fluorescence } \\ \text { XRF } & \text { X-ray Fluorescence } \\ & \end{array}$


WSRC-STI-2007-00438

SRNL-RPP-2007-00020

\section{Executive Summary}

The x-ray fluorescence laboratory (XRF) in the Analytical Development Directorate (ADD) of the Savannah River National Laboratory (SRNL) was requested to develop an X-ray fluorescence spectrometry method for elemental characterization of the Hanford Tank Waste Treatment and Immobilization Plant (WTP) pretreated low activity waste (LAW) stream to the LAW Vitrification Plant. The WTP is evaluating the potential for using XRF as a rapid turnaround technique to support LAW product compliance and glass former batching. The overall objective of this task was to develop an XRF analytical method that provides rapid turnaround time $(<8$ hours), while providing sufficient accuracy and precision to determine variations in waste.

The Phase $1 \mathrm{~b}$ restored work scope at SRNL consisted of following activities:

- Re-install the XRF instrument,

- Obtain WTP simulant samples representative of LAW envelopes,

- Perform additional precision testing,

- Procure matrix-match standards to calibrate the XRF instrument,

- Develop an XRF method for the WTP using simulant samples representative of the LAW envelopes.

A small precision study was conducted after re-installing the instrument and procuring new standards. As reported earlier by Jurgensen ${ }^{1}$, there were some issues with a few elements precipitating out of the basic solution over time which affected the long term precision of the method. The precision results improved by diluting the simulant sample, but the precipitation issue continued to persist. Simulant precipitation was resolved by converting the basic stimulant to an acid matrix. The precision improved from $<10 \%$ to $<5 \%$ for the simulant, AP-101, when the simulant was converted from basic to acidic.

Three XRF fundamental parameters methods were studied, acidic, basic, and drift correcting. A thorough statistical analysis of the results was conducted. The analysis compared Methods 1 and 2 (acidic to basic) to the ICP-AES and IC. Method 3 (drift correcting) was not included in the statistical analysis due to an imperfect drift correction of the x-ray intensities. The results of the statistical evaluation suggest that Method 1 (acidic) is significantly similar to the ICP-AES and IC. The statistically analysis is referenced in the Results section in this report.

\footnotetext{
${ }^{1}$ A. R. Jurgensen, D. M. Missimer, and R. L. Rutherford, "X-ray Fluorescence (XRF) Analysis of Hanford Low Activity Waste Simulants", WSRC-TR-2006-00137, SRNL-RPP-2006-00019, Savannah River Site, Aiken SC 29808 (May 8, 2006).
} 
WSRC-STI-2007-00438

SRNL-RPP-2007-00020

\section{Introduction and Background}

This document addresses the Savannah River National Laboratory (SRNL) Phase 1b method development activities detailed in task plan WSRC-TR-2004-00563, Rev3 ${ }^{2}$ in support of using $\mathrm{X}$-ray fluorescence (XRF) spectrometry for elemental characterization of the Hanford Waste Treatment and Immobilization Plant (WTP) pretreated low activity waste (LAW) stream to the LAW Vitrification Plant. The WTP is evaluating the potential for using XRF as a rapid turnaround technique to support LAW product compliance and glass former batching. The overall objective of this task was to develop XRF analytical methods that provide the rapid turnaround time $(<8$ hours) requested by the WTP, while providing sufficient accuracy and precision to determine waste composition variations.

The LAW stream is primarily a liquid supernatant comprised of sodium hydroxide and sodium nitrate. It also contains trace metals, sulfate, aluminum, and potassium and up to $3.8-\mathrm{wt} \%$ entrained solids. The waste will be transferred from the tank farms to the Pretreatment Facility in batches up to 5,700,000-L. If required, the LAW stream will be concentrated up to a 5-molar (M) sodium concentration and filtered to remove any entrained solids. As necessary, strontium and transuranics (TRU) will be removed using a permanganate precipitation process and blended with the high level waste (HLW) feed. Cesium will be separated next using an ion exchange resin. The low activity treated waste will then be concentrated along with any LAW vitrification recycle solutions to 5 to 8 -M sodium. The target concentration of the treated LAW batch will be defined by the relative concentrations of sodium and sulfate.

The Pretreatment Facility is designed to provide sufficient pretreated LAW feed to produce 90,000-kg of LAW glass per day. For LAW vitrification, 34,000-L batches of treated LAW Feed are transferred from the Pretreatment Process to the LAW-Concentrate Receipt Vessels CRV and then to the Melter Feed Preparation Vessel (MFPV) where the waste is combined with glass former chemicals (GFC). The LAW Concentrate Storage Vessel in the Pretreatment Facility is not well mixed and may change composition as new waste feeds are added during processing. As such, waste and glass formers can not be moved past the LAW - MFPV until selected analytical results are available on the LAW - CRV sample. Each CRV batch is expected to refill an MFPV four times (or twice each for the two LAW MFPVs). The required analysis turnaround time is $<15$-hr with preferred turnaround time of $<8$-hr. Based on composition and radionuclide analyses, glass formulation calculations will specify the GFC batch to be added.

This restored work scope focused on developing an XRF method for AN-105, AP-101, AN-107 and AZ-101 simulants that are representative of the LAW envelopes. The simulant samples representing LAW envelopes were obtained from SRNL researchers (AN-105, AP-101, and AN-107) and from Optima Chemical Group (AZ-101). The simulant concentrations are listed in Table $1^{3,4}$. The hold point elements at the top of Table 1 (Al, $\mathrm{Cl}, \mathrm{K}, \mathrm{Na}$, and $\mathrm{SO}_{4}$ ) were given

\footnotetext{
${ }^{2}$ A. R. Jurgensen, D. M. Missimer, and F. M. Pennebaker, "Task Technical and Quality Assurance Plan for X-Ray Fluorescence Method Development”, WSRC-TR-2004-00563, Rev. 3, Savannah River Site, Aiken SC 29808 (June 13, 2007).

${ }^{3}$ C. A. Nash, M. R. Diugnan, and C. E. Duffey, "Batch, Kinetics, and Column Data from Spherical Resorcinol-Formaldehyde Resin", WSRC-STI-2006-00071, SRNL-RPP-2006-00024, Savannah River National Laboratory, Aiken SC 29808 (December 18, 2006).
} 
WSRC-STI-2007-00438

SRNL-RPP-2007-00020

primary attention because of their relative importance in glass batching and waste form compliance. Other elements that were given attention were $\mathrm{Ca}, \mathrm{PO}_{4}, \mathrm{Cr}, \mathrm{Ni}$, and $\mathrm{Mo}$. These ten elements were the main focus of the XRF WTP method development. These elements were proposed by Jurgensen in his report for LAW XRF calibration standards. The only element that is not included in the list compiled by Jurgensen was silicon. The standard vendor had difficulty keeping silicon in solution, so silicon was dropped from the standard matrices. The work scope of the activities did not include the characterization of the glass former feed nor glass product from the melter.

For Phase 1b, SRNL objectives were to:

- Re-install the XRF instrument in SRNL. When the funding was terminated back in April 2006, the instrument was moved to the Hydrogen Research Technical Laboratory (HRTL);

- Obtain LAW simulants from SRNL scientist for the three LAW Envelopes that were tested in phase 1a of this work;

- Perform additional precision testing

- Procure XRF matrix-matched standards; and

- Develop an XRF method.

${ }^{4}$ R. E. Eibling, R. F. Schumacher, and E. K. Hansen , "Development of Simulants to Support Mixing Tests for High Level Waste and Low Activity”, WSRC-TR-2003-00220, SRT-RPP-2003-00098, Savannah River Site, Aiken SC 29808 (December 2003). 
WSRC-STI-2007-00438

SRNL-RPP-2007-00020

Table 1. Reported Simulant Compositions.

\begin{tabular}{|c|c|c|c|c|}
\hline Component & $\begin{array}{c}\text { Envelope } \text { A }^{3} \\
\text { Tank AN-105 } \\
\text { Concentration } \\
\text { mg/L } \\
\end{array}$ & $\begin{array}{c}\text { Envelope } \mathbf{A}^{3} \\
\text { Tank AP-101 } \\
\text { Concentration } \\
\text { mg/L } \\
\end{array}$ & $\begin{array}{c}\text { Envelope B/D } \\
\text { Tank AZ-101 } \\
\text { Concentration } \\
\text { mg/L } \\
\end{array}$ & $\begin{array}{c}\text { Envelope } C^{3} \\
\text { Tank AN-107 } \\
\text { Concentration } \\
\text { mg/L } \\
\end{array}$ \\
\hline \multicolumn{5}{|l|}{ Hold Point Elements } \\
\hline Aluminum & 18560 & 6980 & $\mathrm{a}$ & 248 \\
\hline Chloride & $\mathrm{a}$ & 1450 & 121 & 1520 \\
\hline Potassium & 3506 & 27740 & 340 & 1250 \\
\hline Sodium & 115000 & 115000 & 9252 & 130000 \\
\hline Sulfate & 385 & 3580 & 406 & 5483 \\
\hline \multicolumn{5}{|l|}{ Non-Hold Point Elements } \\
\hline Calcium & $\mathrm{a}$ & 6.8 & $\mathrm{a}$ & 161 \\
\hline Iron & $\mathrm{a}$ & 2.2 & $\mathrm{a}$ & 11.4 \\
\hline Magnesium & $\mathrm{a}$ & $\mathrm{a}$ & $\mathrm{a}$ & $<1.56$ \\
\hline Phosphate & 266 & 1180 & 2341 & 883 \\
\hline Silicon & $\mathrm{a}$ & 122 & $\mathrm{a}$ & 56.5 \\
\hline Zinc & 5.6 & 5 & $\mathrm{a}$ & 20.7 \\
\hline Zirconium & $\mathrm{a}$ & $\mathrm{a}$ & $\mathrm{a}$ & a \\
\hline LDR Elements & & & $\mathrm{a}$ & \\
\hline Barium & $\mathrm{a}$ & 0.29 & $\mathrm{a}$ & $\mathrm{a}$ \\
\hline Cadmium & $\mathrm{a}$ & 1.7 & $\mathrm{a}$ & $<0.263$ \\
\hline Chromium & 631 & 150 & $\mathrm{a}$ & 0.506 \\
\hline Lead & 25 & 13 & $\mathrm{a}$ & $<2.74$ \\
\hline Nickel & $\mathrm{a}$ & 7 & $\mathrm{a}$ & 320 \\
\hline Selenium & $\mathrm{a}$ & $\mathrm{a}$ & $\mathrm{a}$ & $\mathrm{a}$ \\
\hline Silver & a & $\mathrm{a}$ & $\mathrm{a}$ & $\mathrm{a}$ \\
\hline \multicolumn{5}{|l|}{ Additional XRF Elements } \\
\hline Cerium & $\mathrm{a}$ & $\mathrm{a}$ & $\mathrm{a}$ & $<7.80$ \\
\hline Copper & $\mathrm{a}$ & 1.4 & $\mathrm{a}$ & 14.1 \\
\hline Lanthanum & $\mathrm{a}$ & $\mathrm{a}$ & $\mathrm{a}$ & $<1.46$ \\
\hline Manganese & $\mathrm{a}$ & $\mathrm{a}$ & $\mathrm{a}$ & 0.705 \\
\hline Molybdenum & 38 & 12.9 & $\mathrm{a}$ & 21.7 \\
\hline Neodymium & $\mathrm{a}$ & $\mathrm{a}$ & $\mathrm{a}$ & $<6.35$ \\
\hline \multicolumn{5}{|l|}{ Additional Constituents } \\
\hline Ammonium & $\mathrm{a}$ & $\mathrm{a}$ & $\mathrm{a}$ & $\mathrm{a}$ \\
\hline Boron & $\mathrm{a}$ & 14.2 & 15.7 & $\mathrm{a}$ \\
\hline Carbonate & $\mathrm{a}$ & 26760 & 3782 & $\mathrm{a}$ \\
\hline Fluoride & $\mathrm{a}$ & 53 & 68 & $\mathrm{a}$ \\
\hline Hydroxide & $\mathrm{a}$ & $\mathrm{a}$ & 2734 & $\mathrm{a}$ \\
\hline Nitrate & $\mathrm{a}$ & 104160 & 372 & 156600 \\
\hline Nitrite & $\mathrm{a}$ & 32500 & 1242 & 38500 \\
\hline Acetate & a & 1460 & 85 & $\mathrm{a}$ \\
\hline Citric Acid & $\mathrm{a}$ & $\mathrm{a}$ & $\mathrm{a}$ & $\mathrm{a}$ \\
\hline Ethylenediaminetetraacetic acid & $\mathrm{a}$ & $\mathrm{a}$ & $\mathrm{a}$ & $\mathrm{a}$ \\
\hline Formate & $\mathrm{a}$ & 1110 & $\mathrm{a}$ & $\mathrm{a}$ \\
\hline Glycolate & $\mathrm{a}$ & $\mathrm{a}$ & $\mathrm{a}$ & $\mathrm{a}$ \\
\hline n-Hydroxyethylenediaminetriacetic acid & $\mathrm{a}$ & $\mathrm{a}$ & $\mathrm{a}$ & $\mathrm{a}$ \\
\hline Iminodiacetic Acid & $\mathrm{a}$ & $\mathrm{a}$ & $\mathrm{a}$ & $\mathrm{a}$ \\
\hline Nitrilotriacetic Acid & $\mathrm{a}$ & $\mathrm{a}$ & $\mathrm{a}$ & $\mathrm{a}$ \\
\hline Oxalate & $\mathrm{a}$ & 1600 & $\mathrm{a}$ & $<1000$ \\
\hline Sodium Gluconate & $\mathrm{a}$ & $\mathrm{a}$ & $\mathrm{a}$ & $\mathrm{a}$ \\
\hline
\end{tabular}

a) These constituents were not reported in references 3 or 4 . 
WSRC-STI-2007-00438

SRNL-RPP-2007-00020

\section{Experimental}

\subsection{Instrumentation}

\subsubsection{Re-Installing the XRF Instrument}

The Rigaku Mini II XRF instrument was moved to the HRTL after WTP issued the stop work on Phase $1 \mathrm{~b}$ activities in April 2006. The instrument was setup except for the P-10 cylinder and helium service. However at the start of the revised work scope, the XRF instrument was moved back to SRNL because of the problems with the in-house gas delivery system. A free software upgrade was available through Rigaku/MSC's FTTP website. Prior to the start of the upgrade, all the information that was stored on the computer was saved and reloaded after the upgrade was complete. This process of saving and reloading information in the software is carried out through a subroutine in the software called DSAVE/DLOAD.

Note: The DSAVE/DLOAD subroutine should be carried out at least once a week and the information stored on floppy disks or on a file server. The new version of the software will allow the user to store data directly to a file server.

\subsubsection{Start-Up}

After the P-10, 10\% methane 90\% argon, and helium (ultra pure 99.999\%) gas lines were connected to the wavelength dispersive X-ray fluorescence instrument (WD-XRF), the 4- $\mu \mathrm{m}$ instrument film, Ultralene ${ }^{\mathrm{TM}}$, was replaced. Initially, the flow rate for the P-10 and helium were set to $50 \mathrm{~mL} / \mathrm{min}$ and $2 \mathrm{~L} / \mathrm{min}$ respectively. The P-10 gas was set at a flow rate of 50 $\mathrm{mL} / \mathrm{min}$ for 30 minutes to purge the gas flow proportional detector then maintained at 25 $\mathrm{mL} / \mathrm{min}$. This adjustment to the P-10 gas should be done initially and after changing out the $\mathrm{P}-10$ cylinder. The P-10 and helium gases were allowed to flow through the instrument for one hour before the main power was turned on. The system was initialized and the x-ray tube turned on through the software. The voltage, $\mathrm{kV}$, and current, $\mathrm{mA}$, settings for the $\mathrm{x}$-ray tube were incremented slowly over a 30 minute time period until the x-ray tube was at full power, $40-\mathrm{kV} 1.2-\mathrm{mA}$. The instrument was left at full power with the helium flowing overnight for stability purposes.

\subsubsection{Performance Check}

Instrument performance was confirmed by running a vendor supplied pulse height adjustment (PHA) sample and a waste compliance program (WCP) Blend glass. Both tests were done at full power in helium. The PHA sample verifies functionality of both detectors, flow proportional counter (PC) and the scintillation detector (SC). The scan of the flow proportional counter, Figure 1, looks at $\mathrm{Si} \mathrm{K \alpha}$ on the PET crystal. The scan of the scintillation detector, Figure 2, looks at the Sn K $\alpha$ on the LIF1 crystal. The peak position for the flow proportional counter and the scintillation detector should be around 200 . The resolution for the flow proportional counter and the scintillation detector should be $<35 \%$ and $<40 \%$ 
WSRC-STI-2007-00438

SRNL-RPP-2007-00020

respectively. The WCP Blend Glass was run to ensure that the crystals were not bumped in transit from one building to the other and to determine if the $\mathrm{x}$-ray tube is deteriorating. The model for this test looks at three elemental intensities, $\mathrm{Al}, \mathrm{Na}$, and $\mathrm{Fe}$, on the three different crystals, PET, RX35, and LIF1. By monitoring these elements intensities, one can determine if the crystals need to be aligned or if the X-ray tube needs to be replaced. Both tests should be done on a monthly basis or earlier if a problem is detected. 
WSRC-STI-2007-00438

SRNL-RPP-2007-00020

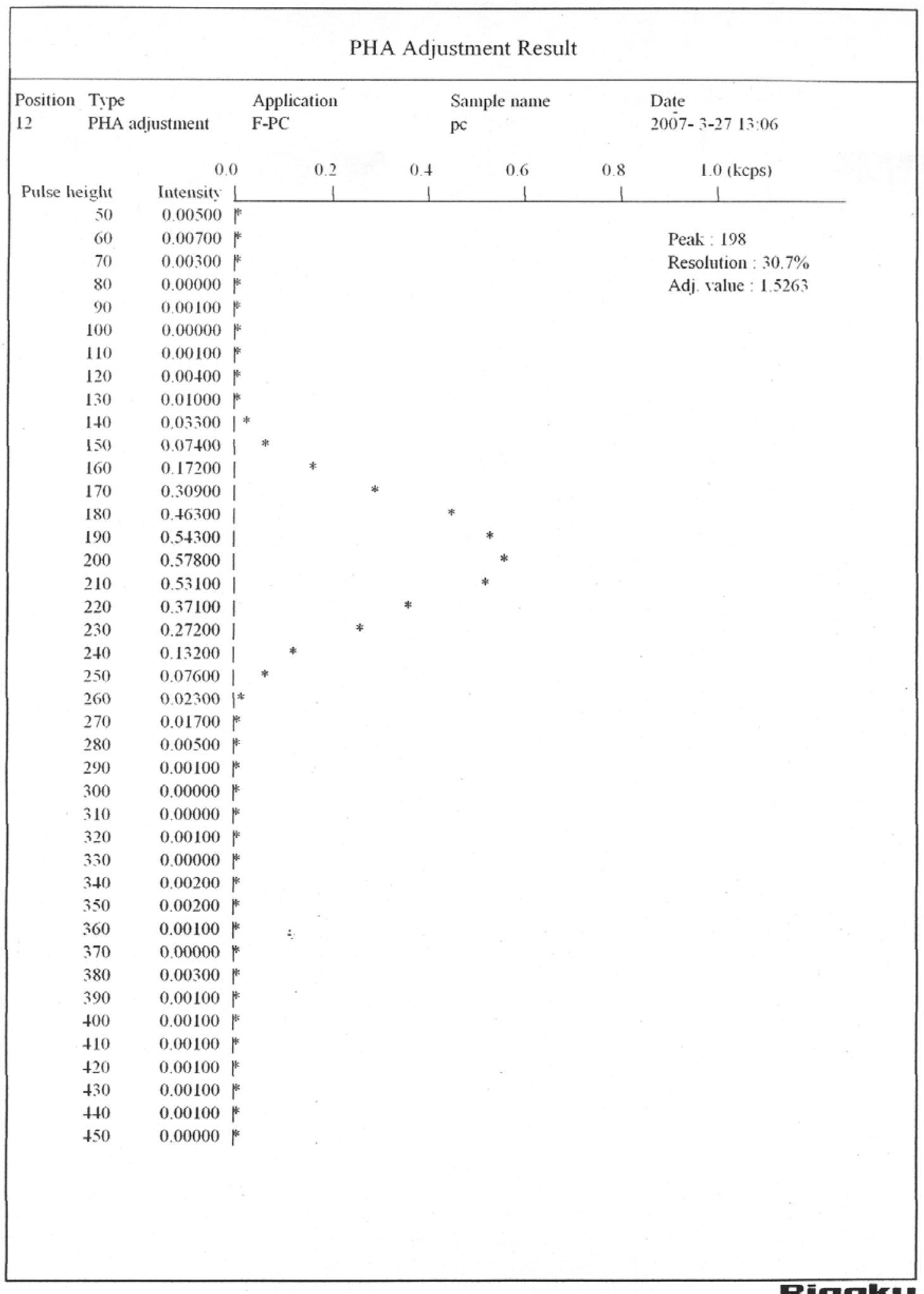

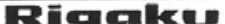

Figure 1. PHA scan for the flow proportional counter. 
WSRC-STI-2007-00438

SRNL-RPP-2007-00020

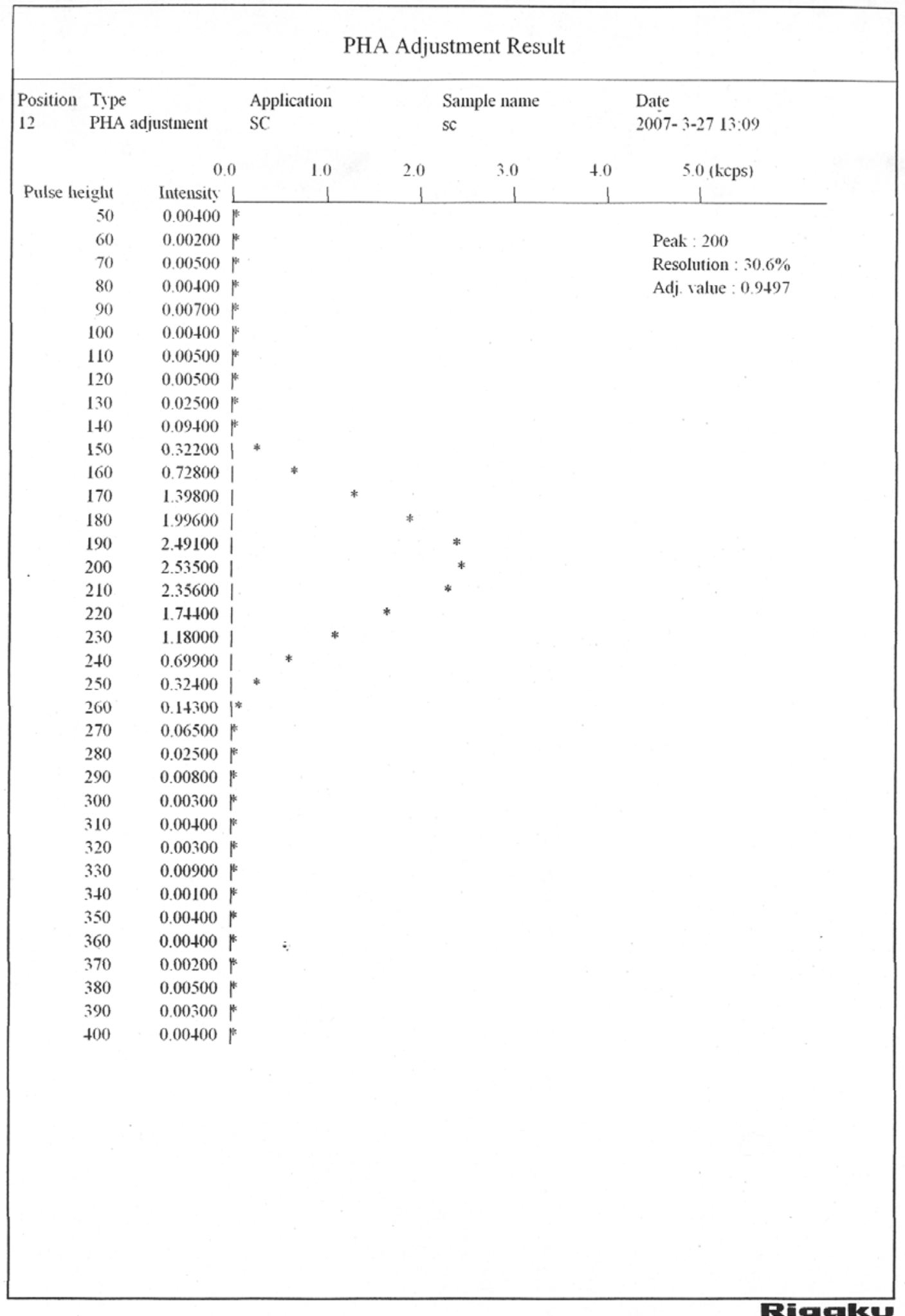

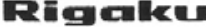

Figure 2. PHA scan for the scintillation detector. 
WSRC-STI-2007-00438

SRNL-RPP-2007-00020

\subsubsection{Verification of Standards/Simulants}

The five standards and the four simulants were analyzed on a Perkin Elmer Optima 3000 ICP-AES and a Dionex DX-500 IC to independently verify concentrations. The High Purity standards are as follows:

- AY-102 (Standard A)

- AP-101 (Standard B)

- AZ-101 (Standard C)

- AZ-102 (Standard D)

- AP-103 (Standard E).

The simulants are listed in Section 3.2.

\subsection{Simulants}

The LAW simulants that were prepared and used in Phase 1a and the start of Phase 1b activities of this task were neutralized and discarded when WTP issued a notice to discontinue the remaining work scope in April 2006. Instead of preparing new LAW simulants for this restored WTP XRF work scope, SRNL obtained simulant samples representative of LAW envelopes from Charles Nash of the Separations Science Programs group and Dan Burns of the Process Science and Engineering section of SRNL.

- AN-105 Envelope A simulant,

- AP-101 Envelope A simulant,

- AN-107 Envelope C simulant.

- AZ-101 Envelope B/D simulant.

Envelope A simulants, AN-105 and AP-101, had been prepared using the Russ Eibling recipe ${ }^{5}$. The Envelope A, AN-105, simulant was obtained after the $5 \mathrm{M}$ sodium dilution ${ }^{3}$. Envelope $\mathrm{C}$ simulant, AN-107, was produced by a strontium/TRU precipitation after caustic adjustment ${ }^{4}$. AZ-101 Envelope B/D simulant was prepared by Optima Chemical Group of Douglas, Georgia for the Gas Release/Holdup Testing currently being performed by SRNL and Pacific Northwest National Laboratory (PNNL). Optima Chemical Group prepared the simulant using the Eibling recipe that was provided to them. The AZ-101 simulant was a combination of sludge and supernate which was centrifuged with a Fisher Scientific Marathon $21 \mathrm{~K}$ centrifuge set for 2-hr at $3000 \mathrm{rpm}$ to remove the majority of suspended material. Table 2 contains the concentrations for $\mathrm{Al}, \mathrm{Ca}, \mathrm{Cr}, \mathrm{Mo}, \mathrm{Ni}, \mathrm{K}, \mathrm{Na}, \mathrm{Cl}, \mathrm{SO}_{4}$, and $\mathrm{PO}_{4}$ in the simulants representative of the LAW envelopes after any dilutions and/or treatments.

\footnotetext{
${ }^{5}$ R. E. Eibling and C. A. Nash, "Hanford Waste Simulants Created for Research and Development on the River Protection Project-Waste Treatment Plant", WSRC-TR-2000-00338, Rev. 0, Appendix A, Savannah River Site, Aiken SC 29808 (February, 2001)
} 
WSRC-STI-2007-00438

SRNL-RPP-2007-00020

Table 2. Major Element Concentrations in RPP Simulants.

\begin{tabular}{cccccc}
\hline \hline Element & Units & AN-105 $^{1}$ & AP-101 & AZ-101 $^{2}$ & AN-107 $^{3}$ \\
\hline \hline $\mathbf{A l}$ & $\mathrm{mg} / \mathrm{L}$ & 18560 & 6980 & $\mathrm{a}$ & 248 \\
$\mathbf{C a}$ & $\mathrm{mg} / \mathrm{L}$ & $\mathrm{a}$ & 6.8 & $\mathrm{a}$ & 161 \\
$\mathbf{C r}$ & $\mathrm{mg} / \mathrm{L}$ & 631 & 150 & $\mathrm{a}$ & 0.506 \\
$\mathbf{K}$ & $\mathrm{mg} / \mathrm{L}$ & 3506 & 27740 & 340 & 1250 \\
$\mathbf{M o}$ & $\mathrm{mg} / \mathrm{L}$ & 38 & 12.9 & $\mathrm{a}$ & 21.7 \\
$\mathbf{N a}$ & $\mathrm{mg} / \mathrm{L}$ & 115000 & 115000 & 9252 & 130000 \\
$\mathbf{N i}$ & $\mathrm{mg} / \mathrm{L}$ & $\mathrm{a}$ & 7.0 & $\mathrm{a}$ & 320 \\
$\mathbf{S}\left(\right.$ also measured as $\left.\mathbf{S O}_{4}\right)$ & $\mathrm{mg} / \mathrm{L}$ & 385 & 3580 & 406 & 5483 \\
$\mathbf{P}\left(\right.$ also measured as $\mathbf{P O}_{4}$ ) & $\mathrm{mg} / \mathrm{L}$ & 266 & 1180 & 2341 & 883 \\
$\mathbf{C l}$ & $\mathrm{mg} / \mathrm{L}$ & $\mathrm{a}$ & 1450 & 121 & 1520 \\
\hline
\end{tabular}

${ }^{1}$ Simulant $\mathrm{AN}-105$ was made by the full Eibling recipe and diluted to $5 \mathrm{M}$ sodium.

${ }^{2}$ Envelope B/D.

${ }^{3}$ Simulant AN-107 was produced by a stronium/TRU precipitation after caustic adjustment.

a) These elements were not listed in the reports.

All the simulants were filtered through a Corning $0.2-\mu \mathrm{m}$ cellulose nitrate filter assembly and stored in Teflon bottles. The metals in the filtrates were analyzed by ICP-AES and inorganic anions by IC. Many of the constituents in the solutions, e.g. organics, can not be determined by XRF and were not analyzed. Use of these simulants was approved by WTP on 6/21/07, as defined in SRNL-RPP-2004-00091 Rev 3. (See Appendix A)

\subsubsection{Envelope A}

Envelope A waste was generated by evaporating the low organic content, waste supernates stored in single shell tanks and the supernate produced by the Hanford B plant. Envelope A can be generally characterized as an alkaline $([\mathrm{OH}]>1 \mathrm{M})$, high sodium $(>8 \mathrm{M})$ supernate. Envelope A tanks contains ${ }^{137} \mathrm{Cs}$ at concentrations that require removal prior to LAW vitrification. The majority of the LAW vitrified product in the initial phase of the RPP-WTP will be Envelope A.

Envelope A simulants were based on the supernates from Tank AN-105 and Tank AP-101, which was decanted from the solids within the waste tank. The simulant concentrations used for AN-105 and AP-101 are listed in the first two columns of Table 1 or 2. These concentrations were reported in Appendix A in WSRC-STI-2006-00071, SRNL-RPP-2006-00024.

Envelope A simulants, AN-105 and AP-101 were analyzed by ICP-AES and IC. The average values for the ICP-AES and IC are listed in Tables 3 and 4. The ICP-AES values are an average of ten runs that were run on different days with different calibrations. The IC values are an average of five runs that were run on different days with different calibrations. IC did not report a phosphate value because of matrix effects. All the detectable components for the ICP-AES and IC can be found in Appendix F. The average values given in Tables 3 and 4 will 
WSRC-STI-2007-00438

SRNL-RPP-2007-00020

be compared to the XRF results.

Table 3. Analytical Results for AN-105 Simulant.

\begin{tabular}{|c|c|c|c|}
\hline Element & Units & $\begin{array}{c}\text { Measured } \\
\text { ICP-AES } \\
\text { Perkin Elmer }\end{array}$ & $\begin{array}{c}\text { Measured } \\
\text { IC } \\
\text { Dionex }\end{array}$ \\
\hline Al & $\mathrm{mg} / \mathrm{L}$ & 10600 & $\mathrm{a}$ \\
\hline Ca & $\mathrm{mg} / \mathrm{L}$ & $<1.29$ & a \\
\hline Cr & $\mathrm{mg} / \mathrm{L}$ & 640 & a \\
\hline $\mathbf{K}$ & $\mathrm{mg} / \mathrm{L}$ & 3770 & a \\
\hline Mo & $\mathrm{mg} / \mathrm{L}$ & 39.8 & a \\
\hline $\mathbf{N a}$ & $\mathrm{mg} / \mathrm{L}$ & 122000 & $\mathrm{a}$ \\
\hline $\mathbf{N i}$ & $\mathrm{mg} / \mathrm{L}$ & $<0.35$ & $\mathrm{a}$ \\
\hline $\mathrm{S}$ (also measured as $\mathrm{SO}_{4}$ ) & $\mathrm{mg} / \mathrm{L}$ & 398 & 140 \\
\hline $\mathrm{P}$ (also measured as $\mathrm{PO}_{4}$ ) & $\mathrm{mg} / \mathrm{L}$ & 289 & $\mathrm{~b}$ \\
\hline $\mathrm{Cl}$ & $\mathrm{mg} / \mathrm{L}$ & $\mathrm{a}$ & 4600 \\
\hline
\end{tabular}

a) These elements could not be measured by the given method.

b) Because of martix effects, $\mathrm{PO}_{4}{ }^{2-}$ was not reported.

Table 4. Analytical Results for AP-101 Simulant.

\begin{tabular}{|c|c|c|c|}
\hline Element & Units & $\begin{array}{c}\text { Measured } \\
\text { ICP-AES } \\
\text { Perkin Elmer } \\
\end{array}$ & $\begin{array}{c}\text { Measured } \\
\text { IC } \\
\text { Dionex } \\
\end{array}$ \\
\hline Al & $\mathrm{mg} / \mathrm{L}$ & 6850 & $\mathrm{a}$ \\
\hline Ca & $\mathrm{mg} / \mathrm{L}$ & $<1.29$ & $\mathrm{a}$ \\
\hline $\mathrm{Cr}$ & $\mathrm{mg} / \mathrm{L}$ & 152 & $\mathrm{a}$ \\
\hline $\mathbf{K}$ & $\mathrm{mg} / \mathrm{L}$ & 28200 & $a$ \\
\hline Mo & $\mathrm{mg} / \mathrm{L}$ & 13.6 & $\mathrm{a}$ \\
\hline $\mathbf{N a}$ & $\mathrm{mg} / \mathrm{L}$ & 120000 & $\mathrm{a}$ \\
\hline $\mathrm{Ni}$ & $\mathrm{mg} / \mathrm{L}$ & $<0.35$ & $\mathrm{a}$ \\
\hline $\mathrm{S}$ (also measured as $\mathrm{SO}_{4}$ ) & $\mathrm{mg} / \mathrm{L}$ & 3810 & 3450 \\
\hline $\mathrm{P}$ (also measured as $\mathrm{PO}_{4}$ ) & $\mathrm{mg} / \mathrm{L}$ & 1210 & $\mathrm{~b}$ \\
\hline Cl & $\mathrm{mg} / \mathrm{L}$ & $\mathrm{a}$ & 1490 \\
\hline
\end{tabular}

a) These elements could not be measured by the given method.

b) Because of martix effects, $\mathrm{PO}_{4}{ }^{2-}$ was not reported.

\subsubsection{Envelope C}

Envelope $\mathrm{C}$ waste was produced from evaporation of wastes derived from high organic content single-shell tank waste and waste generated during the $\mathrm{Cs} / \mathrm{Sr}$ separation and encapsulation process conducted at the Hanford B plant. The waste is characterized by the high organic carbon content because of the presence of organic complexing agents and their decomposition products. Due to the complexing agents, the concentration of ${ }^{90} \mathrm{Sr}$ and TRU will require 
WSRC-STI-2007-00438

SRNL-RPP-2007-00020

removal using the Sr/TRU precipitation and filtration process. Removal of ${ }^{137} \mathrm{Cs}$ by ion exchange will also be required.

The simulant concentration for AN-107 is listed in the last column of Table 1 and 2. This concentration was reported in Appendix A in WSRC-STI-2006-00071, SRNL-RPP-2006-00024. ${ }^{3}$

Envelope C simulant, AN-107 was analyzed by ICP-AES and IC. The average values for the ICP-AES and IC are listed in Table 5. All the detectable components for the ICP-AES and IC can be found in Appendix F. The average values given in Table 5 will be compared to the XRF results.

Table 5. Analytical Results for AN-107 Simulant.

\begin{tabular}{|c|c|c|c|}
\hline Element & Units & $\begin{array}{c}\text { Measured } \\
\text { ICP-AES } \\
\text { Perkin Elmer }\end{array}$ & $\begin{array}{c}\text { Measured } \\
\text { IC } \\
\text { Dionex }\end{array}$ \\
\hline Al & $\mathrm{mg} / \mathrm{L}$ & 236 & a \\
\hline Ca & $\mathrm{mg} / \mathrm{L}$ & 145 & a \\
\hline $\mathrm{Cr}$ & $\mathrm{mg} / \mathrm{L}$ & 0.643 & a \\
\hline $\mathbf{K}$ & $\mathrm{mg} / \mathrm{L}$ & 1200 & a \\
\hline Mo & $\mathrm{mg} / \mathrm{L}$ & 21.8 & $\mathrm{a}$ \\
\hline $\mathbf{N a}$ & $\mathrm{mg} / \mathrm{L}$ & 141000 & a \\
\hline $\mathbf{N i}$ & $\mathrm{mg} / \mathrm{L}$ & 301 & a \\
\hline $\mathrm{S}$ (also measured as $\mathrm{SO}_{4}$ ) & $\mathrm{mg} / \mathrm{L}$ & 5200 & 4710 \\
\hline $\mathrm{P}$ (also measured as $\mathrm{PO}_{4}$ ) & $\mathrm{mg} / \mathrm{L}$ & 894 & $\mathrm{~b}$ \\
\hline Cl & $\mathrm{mg} / \mathrm{L}$ & $\mathrm{a}$ & 1500 \\
\hline
\end{tabular}

a) These elements could not be measured by the given method.

b) Because of martix effects, $\mathrm{PO}_{4}{ }^{2-}$ was not reported.

\subsubsection{Envelope B/D}

Envelope B/D is comprised of insoluble compounds referred to as sludge, primarily insoluble transition metal hydroxides with most of the long half- life radionuclides, slurried with the supernate from the same tank. For example, the slurry from tank 241-AZ-101 would be comprised of the B envelope supernate and D envelope sludge. The D envelope waste will require washing using crossflow filtration and possibly caustic leaching to meet glass specifications.

The simulant concentration for AZ-101 is listed in the third column of Table 1 or 2 . This concentration was reported on page 46 of WSRC-TR-2003-000220, SRT-RPP-2003-00098. The directions of how Optima Chemical Group prepared the simulant can be found in Appendix F of WSRC-TR-2003-00220, SRT-RPP-2003-00098.

Envelope B/D simulant, AZ-101 was analyzed by ICP-AES and IC. The average values for 
WSRC-STI-2007-00438

SRNL-RPP-2007-00020

the ICP-AES and IC are listed in Table 6. All the detectable components for the ICP-AES and IC can be found in Appendix F. The average values given in Table 6 will be compared to the XRF results.

Table 6. Analytical Results for AZ-101 Simulant.

\begin{tabular}{|c|c|c|c|}
\hline Element & Units & $\begin{array}{c}\text { Measured } \\
\text { ICP-AES } \\
\text { Perkin Elmer }\end{array}$ & $\begin{array}{c}\text { Measured } \\
\text { IC } \\
\text { Dionex } \\
\end{array}$ \\
\hline Al & $\mathrm{mg} / \mathrm{L}$ & $<2.56$ & $\mathrm{a}$ \\
\hline Ca & $\mathrm{mg} / \mathrm{L}$ & $<1.29$ & a \\
\hline $\mathrm{Cr}$ & $\mathrm{mg} / \mathrm{L}$ & 142 & $\mathrm{a}$ \\
\hline $\mathbf{K}$ & $\mathrm{mg} / \mathrm{L}$ & 781 & a \\
\hline Mo & $\mathrm{mg} / \mathrm{L}$ & 25.5 & a \\
\hline $\mathrm{Na}$ & $\mathrm{mg} / \mathrm{L}$ & 11500 & a \\
\hline $\mathbf{N i}$ & $\mathrm{mg} / \mathrm{L}$ & $<0.349$ & $\mathrm{a}$ \\
\hline $\mathrm{S}$ (also measured as $\mathrm{SO}_{4}$ ) & $\mathrm{mg} / \mathrm{L}$ & 800 & 748 \\
\hline $\mathrm{P}$ (also measured as $\mathrm{PO}_{4}$ ) & $\mathrm{mg} / \mathrm{L}$ & $<60$ & $\mathrm{~b}$ \\
\hline Cl & $\mathrm{mg} / \mathrm{L}$ & $\mathrm{a}$ & 259 \\
\hline
\end{tabular}

a) These elements were not measured by the given method.

b) Because of martix effects, $\mathrm{PO}_{4}{ }^{2-}$ was not reported.

\subsection{Standards}

SRNL consulted with WTP about the standards to calibrate the XRF instrument because no standards existed for the LAW. SRNL and WTP decided to have an offsite vendor prepare and certify a set of standards that covered the anticipated CRV major element concentration from the first five processed LAW tanks: AY-102, AP-101, AZ-101, AZ-102, and AP-103. SRNL selected High Purity Standards from Charleston, South Carolina to prepare the standards. Table 7 lists the elements and concentrations for each of the LAW waste tanks mentioned above. The concentration for each element in the LAW waste tanks came from the most current available Best Basis Inventory obtained from the TWINS website. The standards were labeled A through E for tanks AY-102, AP-101, AZ-101, AZ-102, and AP-103. SRNL requested the Certificates of Analysis and the Material Data Safety Sheets (MSDS) for each of the standards. Standard A, AY-102, was made from a different lot of starting materials from the other four standards. Standards were prepared in $4 \% \mathrm{HNO}_{3}$ at half the targeted concentrations (see Table 7) without silicon due to precipitation problems during preparation. Standard D was prepared at the target concentration. Table 8 lists the final concentration for each element in the standards. (See Appendix B for the Standard Certificates of Analysis and the MSDS information) 
Table 7. Target Calibration Standard Concentrations.

\begin{tabular}{|c|c|c|c|c|c|}
\hline Element & $\begin{array}{c}\text { Standard A } \\
\text { AY-102 } \\
\mu \mathrm{g} / \mathrm{mL}\end{array}$ & $\begin{array}{c}\text { Standard B } \\
\text { AP-101 } \\
\mu \mathrm{g} / \mathrm{mL}\end{array}$ & $\begin{array}{c}\text { Standard C } \\
\text { AZ-101 } \\
\mu \mathrm{g} / \mathrm{mL}\end{array}$ & $\begin{array}{c}\text { Standard D } \\
\text { AZ-102 } \\
\mu \mathrm{g} / \mathrm{mL}\end{array}$ & $\begin{array}{c}\text { Standard E } \\
\text { AP-103 } \\
\mu \mathrm{g} / \mathrm{mL}\end{array}$ \\
\hline Aluminum & 17700 & 7300 & $\begin{array}{l}19000 \\
\end{array}$ & 9600 & $\begin{array}{ll}18300 \\
\end{array}$ \\
\hline Calcium & 1000 & 10 & 250 & 400 & 80 \\
\hline Chromium & 500 & 170 & 800 & 900 & 600 \\
\hline Molybdenum & 10 & 20 & 100 & 60 & 60 \\
\hline Nickel & 750 & 10 & 260 & 750 & 80 \\
\hline Potassium & 450 & 34000 & 4800 & 3400 & 6500 \\
\hline Silicon & 2800 & 100 & 450 & 560 & 100 \\
\hline Sodium & 73000 & 129000 & 124000 & 65800 & 178000 \\
\hline Chloride & 100 & 1600 & 270 & 70 & 4300 \\
\hline Phosphate & 4900 & 1300 & 2100 & 750 & 2400 \\
\hline Sulfate & 1800 & 3900 & 19300 & 19000 & 4800 \\
\hline \multicolumn{6}{|c|}{$\begin{array}{l}\text { * Standard A, Best Basis Inventory, Tank 241-AY-102, FY06, Q1. } \\
\text { * Standard B, Best Basis Inventory, Tank 241-AP-101, FY05, Q2. } \\
\text { * Standard C, Best Basis Inventory, Tank 241-AZ-101, FY06, Q1. } \\
\text { * Standard D, Best Basis Inventory, Tank 241-AP-103, FY05, Q1. }\end{array}$} \\
\hline
\end{tabular}

Table 8. High Purity Calibration Standard Concentrations.

\begin{tabular}{cccccc}
\hline \hline & $\begin{array}{c}\text { Standard A } \\
\text { AY-102 } \\
\boldsymbol{\mu g} / \mathbf{m L}\end{array}$ & $\begin{array}{c}\text { Standard B } \\
\mathbf{A P - 1 0 1} \\
\boldsymbol{\mu g} / \mathbf{m L}\end{array}$ & $\begin{array}{c}\text { Standard C } \\
\mathbf{A Z - 1 0 1} \\
\boldsymbol{\mu g} / \mathbf{m L}\end{array}$ & $\begin{array}{c}\text { Standard D } \\
\text { AZ-102 } \\
\boldsymbol{\mu g} / \mathbf{m L}\end{array}$ & $\begin{array}{c}\text { Standard E } \\
\text { AP-103 } \\
\boldsymbol{\mu g} / \mathbf{m L}\end{array}$ \\
\hline \hline Aluminum & 8850 & 3650 & 9500 & 9600 & 9150 \\
\hline Calcium & 500 & 5 & 125 & 400 & 40 \\
\hline Chromium & 250 & 85 & 400 & 900 & 300 \\
\hline Molybdenum & 5 & 10 & 50 & 60 & 30 \\
\hline Nickel & 375 & 5 & 130 & 750 & 40 \\
\hline Potassium & 225 & 17000 & 2400 & 3400 & 3250 \\
\hline Sodium & 36500 & 64500 & 62000 & 65800 & 89000 \\
\hline Chloride & 50 & 800 & 135 & 70 & 2150 \\
\hline Phosphate & 2450 & 650 & 1050 & 750 & 1200 \\
\hline Sulfate & 900 & 1950 & 9650 & 19000 & 2400 \\
\hline \hline
\end{tabular}

The ICP-AES analyzed the five High Purity standards on ten different days using a new calibration curve each day, whereas the IC ran the standards on five different days using five different calibrations. Table 9 shows the averages of the runs for each of the different High Purity standards. All the results from the IC and ICP-AES for the standards can be found in Appendix F. Because of matrix effects, the phosphate value was not reported on the IC. The sulfate value was reported, but the value is 2 to 5 times higher than expected. The sulfate could be plagued by the same matrix effect as the phosphate. This matrix effect on sulfate in the IC 
WSRC-STI-2007-00438

SRNL-RPP-2007-00020

data only showed up in the procured High Purity standards, which were made up in $4 \% \mathrm{HNO}_{3}$, but not in the basic simulants.

Table 9. ICP-AES and IC Average Concentrations for the High Purity Standards.

\begin{tabular}{|c|c|c|c|c|c|c|}
\hline Element & $\begin{array}{c}\text { Standard A } \\
\text { Certificate } \\
\mu \mathrm{g} / \mathrm{mL}\end{array}$ & $\begin{array}{c}\text { Standard A } \\
\text { ICP Average }^{1} \\
\mu \mathrm{g} / \mathrm{mL}\end{array}$ & $\begin{array}{c}\text { Standard A } \\
\text { IC Average }^{2} \\
\mu \mathrm{g} / \mathrm{mL}\end{array}$ & $\begin{array}{c}\text { Standard B } \\
\text { Certificate } \\
\mu \mathrm{g} / \mathrm{mL}\end{array}$ & $\begin{array}{c}\text { Standard B } \\
\text { ICP Average }^{1} \\
\mu \mathrm{g} / \mathrm{mL}\end{array}$ & $\begin{array}{c}\text { Standard B } \\
\text { IC Average }^{2} \\
\mu \mathrm{g} / \mathrm{mL}\end{array}$ \\
\hline Al & 8850 & 8700 & $\bar{a}$ & 3650 & 3560 & $\bar{a}$ \\
\hline Ca & 500 & 495 & $\mathrm{a}$ & 5 & 4.8 & a \\
\hline $\mathrm{Cr}$ & 250 & 253 & $\mathrm{a}$ & 85 & 84.2 & a \\
\hline Mo & 5 & 5.5 & a & 10 & 10.1 & a \\
\hline $\mathrm{Ni}$ & 375 & 374 & a & 5 & 4.9 & a \\
\hline $\mathbf{K}$ & 225 & 230 & $\mathrm{a}$ & 17000 & 17000 & a \\
\hline $\mathrm{Na}$ & 36500 & 36800 & $\mathrm{a}$ & 64500 & 64800 & a \\
\hline $\mathrm{S}$ (also measured as $\mathrm{SO}_{4}$ ) & 900 & 952 & 3560 & 1950 & 2030 & 7160 \\
\hline $\mathrm{P}$ (also measured as $\mathrm{PO}_{4}$ ) & 2450 & 2320 & $\mathrm{~b}$ & 650 & 615 & $\mathrm{~b}$ \\
\hline Cl & 50 & $\mathrm{a}$ & $<100$ & 800 & $\mathrm{a}$ & 848 \\
\hline & Standard C & Standard C & Standard C & Standard D & Standard D & Standard D \\
\hline Element & $\begin{array}{c}\text { Certificate } \\
\mu \mathrm{g} / \mathrm{mL}\end{array}$ & $\begin{array}{c}\text { ICP Average }^{1} \\
\mu \mathrm{g} / \mathrm{mL}\end{array}$ & $\begin{array}{c}\text { IC Average }^{2} \\
\mu \mathrm{g} / \mathrm{mL}\end{array}$ & $\begin{array}{c}\text { Certificate } \\
\mu \mathrm{g} / \mathrm{mL}\end{array}$ & $\begin{array}{c}\text { ICP Average }^{1} \\
\mu \mathrm{g} / \mathrm{mL}\end{array}$ & $\begin{array}{c}\text { IC Average }^{2} \\
\mu \mathrm{g} / \mathrm{mL}\end{array}$ \\
\hline Al & 9500 & 9270 & $\mathrm{a}$ & 9600 & 9490 & $\mathrm{a}$ \\
\hline Ca & 125 & 124 & a & 400 & 400 & a \\
\hline $\mathrm{Cr}$ & 400 & 391 & $\mathrm{a}$ & 900 & 893 & a \\
\hline Mo & 50 & 49.7 & $\mathrm{a}$ & 60 & 60.8 & a \\
\hline $\mathbf{N i}$ & 130 & 126 & $\mathrm{a}$ & 750 & 737 & a \\
\hline $\mathbf{K}$ & 2400 & 2440 & $\mathrm{a}$ & 3400 & 3430 & a \\
\hline $\mathrm{Na}$ & 62000 & 62200 & $\mathrm{a}$ & 65800 & 67300 & $\mathrm{a}$ \\
\hline $\mathrm{S}$ (also measured as $\mathrm{SO}_{4}$ ) & 9650 & 9980 & 24800 & 19000 & 19900 & 41600 \\
\hline $\mathrm{P}$ (also measured as $\mathrm{PO}_{4}$ ) & 1050 & 983 & $\mathrm{~b}$ & 750 & 720 & $\mathrm{~b}$ \\
\hline Cl & 135 & $\mathrm{a}$ & 182 & 70 & $\mathrm{a}$ & 134 \\
\hline
\end{tabular}

\begin{tabular}{cccc}
\hline \hline Element & $\begin{array}{c}\text { Standard E } \\
\text { Certificate } \\
\boldsymbol{\mu g} / \mathbf{m L}\end{array}$ & $\begin{array}{c}\text { Standard E } \\
\text { ICP Average } \\
\boldsymbol{\mu g} / \mathbf{m L}\end{array}$ & $\begin{array}{c}\text { Standard E } \\
\text { IC Average }^{2} \\
\boldsymbol{\mu g} / \mathbf{m L}\end{array}$ \\
\hline \hline $\mathbf{A l}$ & 9150 & 9000 & $\mathrm{a}$ \\
$\mathbf{C a}$ & 40 & 38.5 & $\mathrm{a}$ \\
$\mathbf{C r}$ & 300 & 290 & $\mathrm{a}$ \\
$\mathbf{M o}$ & 30 & 29.6 & $\mathrm{a}$ \\
$\mathbf{N i}$ & 40 & 38.1 & $\mathrm{a}$ \\
$\mathbf{K}$ & 3250 & 3300 & $\mathrm{a}$ \\
$\mathbf{N a}$ & 89000 & 90000 & $\mathrm{a}$ \\
$\mathbf{C l}$ & 2400 & 2460 & 10900 \\
$\mathbf{P}$ (also measured as $\mathbf{S O}_{\mathbf{4}}$ ) & 1200 & 1110 & $\mathrm{~b}$ \\
(also measured as $\mathbf{P O}_{\mathbf{4}}$ ) & 2150 & $\mathrm{a}$ & 2100 \\
\hline \hline
\end{tabular}

${ }^{1}$ An average of 10 runs

${ }^{2}$ An average of 5 runs.

a) These elements could not be measured by the given method.

b) Because of matrix effects, $\mathrm{PO}_{4}{ }^{2-}$ was not reported.

Note: High bias with IC results for $\mathrm{SO} 4$ and $\mathrm{PO} 4$ due to matrix interferences. 
WSRC-STI-2007-00438

SRNL-RPP-2007-00020

\subsection{Precision}

The precision of the simulants representative of LAW envelopes was repeated in this work to confirm that the instrument was operating properly after being moved to and from HRTL, and to resolve the sample stability problem.

For the simulant precision analysis seven separate tests were conducted:

Test 1 . Triplicate analysis of ten filtered undiluted AN-105 simulant solutions in fixed autosampler positions previously reported in WSRC-TR-2006-00137, SRNL-RPP-2006-00019. (See Appendix C Table C-1)

Test 2. Triplicate analysis of five filtered diluted AN-105 simulant (1:1) solutions in fixed autosampler positions. (See Appendix C Table C-2)

Test 3. Fourteen analysis of one filtered diluted AN-105 simulant solution (1:1) in fixed autosampler position over 8 hours. (See Appendix C Table C-3)

Test 4. Five analysis of one filtered diluted AN-105 simulant solution (1:1) in fixed autosampler position run at different times during the day. (See Appendix C Table C-4)

Test 5. Triplicate analysis of five filtered diluted AN-105 simulant (1:1) solutions in fixed autosampler positions with the instrument film was replaced prior to each run. (See Appendix C Table C-5)

Test 6 . Triplicate analysis of five filtered diluted AP-101 simulant (1:1) solutions in fixed autosampler positions. (See Appendix C Table C-6)

Test 7. Triplicate analysis of five filtered diluted Acidic AP-101 simulant solutions in fixed autosampler positions. (See Appendix C Table C-7)

Test 1 mentioned above used ten 5-mL aliquots of filtered undiluted AN-105 simulant. The samples in Tests 2 through 6 were prepared by pipetting $5-\mathrm{mL}$ of the simulant along with $5-\mathrm{mL}$ of DI water into a polyethylene bottle. An 8-mL aliquot was pipetted into a sample cup with an Ultralene $^{\mathrm{TM}}$ film on one side of the sample cup and a microporous Telfon ${ }^{\mathrm{TM}}$ film on the other side. The samples in Test 7 were prepared by pipetting $5-\mathrm{mL}$ of the listed simulant with 2.5-mL of DI water plus $2.5-\mathrm{mL}$ of $\mathrm{HNO}_{3}$ into a polyethylene bottle. An 8-mL aliquot was pipetted into a sample cup put together as mentioned above. For Tests 2-7, the sample cups were placed into the five autosampler positions and analyzed in triplicate under a helium atmosphere.

Since the Rigaku WD-XRF system is a sequential instrument, $\sim 30$ to 40 min was required for each sample analysis depending on the number of elements scanned. The instrument conditions: peak and background positions, peak and background times, crystals, and detectors can be found in Section 3.5 Table 10. The background subtracted peak intensities, averages, standard deviations, and percent relative standard deviations (\%RSD) are tabulated in Appendix C.

\subsection{Quantitative Application File}

Figure 3 shows the operational flow bar to create a quantitative application file. The directions of how to create a quantitative application file, which start on page 3-6 of the ZSXmini II X-ray 
WSRC-STI-2007-00438

SRNL-RPP-2007-00020

Fluorescence Spectrometer Instruction Manual, are well outlined, and therefore will not be documented here.

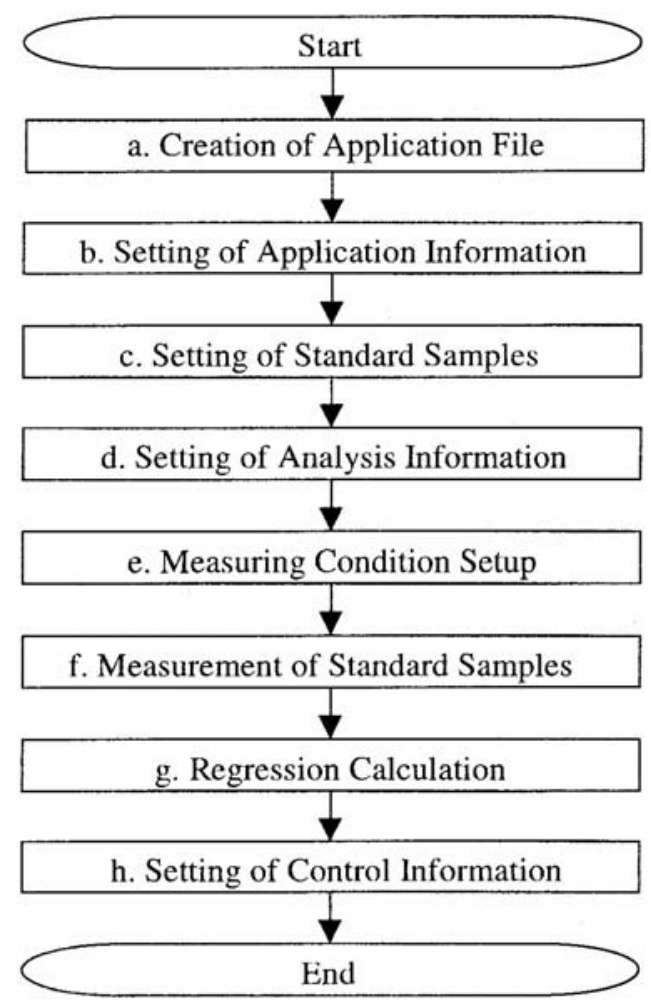

Figure 3. The operational flow bar to create an application file.

The instrument parameters, which where used in the quantification of the simulants representative of the LAW envelopes, are contained in Table 10. The simulants were run using the FP quantification method. There are several restrictions when using the FP approach: (1) The concentration of the standard(s) must equal 99.0 to $101 \mathrm{wt} \%$. Any unmeasured component must be defined as a fixed value, manual input value or a balance component. For example, water $\left(\mathrm{H}_{2} \mathrm{O}\right)$ was used as a balance component when inputting the standard(s). (2) Elements must be distributed uniformly in the sample. (3) Only matrix effects can be corrected. (4) Standards used to prepare the calibration curve should be similar in concentration to the unknown samples. 
WSRC-STI-2007-00438

SRNL-RPP-2007-00020

Table 10. Instrument Conditions.

\begin{tabular}{|c|c|c|c|c|c|c|c|c|c|}
\hline Element & Line & Crystal & Detector & $\begin{array}{l}\text { Peak } \\
\text { (deg) }\end{array}$ & $\begin{array}{l}\text { Time } \\
\text { (sec) }\end{array}$ & $\begin{array}{r}\text { BG1 } \\
\text { (deg) }\end{array}$ & $\begin{array}{l}\text { Time } \\
\text { (sec) }\end{array}$ & $\begin{array}{c}\text { BG2 } \\
\text { (deg) }\end{array}$ & $\begin{array}{l}\text { Time } \\
\text { (sec) }\end{array}$ \\
\hline $\mathrm{Na}$ & $\mathrm{K} \alpha$ & $\mathrm{RX} 35^{1}$ & $\mathrm{PC}^{2}$ & 25.202 & 200 & 22.500 & 100 & 27.500 & 100 \\
\hline Al & $\mathrm{K} \alpha$ & $\mathrm{PET}^{3}$ & $\mathrm{PC}$ & 144.468 & 200 & 140.000 & 100 & $\mathrm{a}$ & $\mathrm{a}$ \\
\hline $\mathbf{P}$ & $\mathrm{K} \alpha$ & PET & $\mathrm{PC}$ & 89.447 & 200 & 91.500 & 100 & $\mathrm{a}$ & $\mathrm{a}$ \\
\hline $\mathrm{S}$ & $\mathrm{K} \alpha$ & PET & PC & 75.687 & 200 & 78.000 & 100 & $\mathrm{a}$ & $\mathrm{a}$ \\
\hline Cl & $\mathrm{K} \alpha$ & PET & $\mathrm{PC}$ & 65.401 & 200 & 67.500 & 100 & $\mathrm{a}$ & $\mathrm{a}$ \\
\hline $\mathbf{K}$ & $\mathrm{K} \alpha$ & PET & $\mathrm{PC}$ & 50.642 & 200 & 48.500 & 100 & $\mathrm{a}$ & $\mathrm{a}$ \\
\hline Ca & $\mathrm{K} \alpha$ & $\mathrm{LIF}{ }^{4}$ & $\mathrm{SC}^{5}$ & 113.004 & 200 & 115.000 & 100 & $\mathrm{a}$ & $\mathrm{a}$ \\
\hline $\mathrm{Cr}$ & $\mathrm{K} \alpha$ & LIF1 & $\mathrm{SC}$ & 69.307 & 200 & 70.200 & 100 & $\mathrm{a}$ & $\mathrm{a}$ \\
\hline $\mathbf{N i}$ & $\mathrm{K} \alpha$ & LIF1 & $\mathrm{SC}$ & 48.613 & 200 & 49.500 & 100 & $\mathrm{a}$ & $\mathrm{a}$ \\
\hline Mo & $\mathrm{K} \alpha$ & LIF1 & $\mathrm{SC}$ & 20.228 & 200 & 19.720 & 100 & 20.920 & 100 \\
\hline
\end{tabular}

${ }^{1} \mathrm{~W} / \mathrm{Si}$ multilayer diffraction crystal, $2 \mathrm{~d}=55 \AA$.

$210 \%$ methane $/ 90 \%$ argon flow proportional counter.

${ }^{3}$ Pentaerythritol diffraction crystal $(020), 2 \mathrm{~d}=8.808 \AA$.

${ }^{4}$ Lithium fluoride (200) crystal, $2 \mathrm{~d}=4.027 \AA$.

${ }^{5}$ Sodium Iodide scintillation detector.

a Only one background point measured.

\subsection{Simulant and Standard Preparations}

A direct liquid analysis method was used to prepare the simulant representative of the LAW Envelopes and the standards. Two preparation methods were evaluated on the simulants: basic and acidic. The simulant samples in both methods were diluted to match to the lower elemental concentration in the standards. In the basic method, $5-\mathrm{mL}$ of the simulant was pipetted into a polyethylene bottle along with $5-\mathrm{mL}$ of DI water. In the acid method, 5-mL of simulant was pipetted into a polyethylene bottle along with $2.5-\mathrm{mL}$ of DI water and $2.5-\mathrm{mL}$ of $70 \% \mathrm{HNO}_{3}$. An aliquot of $8-\mathrm{mL}$ of the above mixtures was pipetted out of the polyethylene bottles for each method into a 31-mm diameter circular sample cell, which was covered on the bottom by a piece of 4- $\mu \mathrm{m}$ Ultralene ${ }^{\mathrm{TM}}$ (polyethylene). The choice of Ultralene ${ }^{\mathrm{TM}}$ over other films was reported by Jurgensen. Also, an aliquot of 8-mL was pipetted directly out of the standard bottles into a circular sample cup. The top of the sample cell was covered with a microporous Teflon ${ }^{\mathrm{TM}}$ film that allows for pressure equalization during the analysis. This microporous film prevents the sample surface from distending outwards as the sample is heated, changing the sample to the x-ray source and detector distances. Film preparation was the same for simulants as for the standards. The sample cells were placed in the aluminum holders on the 12-position sample wheel and were analyzed under helium atmosphere, 99.999\% He, to minimize light element x-ray absorption.

\subsection{Calibration}

X-ray spectrometry is essentially a comparative technique. It is absolutely vital that both calibration reference materials and samples to be analyzed are prepared in an identical and reproducible manner and presented and analyzed by the spectrometer under the same 
WSRC-STI-2007-00438

SRNL-RPP-2007-00020

experimental conditions. Table 8 in Section 3.3 lists the concentrations of the ten elements that makeup the five standards. As mentioned earlier, the standards were manufactured by High Purity Standards in Charleston, South Carolina. The Standard Certificates of Analysis and the MSDS's can be found in Appendix B.

The XRF instrument was calibrated using the fundamental parameters algorithm supplied by Rigaku/MSC. The fundamental parameters approach is the derivation of mathematical expressions quantifying fluorescence emissions in terms of fundamental physical parameter and instrumental parameters. Although this method can be standardless, more accurate determinations can be made by analyzing known matrix-matched standards to adjust the primary and secondary absorption and fluorescence factors, jump ratios, and other coefficients in the fundamental parameter algorithm. Relative intensities are calculated from theoretical principles using the fundamental parameter algorithm based on the Sherman equation. These theoretical intensities are compared with the measured intensities, the projected sample composition is adjusted to match these theoretical intensities, and the process is repeated until convergence. Representative calibration curves based on using all five standards and DI water can be found in Appendix D.

Three different methods were tested using this fundamental parameters approach:

Method 1. Calibrating the instrument using the five High Purity standards and then analyzing the filtered diluted (1:1) acidic simulants.

Method 2. Calibrating the instrument using the five High Purity standards and then analyzing the filtered diluted (1:1) basic simulants.

Method 3. Calibrating the instrument using four High Purity standards one time, and then daily using a High Purity standard as a drift monitor on filtered diluted (1:1) basic simulants.

The instrument conditions, peak and background positions, peak and background times, crystals, and detectors can be found in Section 3.5 Table 10. The simulants and standards were prepared as outlined in Section 3.5. The calibration of the instrument was conducted every day the simulants were run for Methods 1 and 2. The total time to calibrate the instrument for Methods 1 and 2 was $\sim 6$ hours. To check the calibration of the instrument, one of the standards was used as a Quality Control, QC, check standard. The QC standard was changed from run to run. Appendix E Table E-4 contains the results for the QC. 
WSRC-STI-2007-00438

SRNL-RPP-2007-00020

\section{Results and Discussion}

\subsection{Precision}

When comparing the results from the first two tests, the \%RSD values for both tests are similar to Jurgensen indicating adequate installation. Table 11 shows the results of this comparison.

Table 11. Test 1 and Test $2 \%$ RSD.

\begin{tabular}{ccc}
\hline \hline & $\begin{array}{c}\text { Test 1 }^{\text {a }} \\
\text { \% RSD }\end{array}$ & $\begin{array}{c}\text { Test 2 }^{\text {b }} \\
\text { \% RSD }\end{array}$ \\
\hline \hline Na & 5.6 & 3.8 \\
Al & 2.7 & 2.2 \\
$\mathbf{P}$ & 3.0 & 5.0 \\
$\mathbf{C l}$ & 0.4 & 2.6 \\
$\mathbf{K}$ & 3.8 & 3.3 \\
$\mathbf{C r}$ & 0.8 & 2.0 \\
\hline \hline \\
${ }^{\mathrm{a}}$ Triplicate analysis on ten samples. \\
${ }^{\mathrm{b}}$ Triplicate analysis on five samples.
\end{tabular}

In the earlier precision studies, there was sample degradation, particularly for $\mathrm{Al}$ and $\mathrm{K}$. The reason for these intensity drifts is unknown. Likely candidates for intensity drifts are sample heating by the $\mathrm{x}$-ray source and distension of the sample film toward the x-ray tube as it heats or possibly degradation of the solutes and/or complexing agents by the intense x-ray beam. These intensity drifts were observed in Tests 2-6, but not to the extent as in the previous precision study. One reason that these intensity drifts were not as prevalent in Tests 2-6 is that the samples were diluted. Another reason that the intensity drifts were not as pronounced was samples were heated inside the instrument for a shorter time period.

Even with these intensity drifts in Test $2-6$, the \%RSD is $<10 \%$ with the exception of molybdenum which has a very low concentration in the AN-105 and AP-101 simulants. The last precision test compared the difference of using a basic solution, Test 6 , versus an acidified solution, Test 7. AP-101 simulant was used for this comparison. The results show that the $\%$ RSD improved when the simulant was converted from a basic solution to an acidic solution with the exception of molybdenum. The \%RSD for all elements with the exception of molybdenum in the acidic test were $<5 \%$. The molybdenum precision should be significantly better for both tests since molybdenum is a heavy element, but the samples are not infinitely thick for Mo K $\alpha$ X-rays. The lower values in the acidic test indicate that the samples are more stable and not hampered by precipitation issues. Table 12 shows the result of this comparison. 
WSRC-STI-2007-00438

SRNL-RPP-2007-00020

Table 12. Basic and Acidic AP-101 Simulant \%RSD.

\begin{tabular}{ccc}
\hline \hline & $\begin{array}{c}\text { Basic } \\
\text { AP-101 }\end{array}$ & $\begin{array}{c}\text { Acidic } \\
\text { AP-101 }\end{array}$ \\
\hline \hline $\mathbf{N a}$ & 3.7 & 2.8 \\
$\mathbf{A l}$ & 7.7 & 2.0 \\
$\mathbf{P}$ & 2.1 & 1.9 \\
$\mathbf{C l}$ & 1.7 & 1.0 \\
$\mathbf{K}$ & 0.9 & 0.5 \\
$\mathbf{C r}$ & 1.8 & 1.5 \\
$\mathbf{M o}$ & 12.0 & 19.6 \\
$\mathbf{S}$ & 5.0 & 1.1 \\
\hline \hline
\end{tabular}

\subsection{XRF Results}

Method 3 used a drift monitor after the initial calibration. A drift monitor is a sample or standard that corrects long term drifts of the X-ray intensities. The drift monitor sample must be stable over long periods of time and contain all the analytes at high concentrations. Normally a glass or metal standard with high analyte concentrations is used as the drift monitor. By using a drift monitor, one would calibrate the instrument initially, which takes $\sim 6$ hours, and then daily run the drift monitor before any analysis. The drift monitor method would save $\sim 5$ hours of calibration time. The instrument was calibrated for this test using Standards B through E. Standard A was used as the QC standard, since this standard was from a different lot of starting material compared to the other standards, and Standard D was used as the drift monitor.

The results of the three methods can be found in Appendix E. Method 1 was run eleven times while Methods 2 and 3 were run only five times. Table 13 compares the average values for the three methods. The results for Methods 2 and 3 are higher than the Method 1. One reason for the higher results in Method 2 is that the simulants and standards matrices were different. The simulants were basic while the standards were prepared in $4 \% \mathrm{HNO}_{3}$. Another reason for the differences in concentrations between these two methods could have come from simulant being degraded by the intense x-ray beam. The drift monitor, Standard D, used in Method 3 to correct the drift of the x-ray intensities on a daily basis under-corrected the intensities, causing the concentration higher than Method 1. This imperfect correction is expected on using a lower concentration liquid standard as the drift monitor. Better results could be obtained using a standard with concentrations between $1-5 \mathrm{wt} \%$ for corrections to achieve intensities near $1,000,000$ counts.

High sodium concentration was observed in one DI water blank for Methods 1 and 2. The potential source of the sodium contamination is the high salt simulants. 
Table 13. WD-XRF Average Results for the Three Data Sets.

\begin{tabular}{|c|c|c|c|c|c|c|}
\hline Element & $\begin{array}{c}\text { Acidified }^{1} \\
\text { AN-105 } \\
\text { XRF average } \\
\mu \mathrm{g} / \mathrm{mL}\end{array}$ & $\begin{array}{c}\text { Basic }^{2} \\
\text { AN-105 } \\
\text { XRF average } \\
\mu \mathrm{g} / \mathrm{mL}\end{array}$ & $\begin{array}{c}\text { Drift Corrected }^{2} \\
\text { AN-105 } \\
\text { XRF average } \\
\mu \mathrm{g} / \mathrm{mL}\end{array}$ & $\begin{array}{c}\text { Acidified }^{1} \\
\text { AP-101 } \\
\text { XRF average } \\
\mu \mathrm{g} / \mathrm{mL}\end{array}$ & $\begin{array}{c}\text { Basic }^{2} \\
\text { AP-101 } \\
\text { XRF average } \\
\mu \mathrm{g} / \mathrm{mL}\end{array}$ & $\begin{array}{c}\text { Drift Corrected }^{2} \\
\text { AP-101 } \\
\text { XRF average } \\
\mu \mathrm{g} / \mathrm{mL}\end{array}$ \\
\hline בAl & 1011400 & 1212400 & 12000 & 70 & 7530 & 7470 \\
\hline Ca & $<10$ & $<10$ & $<10$ & $<10$ & $<10$ & $<10$ \\
\hline $\mathrm{Cr}$ & 684 & 745 & 690 & 155 & 172 & 157 \\
\hline Mo & 41 & 43 & 40 & 14 & 15 & 13 \\
\hline $\mathrm{Ni}$ & $<2$ & $<2$ & $<2$ & $<2$ & $<2$ & $<2$ \\
\hline $\mathbf{K}$ & 3880 & 4240 & 3960 & 28100 & 30600 & 28600 \\
\hline $\mathrm{Na}$ & 129000 & 142000 & 137000 & 123000 & 134000 & 130000 \\
\hline $\mathrm{S}$ (also measured as $\mathrm{SO}_{4}$ ) & 389 & 482 & 452 & 3690 & 4040 & 3820 \\
\hline $\mathrm{P}$ (also measured as $\mathrm{PO}_{4}$ ) & 356 & 389 & 307 & 1290 & 1390 & 1340 \\
\hline Cl & 4970 & 5510 & 5360 & 1570 & 1730 & 1710 \\
\hline Element & $\begin{array}{c}\text { Acidified }^{1} \\
\text { AN-107 } \\
\text { XRF average } \\
\mu \mathrm{g} / \mathrm{mL} \\
\end{array}$ & $\begin{array}{c}\text { Basic }^{2} \\
\text { AN-107 } \\
\text { XRF average } \\
\mu \mathrm{g} / \mathrm{mL} \\
\end{array}$ & $\begin{array}{c}\text { Drift Corrected }^{2} \\
\text { AN-107 } \\
\text { XRF average } \\
\mu \mathrm{g} / \mathrm{mL} \\
\end{array}$ & $\begin{array}{c}\text { Acidified }^{1} \\
\text { AZ-101 } \\
\text { XRF average } \\
\mu \mathrm{g} / \mathrm{mL} \\
\end{array}$ & $\begin{array}{c}\text { Basic }^{2} \\
\text { AZ-101 } \\
\text { XRF average } \\
\mu \mathrm{g} / \mathrm{mL} \\
\end{array}$ & $\begin{array}{c}\text { Drift Corrected }^{2} \\
\text { AZ-101 } \\
\text { XRF average } \\
\mu \mathrm{g} / \mathrm{mL} \\
\end{array}$ \\
\hline Al & 281 & 346 & 414 & $<><0$ & $<><0$ & $<80$ \\
\hline Ca & 147 & 164 & 155 & $<10$ & $<10$ & $<10$ \\
\hline $\mathrm{Cr}$ & $<5$ & $<5$ & $<5$ & 150 & 169 & 157 \\
\hline Mo & 21 & 21 & 19 & 25 & 27 & 24 \\
\hline $\mathrm{Ni}$ & 305 & 335 & 307 & $<2$ & $<2$ & $<2$ \\
\hline $\mathbf{K}$ & 1180 & 1320 & 1200 & 902 & 1040 & 911 \\
\hline $\mathrm{Na}$ & 145000 & 160000 & 152000 & 9780 & 12300 & 13200 \\
\hline $\mathrm{S}$ (also measured as $\mathrm{SO}_{4}$ ) & 4970 & 5510 & 4750 & 829 & 972 & 900 \\
\hline $\mathrm{P}$ (also measured as $\mathrm{PO}_{4}$ ) & 935 & 1050 & 955 & $<30$ & $<30$ & $<30$ \\
\hline Cl & 1350 & 1530 & 1470 & 281 & 312 & 314 \\
\hline
\end{tabular}

${ }^{1}$ An average of 11 runs.

${ }^{2}$ An average of 5 runs.

The average results for Method 1 were compared against the average results for the ICP-AES and IC results for the simulants. Table 14 shows this comparison. The average results for the ICP-AES were based on ten runs using ten different calibrations. The average results for the IC were based on 5 runs using five different calibrations. Because of matrix effects, sulfate number was not reported on the IC. The results for all the runs for both the ICP-AES and IC are located in Appendix F. A thorough statistical analysis of this data can be found in SRNL-SCS-2007-00042 ${ }^{6}$. "Although measurements obtained by XRF (both acidic, Method 1, and basic, Method 2, preparations) are different from those obtained by ICP-AES and IC, the XRF acidic preparation measurements are sufficiently similar to the measurements made by ICP-AES or IC that either method could be used. The variance analysis suggests that ICP-AES and IC tend to be roughly equal to XRF in terms of uncertainty. Furthermore, the various analyses on the mean measurements indicate that ICP-AES and IC tend to yield smaller measurements than XRF, especially when the XRF samples are prepared using the basic solution. In particular, the XRF method does return smaller mean measurements than ICP-AES or IC for some of the elements of interest when the XRF samples are prepared using the acid solutions. When all ten of the measured elements are considered together, it appears that the overall analysis obtained using the acidic preparation for XRF is statistically equivalent to that obtained by ICP-AES and IC ."

\footnotetext{
${ }^{6}$ M. D. Joner, “A Statistical Comparison of XRF, ICP-AES, and IC Measurements”, SRNL-SCS-2007-00042, Washington Savannah River Company, (to be issued).
} 
WSRC-STI-2007-00438

SRNL-RPP-2007-00020

Table 14. Average Concentrations for the WD-XRF, Method 1, ICP-AES, and IC.

\begin{tabular}{|c|c|c|c|c|c|c|}
\hline Element & $\begin{array}{c}\text { AN-105 } \\
\text { XRF average } \\
\mu \mathrm{g} / \mathrm{mL}\end{array}$ & $\begin{array}{c}\text { AN-105 } \\
\text { ICP Average } \\
\mu \mathrm{g} / \mathrm{mL}\end{array}$ & $\begin{array}{c}\text { AN-105 } \\
\text { IC Average } \\
\mu \mathrm{g} / \mathrm{mL}\end{array}$ & $\begin{array}{c}\text { AP-101 } \\
\text { XRF average } \\
\mu \mathrm{g} / \mathrm{mL}\end{array}$ & $\begin{array}{c}\text { AP-101 } \\
\text { ICP Average } \\
\mu \mathrm{g} / \mathrm{mL}\end{array}$ & $\begin{array}{c}\text { AP-101 } \\
\text { IC Average } \\
\mu \mathrm{g} / \mathrm{mL}\end{array}$ \\
\hline$\overline{\mathrm{Al}}$ & 1011400 & ב 10600 & 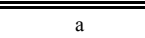 & ב 7060 & 68850 & 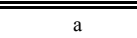 \\
\hline Ca & $<10$ & $<3.81$ & a & $<10$ & $<3.81$ & a \\
\hline $\mathrm{Cr}$ & 684 & 640 & a & 155 & 152 & a \\
\hline Mo & 41 & 40 & a & 14 & 14 & a \\
\hline $\mathrm{Ni}$ & $<2$ & 1 & a & $<2$ & $<0.35$ & a \\
\hline $\mathbf{K}$ & 3880 & 3770 & a & 28100 & 28200 & a \\
\hline $\mathrm{Na}$ & 129000 & 122000 & $\mathrm{a}$ & 123000 & 120000 & $\mathrm{a}$ \\
\hline $\mathrm{S}$ (also measured as $\mathrm{SO}_{4}$ ) & 389 & 393 & 140 & 3690 & 3810 & 3450 \\
\hline $\mathrm{P}$ (also measured as $\mathrm{PO}_{4}$ ) & 356 & 289 & $\mathrm{~b}$ & 1290 & 1210 & $\mathrm{~b}$ \\
\hline Cl & 4970 & $\mathrm{a}$ & 4600 & 1570 & $\mathrm{a}$ & 1490 \\
\hline Element & $\begin{array}{c}\text { AN-107 } \\
\text { XRF average } \\
\mu \mathrm{g} / \mathrm{mL} \\
\end{array}$ & $\begin{array}{c}\text { AN-107 } \\
\text { ICP Average } \\
\mu \mathrm{g} / \mathrm{mL} \\
\end{array}$ & $\begin{array}{c}\text { AN-107 } \\
\text { IC Average } \\
\mu \mathrm{g} / \mathrm{mL}\end{array}$ & $\begin{array}{c}\text { AZ-101 } \\
\text { XRF average } \\
\mu \mathrm{g} / \mathrm{mL}\end{array}$ & $\begin{array}{c}\text { AZ-101 } \\
\text { ICP Average } \\
\mu \mathrm{g} / \mathrm{mL}\end{array}$ & $\begin{array}{c}\text { AZ-101 } \\
\text { IC Average } \\
\mu \mathrm{g} / \mathrm{mL}\end{array}$ \\
\hline$\overline{\mathrm{Al}}$ & 281 & 236 & $\mathrm{a}$ & $<80$ & $<2.56$ & $\mathrm{a}$ \\
\hline Ca & 147 & 145 & a & $<10$ & $<3.81$ & a \\
\hline $\mathrm{Cr}$ & $<5$ & 0.64 & a & 148 & 142 & a \\
\hline Mo & 21 & 22 & a & 26 & 26 & a \\
\hline $\mathbf{N i}$ & 305 & 301 & a & $<2$ & $<0.558$ & a \\
\hline $\mathbf{K}$ & 1180 & 1200 & a & 932 & 781 & a \\
\hline $\mathrm{Na}$ & 145000 & 141000 & a & 9780 & 11500 & a \\
\hline $\mathrm{S}$ (also measured as $\mathrm{SO}_{4}$ ) & 4970 & 5200 & 4710 & 845 & 800 & 748 \\
\hline $\mathrm{P}$ (also measured as $\mathrm{PO}_{4}$ ) & 935 & 894 & $\mathrm{~b}$ & $<30$ & $<60$ & $\mathrm{~b}$ \\
\hline Cl & 1350 & $\mathrm{a}$ & 1500 & 306 & $\mathrm{a}$ & 259 \\
\hline
\end{tabular}

a) These elements could not measured by the given method.

b) Because of martix effects, $\mathrm{PO}_{4}{ }^{2-}$ was not reported.

Tables 15 through 18 compare the average results and one sigma values between Method 1 to the ICP-AES and IC results for each element in the four simulants. The less than values reported in Tables 13 through 18 for Al, Ca, Ni, Cr, and PO4 are very good estimates of the detection limits, which were determined by making several dilutions from ICP-AES and IC standards. Each set of dilutions for a particular element was scanned included a DI water blank, and the scans were overlaid in the software. The XRF less than values were estimated to be where analyte peak was determined to be above the DI water blank spectra. A typical method at SRNL to determine the detection limits is the IUPAC calculation, as detailed by Jurgensen. 
WSRC-STI-2007-00438

SRNL-RPP-2007-00020

Table 15. AN-105 Average Concentrations and Standard Deviation for the WD-XRF Method 1, ICP-AES, and IC.

\begin{tabular}{|c|c|c|c|c|c|c|}
\hline Element & $\begin{array}{c}\mathrm{AN}-105 \\
\text { XRF average } \\
\mu \mathrm{g} / \mathrm{mL}\end{array}$ & $1 \sigma$ & $\begin{array}{c}\text { AN-105 } \\
\text { ICP Average } \\
\mu \mathrm{g} / \mathrm{mL}\end{array}$ & $1 \sigma$ & $\begin{array}{c}\text { AN-105 } \\
\text { IC Average } \\
\mu \mathrm{g} / \mathrm{mL}\end{array}$ & $1 \sigma$ \\
\hline Al & 11400 & 339 & 10600 & 516 & $\mathrm{a}$ & - \\
\hline Ca & $<10$ & - & $<3.81$ & - & a & - \\
\hline Cr & 684 & 11 & 640 & 35 & a & - \\
\hline Mo & 41 & 2 & 40 & 2.3 & $\mathrm{a}$ & - \\
\hline $\mathbf{N i}$ & $<2$ & - & $<0.35$ & - & a & - \\
\hline $\mathbf{K}$ & 3880 & 74 & 3700 & 183 & a & - \\
\hline $\mathrm{Na}$ & 129000 & 7650 & 122000 & 6350 & a & - \\
\hline $\mathrm{S}$ (also measured as $\mathrm{SO}_{4}$ ) & 389 & 65 & 398 & 23 & 140 & 13 \\
\hline $\mathrm{P}$ (also measured as $\mathrm{PO}_{4}$ ) & 356 & 18 & 289 & 15 & $\mathrm{~b}$ & - \\
\hline Cl & 4970 & 115 & $\mathrm{a}$ & - & 4600 & 82 \\
\hline
\end{tabular}

a) These elements could not be measured by the given method.

b) Because of martix effects, $\mathrm{PO}_{4}{ }^{2-}$ was not reported.

Table 16. AP-101 Average Concentrations and Standard Deviation for WD-XRF Method 1, ICP-AES, and IC.

\begin{tabular}{|c|c|c|c|c|c|c|}
\hline \multirow[b]{2}{*}{ Element } & \multicolumn{2}{|l|}{ AP-101 } & \multirow{2}{*}{$\begin{array}{c}\text { AP-101 } \\
\text { ICP Average } \\
\mu \mathrm{g} / \mathrm{mL} \\
\end{array}$} & \multicolumn{3}{|c|}{ AP-101 } \\
\hline & $\begin{array}{c}\text { XRF average } \\
\mu \mathrm{g} / \mathrm{mL}\end{array}$ & $1 \sigma$ & & $1 \sigma$ & $\begin{array}{c}\text { IC Average } \\
\mu \mathrm{g} / \mathrm{mL}\end{array}$ & $1 \sigma$ \\
\hline Al & 7060 & 178 & 6850 & 99 & $\mathrm{a}$ & - \\
\hline Ca & $<10$ & - & $<3.81$ & - & a & - \\
\hline $\mathrm{Cr}$ & 155 & 4 & 152 & 4 & a & - \\
\hline Mo & 14 & 2 & 14 & 1 & a & - \\
\hline $\mathrm{Ni}$ & $<2$ & - & $<0.35$ & - & $\mathrm{a}$ & - \\
\hline $\mathbf{K}$ & 28100 & 273 & 28200 & 673 & a & - \\
\hline $\mathrm{Na}$ & 123000 & 4460 & 120000 & 3300 & a & - \\
\hline $\mathrm{S}$ (also measured as $\mathrm{SO}_{4}$ ) & 3690 & 82 & 3810 & 89 & 3450 & 34 \\
\hline $\mathrm{P}$ (also measured as $\mathrm{PO}_{4}$ ) & 1290 & 39 & 1210 & 40 & $\mathrm{~b}$ & - \\
\hline Cl & 1570 & 23 & $\mathrm{a}$ & - & 1490 & 21 \\
\hline
\end{tabular}

a) These elements could not be measured by the given method.

b) Because of martix effects, $\mathrm{PO}_{4}{ }^{2-}$ was not reported. 
WSRC-STI-2007-00438

SRNL-RPP-2007-00020

Table 17. AN-107 Average Concentrations and Standard Deviation for the WD-XRF Method 1, ICP-AES, and IC.

\begin{tabular}{|c|c|c|c|c|c|c|}
\hline Element & $\begin{array}{c}\text { AN-107 } \\
\text { XRF average } \\
\mu \mathrm{g} / \mathrm{mL} \\
\end{array}$ & $1 \sigma$ & $\begin{array}{c}\text { AN-107 } \\
\text { ICP Average } \\
\mu \mathrm{g} / \mathrm{mL}\end{array}$ & $1 \sigma$ & $\begin{array}{c}\text { AN-107 } \\
\text { IC Average } \\
\mu \mathrm{g} / \mathrm{mL}\end{array}$ & $1 \sigma$ \\
\hline Al & 281 & 67 & 236 & 3 & a & - \\
\hline Ca & 147 & 8 & 145 & 3 & a & - \\
\hline $\mathrm{Cr}$ & $<5$ & - & 1 & 0.2 & a & - \\
\hline Mo & 21 & 2 & 22 & 0.7 & a & - \\
\hline $\mathbf{N i}$ & 305 & 4 & 301 & 8 & a & - \\
\hline $\mathbf{K}$ & 1180 & 47 & 1200 & 67 & a & - \\
\hline $\mathrm{Na}$ & 145000 & 5820 & 141000 & 4820 & a & - \\
\hline $\mathrm{S}$ (also measured as $\mathrm{SO}_{4}$ ) & 4970 & 73 & 5200 & 131 & 4710 & 58 \\
\hline $\mathrm{P}$ (also measured as $\mathrm{PO}_{4}$ ) & 935 & 40 & 894 & 17 & $\mathrm{~b}$ & - \\
\hline Cl & 1350 & 27 & $\mathrm{a}$ & - & 1500 & 156 \\
\hline
\end{tabular}

a) These elements could not be measured by the given method.

b) Because of martix effects, $\mathrm{PO}_{4}{ }^{2-}$ was not reported.

Table 18. AZ-101 Average Concentrations and Standard Deviation for the WD-XRF Method 1, ICP-AES, and IC.

\begin{tabular}{|c|c|c|c|c|c|c|}
\hline \multirow[b]{2}{*}{ Element } & \multicolumn{2}{|l|}{ AZ-101 } & \multicolumn{2}{|l|}{ AZ-101 } & \multicolumn{2}{|l|}{ AZ-101 } \\
\hline & $\begin{array}{c}\text { XRF average } \\
\mu \mathrm{g} / \mathrm{mL}\end{array}$ & $1 \sigma$ & $\begin{array}{c}\text { ICP Average } \\
\mu \mathrm{g} / \mathrm{mL}\end{array}$ & $1 \sigma$ & $\begin{array}{c}\text { IC Average } \\
\mu \mathrm{g} / \mathrm{mL}\end{array}$ & $1 \sigma$ \\
\hline $\mathbf{A l}$ & $<80$ & - & $<2.56$ & - & $\bar{a}$ & - \\
\hline Ca & $<10$ & - & $<3.81$ & - & a & - \\
\hline $\mathrm{Cr}$ & 150 & 6 & 142 & 3 & a & - \\
\hline Mo & 25 & 1 & 26 & 1 & a & - \\
\hline $\mathbf{N i}$ & $<2$ & - & $<0.558$ & - & a & - \\
\hline $\mathbf{K}$ & 902 & 56 & 781 & 25 & a & - \\
\hline $\mathrm{Na}$ & 9780 & 761 & 11500 & 247 & $\mathrm{a}$ & - \\
\hline $\mathrm{S}$ (also measured as $\mathrm{SO}_{4}$ ) & 829 & 46 & 801 & 21 & 748 & 50 \\
\hline $\mathrm{P}$ (also measured as $\mathrm{PO}_{4}$ ) & $<30$ & - & $<60$ & - & $\mathrm{b}$ & - \\
\hline Cl & 281 & 16 & $\mathrm{a}$ & - & 259 & 14 \\
\hline
\end{tabular}

a) These elements could not be measured by the given method.

b) Because of martix effects, $\mathrm{PO}_{4}{ }^{2-}$ was not reported.

Silicon concentration in the simulants was not determined by XRF because High Purity had problems with silicon precipitating out of solution. The XRF detection limit for silicon was estimated to be $<30-\mu \mathrm{g} / \mathrm{mL}$. A High Purity ICP-AES $1000-\mu \mathrm{g} / \mathrm{mL}$ Si in $\mathrm{H}_{2} \mathrm{O}$ standard was used to estimate the detection limit. The detection limit for silicon was determined in the same way as mentioned above for $\mathrm{Al}, \mathrm{Ca}, \mathrm{Cr}, \mathrm{Ni}$, and $\mathrm{PO}_{4}$. 


\subsection{X-ray Fluorescence (XRF) Counting Statistics}

The relative fractional counting uncertainty was determined for the 11 acidified runs and the 5 basic runs using all five High Purity standards in the calibration of the instrument. The relative fractional counting uncertainty was calculated using the following equation:

$$
\varepsilon_{N}=\frac{\sqrt{N}}{N} \times 100
$$

where

$\varepsilon_{\mathrm{N}}$ is the relative standard deviation of the individual measurement $\mathrm{N}$ is the number of counts.

The results for the relative fractional counting uncertainty for these two tests are in Appendix G. By comparing the average relative standard deviation of the simulants to the average relative fractional counting uncertainty, the average relative fractional counting uncertainties are much smaller than the average relative standard deviations for all the elements in the simulants. Table 19 and 20 show the results of the comparison for the 11 acidified runs and five basic runs.

Table 19. Comparing the Overall Precision to the Counting Uncertainty for the Acidic Filtered Diluted Simulants.

\begin{tabular}{|c|c|c|c|c|c|c|c|c|}
\hline Element & $\begin{array}{c}\text { AN-105 } \\
\% \text { RSD }\end{array}$ & $\begin{array}{c}\text { AN-105 } \\
\text { Counting } \\
\text { Uncertainty (\%) }\end{array}$ & $\begin{array}{c}\text { AP-101 } \\
\text { \%RSD } \\
\end{array}$ & $\begin{array}{c}\text { AP-101 } \\
\text { Counting } \\
\text { Uncertainty (\%) }\end{array}$ & $\begin{array}{c}\text { AN-107 } \\
\text { \%RSD } \\
\end{array}$ & $\begin{array}{c}\text { AN-107 } \\
\text { Counting } \\
\text { Uncertainty (\%) }\end{array}$ & $\begin{array}{c}\text { AZ-101 } \\
\text { \%RSD }\end{array}$ & $\begin{array}{c}\text { AZ-101 } \\
\text { Counting } \\
\text { Uncertainty (\%) } \\
\end{array}$ \\
\hline$\overline{\mathrm{Al}}$ & 3 & 0.6 & 3 & $\begin{array}{l}0.7 \\
\end{array}$ & 24 & 3.0 & - & - \\
\hline $\mathbf{C a}$ & - & - & - & - & 6 & 2.4 & - & - \\
\hline $\mathrm{Cr}$ & 2 & 0.7 & 2 & 1.3 & - & - & 4 & 1.2 \\
\hline Mo & 5 & 0.2 & 12 & 0.2 & 9 & 0.2 & 4 & 0.2 \\
\hline $\mathbf{N i}$ & - & - & - & - & 1 & 0.5 & - & - \\
\hline $\mathbf{K}$ & 2 & 0.4 & 1 & 0.2 & 4 & 0.5 & 6 & 0.6 \\
\hline $\mathrm{Na}$ & 6 & 0.9 & 4 & 0.9 & 4 & 0.9 & 8 & 2.2 \\
\hline $\mathrm{S}$ (also measured as $\mathrm{SO}_{4}$ ) & 17 & 1.9 & 2 & 0.8 & 1 & 0.7 & 6 & 1.4 \\
\hline $\mathrm{P}$ (also measured as $\mathrm{PO}_{4}$ ) & 5 & 3.4 & 3 & 2.0 & 4 & 2.3 & - & - \\
\hline Cl & 2 & 0.3 & 1 & 0.5 & 2 & 0.6 & 6 & 1.0 \\
\hline
\end{tabular}


WSRC-STI-2007-00438

SRNL-RPP-2007-00020

Table 20. Comparing the Overall Precision to the Counting Uncertainty for the Basic Filtered Diluted Simulants.

\begin{tabular}{|c|c|c|c|c|c|c|c|c|}
\hline Element & $\begin{array}{c}\text { AN-105 } \\
\text { \%RSD }\end{array}$ & $\begin{array}{c}\text { AN-105 } \\
\text { Counting } \\
\text { Uncertainty (\%) }\end{array}$ & $\begin{array}{c}\text { AP-101 } \\
\text { \%RSD }\end{array}$ & $\begin{array}{c}\text { AP-101 } \\
\text { Counting } \\
\text { Uncertainty (\%) }\end{array}$ & $\begin{array}{c}\text { AN-107 } \\
\text { \%RSD }\end{array}$ & $\begin{array}{c}\text { AN-107 } \\
\text { Counting } \\
\text { Uncertainty (\%) }\end{array}$ & $\begin{array}{c}\text { AZ-101 } \\
\text { \%RSD }\end{array}$ & $\begin{array}{c}\text { AZ-101 } \\
\text { Counting } \\
\text { Uncertainty (\%) } \\
\end{array}$ \\
\hline 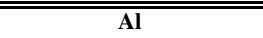 & 6 & 0.6 & 2 & $\begin{array}{ll}0.7 \\
\end{array}$ & 30 & 2.9 & - & - \\
\hline Ca & - & - & - & - & 7 & 2.3 & - & - \\
\hline $\mathrm{Cr}$ & 2 & 0.7 & 4 & 1.2 & - & - & 3 & 1.1 \\
\hline Mo & 4 & 0.2 & 15 & 0.2 & 11 & 0.2 & 7 & 0.2 \\
\hline $\mathrm{Ni}$ & - & - & - & - & 1 & 0.4 & - & - \\
\hline $\mathbf{K}$ & 2 & 0.4 & 1 & 0.2 & 2 & 0.5 & 5 & 0.5 \\
\hline $\mathrm{Na}$ & 3 & 0.9 & 4 & 0.9 & 4 & 0.8 & 23 & 2.1 \\
\hline $\mathrm{S}$ (also measured as $\mathrm{SO}_{4}$ ) & 22 & 1.8 & 3 & 0.7 & 2 & 0.6 & 11 & 1.3 \\
\hline $\mathrm{P}$ (also measured as $\mathrm{PO}_{4}$ ) & 6 & 3.3 & 4 & 1.9 & 3 & 2.2 & - & - \\
\hline Cl & 2 & 0.3 & 2 & 0.5 & 2 & 0.5 & 2 & 1.0 \\
\hline
\end{tabular}

The results indicate that the major source of error is not the instrumental measurement uncertainty, but rather is associated with other preparation and analytical factors, such as preparing the sample cups, distension of the sample film towards the x-ray tube as the sample film heats, or possible degradation of the solutions by the x-ray beam. An additional note regarding sample cups preparation. The $4-\mu \mathrm{m}$ Ultralene $^{\mathrm{TM}}$ film needs to be as flat as possible to avoid any ripples that will distend the film closer to the $\mathrm{x}$-ray source affecting the final results of the measurement.

\section{Quality Assurance}

The Quality Assurance measures identified in the Task Technical and Quality Assurance Plan ${ }^{2}$ were followed in the performance of these activities. The WSRC program applied the appropriate quality assurance requirements from 10 CFR 830 Subpart A, NQA-1-1989 (Part I, Basic and Supplementary Requirements), and NQA-2a-1990, Part 2.7, as indicated by the QA Plan Checklist in Section VIII of the Task Technical and Quality Assurance Plan. A surveillance of the activities was performed by SRNL QA to verify conformance to the QA Plan Checklist. All items that were checked "Yes" in this list were followed with the exception of procedures related to stop work, non-conformance, and the corrective action system. These were not necessary since no issues were identified. SRNL was also requested to perform work in accordance with the requirements established in Quality Assurance Project Plan for Testing Programs Generating Environmental Regulatory Data (PL-24590-QA00001 ${ }^{7}$ ) since the activity supports regulatory and environmental testing for the RPP-WTP.

\subsection{Significant Figures}

The number of significant figures used in this document was based on the following criteria:

- XRF raw data in kcps was input as listed in the instrument printout.

- The number of significant figures for the data set averages, \%RSDs, etc. was based on an estimate of what was appropriate for that particular method at that concentration level.

\footnotetext{
${ }^{7}$ D. Blumenkranz, "Quality Assurance Project for Testing Programs Generating Environmental Regulatory Data", PL-24590-QA00001, Revision 0, June 2001.
} 
WSRC-STI-2007-00438

SRNL-RPP-2007-00020

\section{Conclusions/ Recommendations}

In the precision studies where the basic simulant was run, there was some sample degradation. The reason for these intensity drifts is unknown, but could have been from sample heating by the $\mathrm{x}$-ray source and distension of the sample film toward the x-ray tube as it heats or possibly degradation of the solutes and/or complexing agents by the intense x-ray beam. The precision improved slightly when the basic simulant was diluted 1:1 with DI water, but the problem did not disappear. The results for the precision study where the basic stimulant, AP-101, was converted to an acidic solution were not hampered by the intensity drifts resolving the long term stability that was indicated in Phase 1a.

Three XRF fundamental parameter methods were studied. The results of each XRF method were compared against the results from the ICP-AES and IC methods. The results from the Method 2 and Method 3 were different than the results obtained from the ICP-AES and IC methods. The variance analysis suggests that ICP-AES and IC tend to be roughly equal to Method 1 in terms of uncertainty ${ }^{5}$. The results for Method 1 are statistically comparable to the results of ICP-AES and IC.

SRNL developed an XRF method for WTP LAW vitrification processing support after procuring valid calibration and verification standards that represent LAW compositional ranges. SRNL recommends that when using the XRF fundamental parameters method that the matrix matched standards closely match the waste composition. If the matrix matched standards for the major elements, $\mathrm{Al}$ and $\mathrm{Na}$, are $20 \%$ away from the actual composition, the accuracy and precision of the results will suffer.

Information provided in the Riguka's User manual is sufficient for WTP implementation of this XRF method. The user manual is easy to follow with step by step instructions and pictures of the various steps. 
WSRC-STI-2007-00438

SRNL-RPP-2007-00020

\title{
7. Appendices
}

\subsection{Appendix A: Simulants Hold Point Approval}

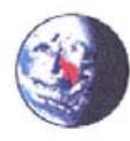

\author{
"Arakali, Aruna" \\ <avarakal@bechtel.com> \\ 06/21/2007 02:08 PM
}

\author{
To frank.pennebaker@srnl.doe.gov \\ cc david.missimer@srnl.doe.gov, \\ arthur,jurgensen@srnl.doe.gov, "Lane, Thomas A" \\ bcc \\ <talane@bechtel.com>. "Lau, Barbara"
}

Subject WTP Hold Point Approval

Frank,

Reviewed the compositional information on selection of LAW simulants. The listed simulants are approved for using as test samples. Proceed with completion of XRF Phase $1 \mathrm{~b}$ task.

Thanks

Aruna V. Arakali

WTP Lab Team

River Protection Project-Waste Treatment Plant

2435 Stevens Center Place MS12-B,

Richland, WA 99354

From: frank.pennebaker@srnl.doe.gov [mailto:frank.pennebaker@srnl.doe.gov]

Sent: Thursday, June 21, 2007 10:31 AM

To: Arakali, Aruna

Cc: david.missimer@srnl.doe.gov; arthur.jurgensen@srnl.doe.gov

Subject: WTP Hold Point

Aruna,

SRNL requests WTP approval for the use of simulants as defined in SRNL-RPP-2004-000091Rev3 Table 6. The task plan designates a hold point for Simulant Sample Selection. SRNL requests use of the following simulants.

- Envelope A - Simulant AN-105 was made by the Full Eibling recipe and diluted to 5M Sodium.

- Envelope A - Simulant AP-101 full recipe

- Envelope C - Simulant AN-107 was produced by a stronium/TRU precipitation after caustic adjustment.

- Envelope B/D simulant with some unknown elemental concentrations was prepared by Optima for Gas Release/ Holdup Tesing. The slurry was centrifuged to separate the solids from the supernate, and then filtered. Some of the values measured below detection limit will be measured by XRF to evaluate performance.

I have included supplemental documents, which give the elemental concentration of each of these simulants, as measured by SRNL. I have also included documentation for the Envelope B/D slurry, prior to filtration. We must complete selection of simulants by June 21 to maintain schedule. If you have any questions, please let me know. Thanks.

Frank Pennebaker

Mgr, Materials Characterization and Nuclear Measurements Group

Savannah River National Laboratory

(803)725-6749 
WSRC-STI-2007-00438

SRNL-RPP-2007-00020

7.2 Appendix B: Standard Certificates of Analysis and Material Safety Data Sheets 
WSRC-STI-2007-00438

SRNL-RPP-2007-00020

P.O. Box 41727

Charleston, SC 29423

TEL: (843) 767-7900

FAX: (843) 767-7906

\title{
HIGH-PURITY
} STANDARDS

\section{Certificate of Analysis}

\author{
SM-744-042 \\ (Standard A)
}

Lot \# 0711714

$\begin{array}{cccc}\text { Source } & \begin{array}{c}\text { Source } \\ \text { Purity }\end{array} & \text { Matrix } & \begin{array}{c}\text { Standard } \\ \text { Concentration }\end{array} \\ \begin{array}{c}\text { High Purity Metals, } \\ \text { Salts or Oxides }\end{array} & 99.995+\% & \mathrm{HNO}_{3}, 4 \% & \begin{array}{c}\mu \mathrm{g} / \mathrm{mL} \pm 0.5 \% \\ \text { See element list on reverse }\end{array}\end{array}$

This spectrometric standard solution has been prepared from high-purity reference materials. Sub-boiling distilled high-purity acid has been used to place the materials in solution and to stabilize the standard. The matrix is as noted above in 18 megaohm deionized water. The reference materials have been assayed by inductively coupled plasma optical emission spectrometry (ICP-OES) and ion chromatography (IC).

The standard has been prepared gravimetrically by weighing the reference material to 5 significant figures. Volumetric glassware has been calibrated gravimetrically to 5 significant figures. The standard concentration has been verified by ICP-OES and IC against an independent source which is directly traceable to National Institute of Standards and Technology, Standard Reference Material No. 3100 series.

This standard is valid for three months from the shipping date provided the solution is kept tightly capped and stored under normal laboratory conditions. Expiration date may be extended as stability is determined. This standard was prepared from different master solutions than the other standards in this series.

Exp Date: AUG $0 \quad 52007$

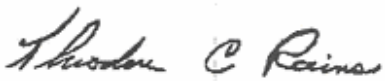

Theodore C. Rains, Ph.D.

MSDS ATTACHED

President

Figure B - 1. Standard A Certificate of Analysis. 
WSRC-STI-2007-00438

SRNL-RPP-2007-00020

SM-744-042

(Standard A)

Element List $(\mu \mathrm{g} / \mathrm{mL})$

$\begin{array}{lr}\text { Aluminum } & 8850 \\ \text { Calcium } & 500 \\ \text { Chromium } & 250 \\ \text { Molybdenum from }\left(\mathrm{NH}_{4}\right)_{2} \mathrm{MoO}_{4} & 5 \\ \text { Nickel } & 375 \\ \text { Potassium } & 225 \\ \text { Sodium } & 36,500 \\ \text { Chloride } & 50 \\ \text { Phosphate } & 2450 \\ \text { Sulfate } & 900\end{array}$

Figure B - 1. Continued. 
WSRC-STI-2007-00438

SRNL-RPP-2007-00020

HIGH-PURITY STANDARDS

P.O. Box 41727

Charleston, SC 29423

Phone: (843) 767-7900

Fax: $\quad(843) 767-7906$

\section{MATERIAL SAFETY DATA SHEET}

\section{$\underline{S M-744-042}$}

(Standard A)

Issue Date: 04/27/07

SECTION I - Product Identification/Hazardous Ingredients

\begin{tabular}{lll} 
Formula:_N/A Concentration: N/A & Molecular Weight: N/A \\
TSCA: & YES & CAS NO: ${ }^{7697-37-2}$ \\
\hline
\end{tabular}

Component: $5.01 \%$ Multielements including $(0.04 \% \mathrm{Ni})$ in $4 \% \mathrm{HNO}_{3}+$ balance $\mathrm{H}_{2} \mathrm{O}$

TLV/TWA: $8 \mathrm{~h}$ Not Estab.: $5 \mathrm{mg} / \mathrm{m}^{3}$ STEL:_N/A PEL:_N/A Toxicity:_N/A SECTION II - Physical/Chemical Characteristics

Boiling Point: $100^{\circ} \mathrm{C} \quad$ Vapor Pressure $(\mathrm{mm}):$ N/A Vapor Density $(\operatorname{air}+1):$ N/A

Freezing Point:_N/A Specific Gravity $\left(\mathrm{H}_{2} \mathrm{O}=1\right)$ : N/A Solubility in $\mathrm{H}_{2} \mathrm{O}$ : Complete

SECTION III - Fire and Explosion Hazard Data

Flash Point:_ N/A Auto Ignition Temperature: Lower Explosion Level: N/A

NFPA - Rating:_ N/A Extinguishing Media: Use appropriate

Special Fire-Fighting Procedures: Firefighters should wear proper protective equipment and self-contained breathing apparatus with full face piece operated in positive pressure mode.

Unusual Fires Explosion Hazards: N/A

Toxic Gases Produced:

$\mathrm{NO}_{\mathrm{X}}$

Figure B - 2. Standard A Material Data Safety Sheet (MSDS). 
WSRC-STI-2007-00438

SRNL-RPP-2007-00020

SECTION IV - Reacting Data

Unstable: ( ) Stable: $(\mathrm{X})$

Conditions to Avoid: Metals, hydroxides, carbonates, cyanides

Incompatibles: Strong reducing agents

Hazardous Decomposition: $\mathrm{NO}_{\mathrm{x}}$

\section{SECTION V - Health Hazard Data}

Routes of Entry: Inhalation, eye contact, skin contact

Signs and Symptoms of Exposure:__Liquid may cause burns to skin and eyes

Medical Conditions Generally Aggravated by Exposure: _ None identified

Carcinogenicity: NTP: Yes(Ni)_IARC: Yes(Ni) OSHA reg.: Yes(Ni)

Emergency First Aid Procedures:_CALL A PHYSICIAN; If swallowed. do not induce vomiting, if conscious

give water, milk. In case of contact. flush eyes or skin with plenty of water.

SECTION VI - Precautions for Safe Handling and Use

Special Precautions: Keep container tightly closed

In Case of Spill or Discharge: Remove source of ignition if hydrogen is a hazard. Provide optimum

ventilation. Flush to holding area for neutralization.

Disposal Procedures: Follow Federal. State and Local regulations for waste.

SECTION VII - Protective Equipment

Respiratory Protection:_ NIOSH approved respirator

Ventilation: Local Exhaust(X) Mechanical ()

Protective Gloves:__ Proper gloves

Eye Protection: Safety glasses with side shields

Other:_Lab coat/apron: vent hood

NOTICE

The data and information as stated was furnished by the manufacturers/vendors \& or suppliers of this products. High-Purity Standards, Inc. cannot warrant the accuracy of this information and shall not be responsible or liable for any damage that may result, should any of the information be erroneous.

Prepared by: Theodore C Rains, Ph.D 04/27/07

\section{Figure B - 2. Continued}


WSRC-STI-2007-00438

SRNL-RPP-2007-00020

P.O. Box 41727

Charleston, SC 29423

TEL: (843) 767-7900

FAX: (843) 767-7906

\title{
HIGH-PURITY \\ STANDARDS
}

\section{Certificate of Aralpsis}

\author{
SM-744-043 \\ (Standard B) \\ Lot \# 0709521
}

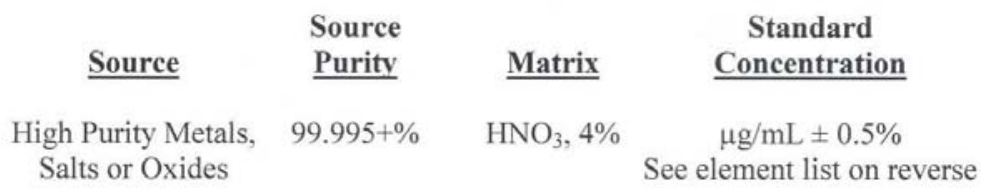

This spectrometric standard solution has been prepared from high-purity reference materials. Sub-boiling distilled high-purity acid has been used to place the materials in solution and to stabilize the standard. The matrix is as noted above in 18 megaohm deionized water. The reference materials have been assayed by inductively coupled plasma optical emission spectrometry (ICP-OES) and ion chromatography (IC).

The standard has been prepared gravimetrically by weighing the reference material to 5 significant figures. Volumetric glassware has been calibrated gravimetrically to 5 significant figures. The standard concentration has been verified by ICP-OES and IC against an independent source which is directly traceable to National Institute of Standards and Technology, Standard Reference Material No. 3100 series.

This standard is valid for three months from the shipping date provided the solution is kept tightly capped and stored under normal laboratory conditions. Expiration date may be extended as stability is determined.

Exp Date:

MSDS ATTACHED

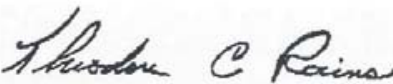

Theodore C. Rains, Ph.D.

President

\section{Figure B - 3. Standard B Certificate of Analysis}


WSRC-STI-2007-00438

SRNL-RPP-2007-00020

SM-744-043

(Standard B)

Element List

$(\mu \mathrm{g} / \mathrm{mL})$

$\begin{array}{lr}\text { Aluminum } & 3650 \\ \text { Calcium } & 5 \\ \text { Chromium } & 85 \\ \text { Molybdenum from }\left(\mathrm{NH}_{4}\right)_{2} \mathrm{MoO}_{4} & 10 \\ \text { Nickel } & 5 \\ \text { Potassium } & 17,000 \\ \text { Sodium } & 64,500 \\ \text { Chloride } & 800 \\ \text { Phosphate } & 650 \\ \text { Sulfate } & 1950\end{array}$

Figure B - 3. Continued. 
WSRC-STI-2007-00438

SRNL-RPP-2007-00020

HIGH-PURITY STANDARDS

P.O. Box 41727

Charleston, SC 29423

Phone: (843) 767-7900

Fax: (843) $767-7906$

\section{MATERIAL SAFETY DATA SHEET}

$\underline{S M-744-043}$

(Standard B)

Issue Date: 4/6/07

SECTION I - Product Identification/Hazardous Ingredients

Formula: N/A YES Concentration: N/A CAS NO: $\quad 7697-37-2$

Component: $8.87 \%$ Multielements including $(0.001 \% \mathrm{Ni})$ in $4 \% \mathrm{HNO}_{3}+$ balance $\mathrm{H}_{2} \mathrm{O}$

TLV/TWA: $8 \mathrm{~h}$ Not Estab: $5 \mathrm{mg} / \mathrm{m}^{3}$

STEL:

N/A PEL: N/A Toxicity: $\mathrm{N} / \mathrm{A}$

SECTION II - Physical/Chemical Characteristics

Boiling Point: $100^{\circ} \mathrm{C}$ Vapor Pressure (mm): N/A Vapor Density (air+1): N/A

Freezing Point: Specific Gravity $\left(\mathrm{H}_{2} \mathrm{O}=1\right)$ : N/A Solubility in $\mathrm{H}_{2} \mathrm{O}$ : Complete

SECTION III - Fire and Explosion Hazard Data

Flash Point: N/A Auto Ignition Temperature:

N/A Lower Explosion Level: N/A

NFPA - Rating: N/A Extinguishing Media: Use appropriate

Special Fire-Fighting Procedures: Firefighters should wear proper protective equipment and self-contained breathing apparatus with full face piece operated in positive pressure mode.

Unusual Fires Explosion Hazards: N/A

Toxic Gases Produced:

$\mathrm{NO}_{\mathrm{X}}$

Figure B - 4. Standard B Material Data Safety Sheet (MSDS). 
WSRC-STI-2007-00438

SRNL-RPP-2007-00020

SECTION IV - Reacting Data

Unstable: ( ) Stable: $(\mathrm{X})$

Conditions to Avoid: Metals, hydroxides, carbonates, cyanides

Incompatibles:_ Strong reducing agents

Hazardous Decomposition: $\mathrm{NO}$

\section{SECTION V - Health Hazard Data}

Routes of Entry:_Inhalation. eye contact, skin contact

Signs and Symptoms of Exposure:_Liquid may cause burns to skin and eyes

Medical Conditions Generally Aggravated by Exposure:_None identified

Carcinogenicity: NTP: Yes(Ni)_ IARC: Yes(Ni)_OSHA reg.: Yes(Ni)

Emergency First Aid Procedures: CALL A PHYSICIAN; If swallowed, do not induce vomiting, if conscious give water, milk. In case of contact. flush eyes or skin with plenty of water.

SECTION VI - Precautions for Safe Handling and Use

Special Precautions: Keep container tightly closed

In Case of Spill or Discharge: Remove source of ignition if hydrogen is a hazard. Provide optimum

ventilation. Flush to holding area for neutralization.

Disposal Procedures:_Follow Federal. State and Local regulations for waste.

\section{SECTION VII - Protective Equipment}

Respiratory Protection:_ NIOSH approved respirator

Ventilation: Local Exhaust(X) Mechanical ()

Protective Gloves:_ Proper gloves

Eye Protection: Safety glasses with side shields

Other:_L Lab coat/apron: vent hood

\section{NOTICE}

The data and information as stated was furnished by the manufacturers/vendors \& or suppliers of this products. High-Purity Standards, Inc. cannot warrant the accuracy of this information and shall not be responsible or liable for any damage that may result, should any of the information be erroneous.

Prepared by: Theodore C Rains, Ph.D 4/6/07

\section{Figure B - 4. Continued.}


WSRC-STI-2007-00438

SRNL-RPP-2007-00020

P.O. Box 41727

Charleston, SC 29423

TEL: (843) 767-7900

FAX: (843) 767-7906

\title{
HIGH-PURITY
}

STANDARDS

\section{Certificate of Analysis}

\author{
SM-744-044 \\ (Standard C) \\ Lot \# 0710007 \\ $\underline{\text { Source }} \quad \begin{array}{ll}\text { Source } \\ \text { Purity }\end{array} \quad \underline{\text { Matrix }} \quad \underline{\begin{array}{c}\text { Standard } \\ \text { Concentration }\end{array}}$ \\ High Purity Metals, $\quad 99.997+\% \quad \mathrm{HNO}_{3}, 4 \% \quad \mu \mathrm{g} / \mathrm{mL} \pm 0.5 \%$ \\ Salts or Oxides See element list on reverse
}

This spectrometric standard solution has been prepared from high-purity reference materials. Sub-boiling distilled high-purity acid has been used to place the materials in solution and to stabilize the standard. The matrix is as noted above in 18 megaohm deionized water. The reference materials have been assayed by inductively coupled plasma optical emission spectrometry (ICP-OES) and ion chromatography (IC).

The standard has been prepared gravimetrically by weighing the reference material to 5 significant figures. Volumetric glassware has been calibrated gravimetrically to 5 significant figures. The standard concentration has been verified by ICP-OES and IC against an independent source which is directly traceable to National Institute of Standards and Technology, Standard Reference Material No. 3100 series.

This standard is valid for three months from the shipping date provided the solution is kept tightly capped and stored under normal laboratory conditions. Expiration date may be extended as stability is determined.

Exp Date:

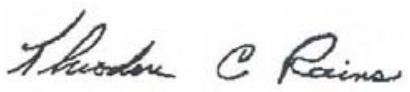

MSDS ATTACHED

Theodore C. Rains, Ph.D.

President

Issue date: MAY 082007

\section{Figure B - 5. Standard C Certificate of Analysis.}


WSRC-STI-2007-00438

SRNL-RPP-2007-00020

SM-744-044

(Standard C)

Element List

$(\mu \mathrm{g} / \mathrm{mL})$

$\begin{array}{lr}\text { Aluminum } & 9500 \\ \text { Calcium } & 125 \\ \text { Chromium } & 400 \\ \text { Molybdenum from }\left(\mathrm{NH}_{4}\right)_{2} \mathrm{MoO}_{4} & 50 \\ \text { Nickel } & 130 \\ \text { Potassium } & 2400 \\ \text { Sodium } & 62,000 \\ \text { Chloride } & 135 \\ \text { Phosphate } & 1050 \\ \text { Sulfate } & 9650\end{array}$

Figure B - 5. Continued. 
WSRC-STI-2007-00438

SRNL-RPP-2007-00020

HIGH-PURITY STANDARDS

P.O. Box 41727

Charleston, SC 29423

Phone: (843) 767-7900

Fax: $\quad(843) 767-7906$

\section{MATERIAL SAFETY DATA SHEET}

$\underline{S M-744-044}$

(Standard C)

Issue Date: 04/27/07

SECTION I - Product Identification/Hazardous Ingredients

Formula: N/A Concentration: N/A CAS NO: $\quad 7697-37-2$

Component: $8.54 \%$ Multielements including $(0.013 \% \mathrm{Ni})$ in $4 \% \mathrm{HNO}_{3}+$ balance $\mathrm{H}_{2} \mathrm{O}$

TLV/TWA: $8 \mathrm{~h}$ Not Estab.: $5 \mathrm{mg} / \mathrm{m}^{3}$

STEL: N/A PEL: N/A Toxicity: N/A

SECTION II - Physical/Chemical Characteristics

Boiling Point: $100^{\circ} \mathrm{C}$ Vapor Pressure (mm): N/A Vapor Density (air+1): N/A

Freezing Point: N/A Specific Gravity $\left(\mathrm{H}_{2} \mathrm{O}=1\right)$ : N/A Solubility in $\mathrm{H}_{2} \mathrm{O}$ : Complete

SECTION III - Fire and Explosion Hazard Data

Flash Point: N/A Auto Ignition Temperature:

N/A Lower Explosion Level: N/A

NFPA - Rating:_ N/A Extinguishing Media: Use appropriate

Special Fire-Fighting Procedures: Firefighters should wear proper protective equipment and self-contained breathing apparatus with full face piece operated in positive pressure mode.

Unusual Fires Explosion Hazards:_ N/A

Toxic Gases Produced: $\quad \mathrm{NO}_{\mathrm{X}}$

\section{Figure B - 6. Standard C Material Data Safety Sheet (MSDS).}


WSRC-STI-2007-00438

SRNL-RPP-2007-00020

SECTION IV - Reacting Data

Unstable: ( ) Stable: (X)

Conditions to Avoid: Metals, hydroxides, carbonates, cyanides

Incompatibles: Strong reducing agents

Hazardous Decomposition: $\mathrm{NO}_{\mathrm{X}}$

SECTION V - Health Hazard Data

Routes of Entry:_ Inhalation, eye contact, skin contact

Signs and Symptoms of Exposure:_Liquid may cause burns to skin and eyes

Medical Conditions Generally Aggravated by Exposure: None identified

Carcinogenicity: NTP: Yes(Ni)_IARC: Yes(Ni)_OSHA reg.: Yes(Ni)

Emergency First Aid Procedures:_CALL A PHYSICIAN; If swallowed, do not induce vomiting, if conscious

give water. milk. In case of contact. flush eyes or skin with plenty of water.

SECTION VI - Precautions for Safe Handling and Use

Special Precautions: Keep container tightly closed

In Case of Spill or Discharge: Remove source of ignition if hydrogen is a hazard. Provide optimum

ventilation. Flush to holding area for neutralization.

Disposal Procedures: Follow Federal. State and Local regulations for waste.

SECTION VII - Protective Equipment

Respiratory Protection:_ NIOSH approved respirator

Ventilation: Local Exhaust(X) Mechanical ()

Protective Gloves:_ Proper gloves

Eye Protection: Safety glasses with side shields

Other:_Lab coat/apron; vent hood

\section{NOTICE}

The data and information as stated was furnished by the manufacturers/vendors \& or suppliers of this products. High-Purity Standards, Inc. cannot warrant the accuracy of this information and shall not be responsible or liable for any damage that may result, should any of the information be erroneous.

Prepared by: Theodore C Rains, Ph.D 04/27/07

\section{Figure B - 6. Continued.}


WSRC-STI-2007-00438

SRNL-RPP-2007-00020

P.O. Box 41727

Charleston, SC 29423

TEL: (843) 767-7900

FAX: (843) 767-7906

\title{
HIGH-PURITY
}

STANDARDS

\section{Certificate of Analysis}

\author{
SM-744-045 \\ (Standard D) \\ Lot \# 0710008
}

$\begin{array}{cccc}\text { Source } & \begin{array}{c}\text { Source } \\ \text { Purity }\end{array} & \text { Matrix } & \begin{array}{c}\text { Standard } \\ \text { Concentration }\end{array} \\ \begin{array}{cccc}\text { High Purity Metals, } \\ \text { Salts or Oxides }\end{array} & 99.995+\% & \mathrm{HNO}_{3}, 4 \% & \begin{array}{c}\mu \mathrm{g} / \mathrm{mL} \pm 0.5 \% \\ \text { See element list on reverse }\end{array}\end{array}$

This spectrometric standard solution has been prepared from high-purity reference materials. Sub-boiling distilled high-purity acid has been used to place the materials in solution and to stabilize the standard. The matrix is as noted above in 18 megaohm deionized water. The reference materials have been assayed by inductively coupled plasma optical emission spectrometry (ICP-OES) and ion chromatography (IC).

The standard has been prepared gravimetrically by weighing the reference material to 5 significant figures. Volumetric glassware has been calibrated gravimetrically to 5 significant figures. The standard concentration has been verified by ICP-OES and IC against an independent source which is directly traceable to National Institute of Standards and Technology, Standard Reference Material No. 3100 series.

This standard is valid for three months from the shipping date provided the solution is kept tightly capped and stored under normal laboratory conditions. Expiration date may be extended as stability is determined.

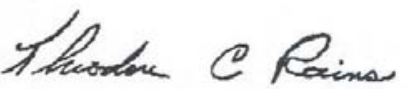

Exp Date:

Theodore C. Rains, Ph.D.

MSDS ATTACHED

President

ISSUE DATE: MAY 082007

Figure B - 7. Standard D Certificate of Analysis. 
WSRC-STI-2007-00438

SRNL-RPP-2007-00020

\section{SM-744-045}

(Standard D)

\section{Element List} $(\mu \mathrm{g} / \mathrm{mL})$

$\begin{array}{lr}\text { Aluminum } & 9600 \\ \text { Calcium } & 400 \\ \text { Chromium } & 900 \\ \text { Molybdenum from }\left(\mathrm{NH}_{4}\right)_{2} \mathrm{MoO}_{4} & 60 \\ \text { Nickel } & 750 \\ \text { Potassium } & 3400 \\ \text { Sodium } & 65,800 \\ \text { Chloride } & 70 \\ \text { Phosphate } & 750 \\ \text { Sulfate } & 19,000\end{array}$

Figure B - 7. Continued. 
WSRC-STI-2007-00438

SRNL-RPP-2007-00020

HIGH-PURITY STANDARDS

P.O. Box 41727

Charleston, SC 29423

Phone: (843) 767-7900

Fax: $\quad(843) 767-7906$

\section{MATERIAL SAFETY DATA SHEET}

$\underline{S M-744-045}$

(Standard D)

Issue Date: $04 / 27 / 07$

SECTION I - Product Identification/Hazardous Ingredients

Formula: Concentration: N/A Molecular Weight: N/A

TSCA: YES CAS NO: $\quad 7697-37-2$

Component: $10.07 \%$ Multielements including $(0.08 \% \mathrm{Ni})$ in $4 \% \mathrm{HNO}_{3}+$ balance $\mathrm{H}_{2} \mathrm{O}$

TLV/TWA: $8 \mathrm{~h}$ Not Estab.: $5 \mathrm{mg} / \mathrm{m}^{3}$

STEL: N/A PEL: N/A Toxicity: N/A

SECTION II - Physical/Chemical Characteristics

Boiling Point: $100^{\circ} \mathrm{C}$ Vapor Pressure (mm): N/A Vapor Density (air+1): N/A

Freezing Point: Specific Gravity $\left(\mathrm{H}_{2} \mathrm{O}=1\right)$ : N/A Solubility in $\mathrm{H}_{2} \mathrm{O}$ : Complete

SECTION III - Fire and Explosion Hazard Data

Flash Point:_ N/A Auto Ignition Temperature: Lower Explosion Level: N/A

NFPA - Rating:_ N/A Extinguishing Media:_Use appropriate

Special Fire-Fighting Procedures: Firefighters should wear proper protective equipment and self-contained breathing apparatus with full face piece operated in positive pressure mode.

Unusual Fires Explosion Hazards: N/A

Toxic Gases Produced: $\quad \mathrm{NO}_{\mathrm{X}}$

Figure B - 8. Standard D Material Data Safety Sheet (MSDS). 
WSRC-STI-2007-00438

SRNL-RPP-2007-00020

SECTION IV - Reacting Data

Unstable: ( ) Stable: (X)

Conditions to Avoid: Metals, hydroxides, carbonates, cyanides

Incompatibles: Strong reducing agents

Hazardous Decomposition: $\mathrm{NO}_{\mathrm{X}}$

SECTION V - Health Hazard Data

Routes of Entry:_Inhalation, eye contact. skin contact

Signs and Symptoms of Exposure:_Liquid may cause burns to skin and eyes

Medical Conditions Generally Aggravated by Exposure:_None identified

Carcinogenicity: NTP: Yes(Ni)_IARC: Yes(Ni)_OSHA reg.: Yes(Ni)

Emergency First Aid Procedures: CALL A PHYSICIAN: If swallowed, do not induce vomiting, if conscious

give water, milk. In case of contact, flush eyes or skin with plenty of water.

SECTION VI - Precautions for Safe Handling and Use

Special Precautions: Keep container tightly closed

In Case of Spill or Discharge:_Remove source of ignition if hydrogen is a hazard. Provide optimum

ventilation. Flush to holding area for neutralization.

Disposal Procedures: Follow Federal, State and Local regulations for waste.

SECTION VII - Protective Equipment

Respiratory Protection:_ NIOSH approved respirator

Ventilation: Local Exhaust(X) Mechanical ()

Protective Gloves:__ Proper gloves

Eye Protection: Safety glasses with side shields

Other:_Lab coat/apron; vent hood

NOTICE

The data and information as stated was furnished by the manufacturers/vendors \& or suppliers of this products. High-Purity Standards, Inc. cannot warrant the accuracy of this information and shall not be responsible or liable for any damage that may result, should any of the information be erroneous. Prepared by: Theodore C Rains, Ph.D 04/27/07

\section{Figure B - 8. Continued.}


WSRC-STI-2007-00438

SRNL-RPP-2007-00020

P.O. Box 41727

Charleston, SC 29423

TEL: (843) 767-7900

FAX: (843) 767-7906

\title{
HIGH-PURITY
}

STANDARDS

\section{Certificate of Analysis}

\author{
SM-744-046 \\ (Standard E) \\ Lot \# 0709602
}

$\begin{array}{cccc}\text { Source } & \begin{array}{c}\text { Source } \\ \text { Purity }\end{array} & \underline{\text { Matrix }} & \begin{array}{c}\text { Standard } \\ \text { Concentration }\end{array} \\ \begin{array}{cccc}\text { High Purity Metals, } \\ \text { Salts or Oxides }\end{array} & 99.995+\% & \mathrm{HNO}_{3}, 4 \% & \begin{array}{c}\mu \mathrm{g} / \mathrm{mL} \pm 0.5 \% \\ \text { See element list on reverse }\end{array}\end{array}$

This spectrometric standard solution has been prepared from high-purity reference materials. Sub-boiling distilled high-purity acid has been used to place the materials in solution and to stabilize the standard. The matrix is as noted above in 18 megaohm deionized water. The reference materials have been assayed by inductively coupled plasma optical emission spectrometry (ICP-OES) and ion chromatography (IC).

The standard has been prepared gravimetrically by weighing the reference material to 5 significant figures. Volumetric glassware has been calibrated gravimetrically to 5 significant figures. The standard concentration has been verified by ICP-OES and IC against an independent source which is directly traceable to National Institute of Standards and Technology, Standard Reference Material No. 3100 series.

This standard is valid for three months from the shipping date provided the solution is kept tightly capped and stored under normal laboratory conditions. Expiration date may be extended as stability is determined.

Exp Date:

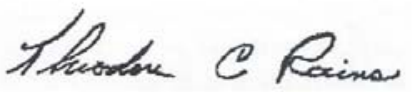

Theodore C. Rains, Ph.D.

MSDS ATTACHED

President

ISSUE DATE:

MAY 082007

Figure B - 9. Standard E Certificate of Analysis. 
WSRC-STI-2007-00438

SRNL-RPP-2007-00020

SM-744-046 (Standard E) Element List

$$
(\mu \mathrm{g} / \mathrm{mL})
$$

$\begin{array}{lr}\text { Aluminum } & 9150 \\ \text { Calcium } & 40 \\ \text { Chromium } & 300 \\ \text { Molybdenum from }\left(\mathrm{NH}_{4}\right)_{2} \mathrm{MoO}_{4} & 30 \\ \text { Nickel } & 40 \\ \text { Potassium } & 3250 \\ \text { Sodium } & 89000 \\ \text { Chloride } & 2150 \\ \text { Phosphate } & 1200 \\ \text { Sulfate } & 2400\end{array}$

Figure B - 9. Continued. 
WSRC-STI-2007-00438

SRNL-RPP-2007-00020

HIGH-PURITY STANDARDS

P.O. Box 41727

Charleston, SC 29423

Phone: (843) 767-7900

Fax: $\quad(843) 767-7906$

\title{
MATERIAL SAFETY DATA SHEET
}

\author{
SM-744-046 \\ (Standard E)
}

\begin{abstract}
Issue Date: 4 4/6/07
SECTION I - Product Identification/Hazardous Ingredients

Formula: Concentration: N/A Molecular Weight: N/A

TSCA: YES CAS NO: $\quad 7697-37-2$

Component: $10.76 \%$ Multielements including $(0.004 \% \mathrm{Ni})$ in $4 \% \mathrm{HNO}_{3}+$ balance $\mathrm{H}_{2} \mathrm{O}$ PEL: N/A Toxicity: N/A

SECTION II - Physical/Chemical Characteristics

Boiling Point: $100^{\circ} \mathrm{C}$ Vapor Pressure (mm): N/A Vapor Density (air+1): N/A

Freezing Point: Specific Gravity $\left(\mathrm{H}_{2} \mathrm{O}=1\right)$ : N/A Solubility in $\mathrm{H}_{2} \mathrm{O}$ : Complete

SECTION III - Fire and Explosion Hazard Data

Flash Point: N/A Auto Ignition Temperature: Lower Explosion Level:_ N/A

NFPA - Rating:_ N/A Extinguishing Media:_Use appropriate

Special Fire-Fighting Procedures: Firefighters should wear proper protective equipment and self-contained breathing apparatus with full face piece operated in positive pressure mode.

Unusual Fires Explosion Hazards: N/A

Toxic Gases Produced:

$\mathrm{NO}_{\mathrm{x}}$
\end{abstract}

Figure B - 10. Standard E Material Data Safety Sheet (MSDS). 
WSRC-STI-2007-00438

SRNL-RPP-2007-00020

SECTION IV - Reacting Data

Unstable: () Stable: $(\mathrm{X})$

Conditions to Avoid: Metals, hydroxides, carbonates, cyanides

Incompatibles: Strong reducing agents

Hazardous Decomposition: $\mathrm{NO}_{\mathrm{X}}$

SECTION V - Health Hazard Data

Routes of Entry:_ Inhalation, eye contact, skin contact

Signs and Symptoms of Exposure:_Liquid may cause burns to skin and eyes

Medical Conditions Generally Aggravated by Exposure:_None identified

Carcinogenicity: NTP: Yes(Ni)_IARC: Yes(Ni)_OSHA reg.: Yes(Ni)

Emergency First Aid Procedures: CALL A PHYSICIAN; If swallowed, do not induce vomiting, if conscious

give water, milk. In case of contact. flush eyes or skin with plenty of water.

SECTION VI - Precautions for Safe Handling and Use

Special Precautions: Keep container tightly closed

In Case of Spill or Discharge:_Remove source of ignition if hydrogen is a hazard. Provide optimum

ventilation. Flush to holding area for neutralization.

Disposal Procedures:_Follow Federal. State and Local regulations for waste.

SECTION VII - Protective Equipment

Respiratory Protection:_ NIOSH approved respirator

Ventilation: Local Exhaust $(\mathrm{X}) \quad$ Mechanical ()

Protective Gloves:__ Proper gloves

Eye Protection: Safety glasses with side shields

Other:_Lab coat/apron: vent hood

NOTICE

The data and information as stated was furnished by the manufacturers/vendors \& or suppliers of this products. High-Purity Standards, Inc. cannot warrant the accuracy of this information and shall not be responsible or liable for any damage that may result, should any of the information be erroneous. Prepared by: Theodore C Rains, Ph.D 4/6/07

\section{Figure B - 10. Continued.}


WSRC-STI-2007-00438

SRNL-RPP-2007-00020

\subsection{Appendix C: Precision}

\section{Table C - 1. AN-105 Simulant Solution Precision - Three Runs of Ten Filtered Undiluted Samples in Autosampler from Previous Report ${ }^{1}$.}

Three consecutive runs with samples in same position on autosampler.

$\begin{aligned} \text { Voltage: } & 40-\mathrm{kV} \quad \text { Current: } 1.2-\mathrm{mA} \\ \text { Atmosphere: } & \mathrm{He}(99.99 \%) \\ \text { Cell: } & \text { Ultralene }-4-\mu \mathrm{mm} \text { (film was not replaced) } \\ \text { Instrument Film: } & \text { Ilmen end } \\ \text { Sample film } & \text { Ultralene }-4-\mu \mathrm{m} \text { (same film for each run) } \\ \text { Cover film: } & \text { Micro-porous Teflon }(0.2-\mu \mathrm{m} \text { pores) } \\ \text { Analysis Time: } & 200-\mathrm{sec} \text { on peak; } 100-\mathrm{sec} \text { on background } \\ \text { Volume: } & 5-\mathrm{mL} \text { filtered supernate }\end{aligned}$

Background Subtracted Intensities

\begin{tabular}{|c|c|c|c|c|c|c|}
\hline & $\begin{array}{l}\mathrm{Na} \\
\mathrm{cps}\end{array}$ & $\begin{array}{c}\text { Al } \\
\text { cps }\end{array}$ & $\begin{array}{c}\mathbf{P} \\
\text { cps }\end{array}$ & $\begin{array}{c}\text { Cl } \\
\text { Cps }\end{array}$ & $\begin{array}{c}\mathrm{K} \\
\text { cps }\end{array}$ & $\begin{array}{l}\text { Cr } \\
\text { cps }\end{array}$ \\
\hline Water Blank & 2.35 & 1.53 & 0.36 & 5.97 & 6.70 & 7.05 \\
\hline A & 228.31 & 713.84 & 7.73 & 1345.48 & 729.79 & 227.10 \\
\hline $\mathrm{B}$ & 224.78 & 715.37 & 7.91 & 1342.49 & 717.28 & 225.93 \\
\hline $\mathrm{C}$ & 230.14 & 720.48 & 7.75 & 1345.21 & 729.07 & 225.67 \\
\hline $\mathrm{D}$ & 224.44 & 713.26 & 7.87 & 1343.36 & 728.17 & 223.47 \\
\hline $\mathrm{E}$ & 226.58 & 709.66 & 7.73 & 1338.60 & 728.07 & 225.98 \\
\hline $\mathrm{F}$ & 228.09 & 717.91 & 7.95 & 1346.95 & 730.99 & 221.67 \\
\hline G & 219.66 & 707.87 & 8.02 & 1337.66 & 724.79 & 224.14 \\
\hline $\mathrm{H}$ & 223.15 & 713.09 & 8.00 & 1340.07 & 726.84 & 225.44 \\
\hline I & 215.13 & 706.30 & 8.26 & 1336.63 & 729.60 & 226.97 \\
\hline $\mathbf{J}$ & 223.35 & 710.05 & 8.07 & 1336.20 & 725.27 & 224.54 \\
\hline A & 221.22 & 712.06 & 7.98 & 1338.18 & 729.03 & 224.89 \\
\hline $\mathrm{B}$ & 215.55 & 702.64 & 8.12 & 1336.31 & 728.54 & 224.17 \\
\hline $\mathrm{C}$ & 220.97 & 704.87 & 7.89 & 1337.58 & 726.95 & 226.08 \\
\hline $\mathrm{D}$ & 213.27 & 698.91 & 7.83 & 1334.54 & 726.99 & 223.70 \\
\hline $\mathrm{E}$ & 212.28 & 696.21 & 7.30 & 1336.40 & 726.35 & 225.85 \\
\hline $\mathrm{F}$ & 217.27 & 707.02 & 7.81 & 1339.21 & 728.88 & 223.06 \\
\hline G & 210.62 & 691.90 & 7.43 & 1330.60 & 726.53 & 223.37 \\
\hline $\mathrm{H}$ & 211.47 & 698.83 & 7.75 & 1335.54 & 724.27 & 223.72 \\
\hline I & 210.47 & 696.08 & 7.60 & 1331.03 & 720.71 & 229.36 \\
\hline $\mathrm{J}$ & 212.37 & 696.44 & 7.40 & 1337.86 & 714.17 & 226.70 \\
\hline A & 202.32 & 689.23 & 7.95 & 1334.52 & 706.14 & 226.34 \\
\hline B & 197.75 & 678.16 & 8.07 & 1334.56 & 696.64 & 224.46 \\
\hline $\mathrm{C}$ & 197.37 & 679.25 & 8.16 & 1330.42 & 688.78 & 224.98 \\
\hline $\mathrm{D}$ & 197.59 & 669.79 & 7.94 & 1336.21 & 682.16 & 223.30 \\
\hline $\mathrm{E}$ & 194.48 & 667.58 & 8.04 & 1333.45 & 674.70 & 223.42 \\
\hline $\mathrm{F}$ & 194.62 & 667.29 & 7.57 & 1333.20 & 675.12 & 222.35 \\
\hline G & 189.69 & 658.49 & 8.17 & 1331.25 & 663.52 & 222.45 \\
\hline $\mathrm{H}$ & 199.91 & 673.79 & 7.74 & 1326.79 & 657.33 & 223.25 \\
\hline I & 201.05 & 667.25 & 7.77 & 1331.88 & 653.06 & 221.51 \\
\hline $\mathrm{J}$ & 202.43 & 669.14 & 7.69 & 1333.43 & 651.09 & 223.53 \\
\hline Average & 212.2 & 695.1 & 7.9 & 1336.5 & 709.0 & 224.6 \\
\hline Stdev & 11.9 & 18.5 & 0.2 & 4.8 & 26.9 & 1.8 \\
\hline \% RSD & 5.6 & 2.7 & 3.0 & 0.4 & 3.8 & 0.8 \\
\hline
\end{tabular}

${ }^{1}$ This Table is from A. R. Jurgensen, D. M. Missimer, and R. L. Rutherford,

"X-ray Fluorescence (XRF) Aanalysis of Hanford Low Activity Waste Simulants",

WSRC-TR-2006-00137, SRNL-RPP-2006-00019. 
WSRC-STI-2007-00438

SRNL-RPP-2007-00020

\section{Table C - 2. AN-105 Simulant Solution ${ }^{1}$ Precision - Three Runs of Five Filtered Diluted Samples (1:1) in Autosampler.}

Three consecutive runs with samples in same position on autosampler.

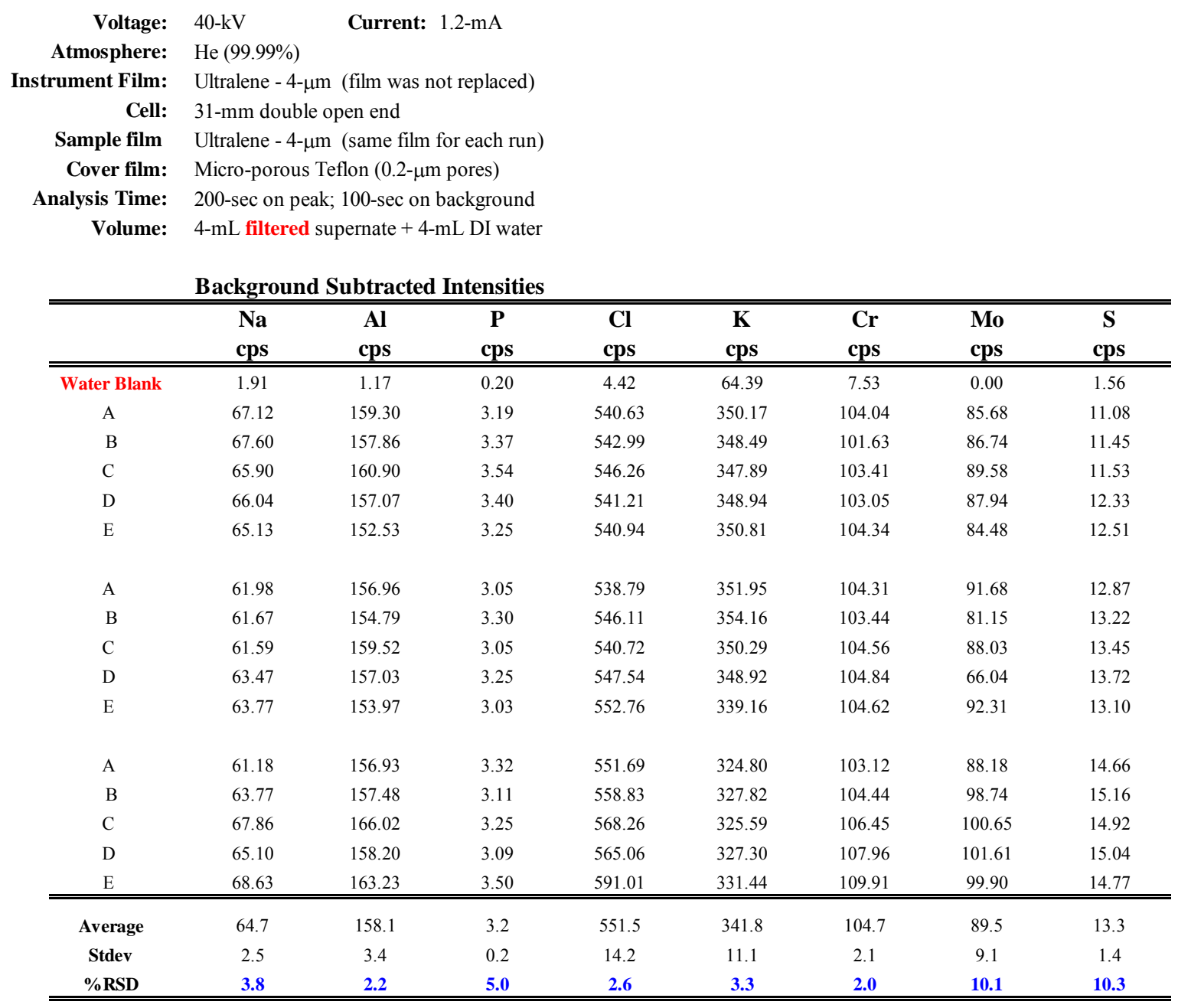

${ }^{1}$ Simulant AN-105 was made using the full Eibling recipe and diluted to $5 \mathrm{M}$ sodium. 
WSRC-STI-2007-00438

SRNL-RPP-2007-00020

\section{Table C - 3. AN-105 Simulant Solution ${ }^{1}$ Precision - Fourteen Runs of One Filtered Diluted Sample (1:1) in Autosampler over 8 Hours.}

One sample in same position on autosampler run 14 times over 8 hours.

\begin{tabular}{|c|c|c|c|c|c|c|}
\hline Voltage: & $40-\mathrm{kV}$ & \multicolumn{2}{|c|}{ Current: $1.2-\mathrm{mA}$} & & & \\
\hline Atmosphere: & \multicolumn{6}{|c|}{$\mathrm{He}(99.99 \%)$} \\
\hline Instrument Film: & \multicolumn{6}{|c|}{ Ultralene - 4- $\mu \mathrm{m}$ (film was not replaced) } \\
\hline Cell: & \multicolumn{6}{|c|}{ 31-mm double open end } \\
\hline Sample film & \multicolumn{6}{|c|}{ Ultralene - 4- $\mu \mathrm{m}$ (same film for each run) } \\
\hline Cover film: & \multicolumn{6}{|c|}{ Micro-porous Teflon $(0.2-\mu \mathrm{m}$ pores $)$} \\
\hline Analysis Time: & \multicolumn{6}{|c|}{200 -sec on peak; 100 -sec on background } \\
\hline Volume: & \multicolumn{6}{|c|}{ 4-mL filtered supernate +4 -mL DI water } \\
\hline & \multicolumn{6}{|c|}{ Background Subtracted Intensities } \\
\hline & $\mathrm{Na}$ & Al & $\mathbf{P}$ & $\mathbf{C l}$ & $\mathbf{K}$ & $\mathrm{Cr}$ \\
\hline & cps & cps & cps & cps & cps & cps \\
\hline & 63.27 & 153.96 & 3.09 & 557.87 & 353.44 & 111.31 \\
\hline & 65.26 & 155.18 & 3.33 & 548.84 & 348.34 & 107.34 \\
\hline & 64.21 & 153.18 & 3.24 & 546.15 & 346.77 & 106.36 \\
\hline & 62.39 & 152.87 & 3.10 & 540.24 & 348.76 & 103.06 \\
\hline & 63.80 & 151.08 & 3.26 & 542.19 & 348.61 & 104.68 \\
\hline & 61.30 & 153.08 & 3.34 & 545.71 & 352.47 & 103.74 \\
\hline & 62.07 & 153.31 & 3.36 & 543.72 & 354.63 & 103.55 \\
\hline & 62.06 & 153.29 & 3.56 & 550.08 & 357.41 & 105.63 \\
\hline & 61.33 & 151.48 & 3.45 & 549.48 & 357.92 & 105.82 \\
\hline & 58.90 & 150.92 & 3.13 & 546.09 & 357.46 & 106.40 \\
\hline & 58.56 & 151.06 & 2.89 & 548.60 & 359.67 & 106.20 \\
\hline & 57.37 & 149.82 & 3.36 & 550.67 & 357.58 & 108.49 \\
\hline & 57.50 & 147.97 & 3.38 & 549.93 & 357.06 & 106.86 \\
\hline & 54.57 & 147.74 & 2.76 & 548.69 & 361.43 & 106.65 \\
\hline Average & 61.2 & 151.8 & 3.2 & 547.7 & 354.3 & 106.2 \\
\hline Stdev & 3.2 & 2.3 & 0.2 & 4.5 & 5.0 & 2.1 \\
\hline \%RSD & 5.2 & 1.5 & 7.2 & 0.8 & 1.4 & 2.0 \\
\hline
\end{tabular}

${ }^{1}$ Simulant AN-105 was made using the full Eibling recipe and diluted to $5 \mathrm{M}$ sodium. 
WSRC-STI-2007-00438

SRNL-RPP-2007-00020

Table C - 4. AN-105 Simulant Solution ${ }^{1}$ Precision - One Filtered Diluted Sample (1:1) in Autosampler Run at Different Times During the Day.

One sample in same position on autosampler run at different times during the day.

\begin{tabular}{|c|c|c|c|c|c|c|}
\hline & & & & & & \\
\hline Atmosphere: & $\mathrm{He}(99.99 \%)$ & & & & & \\
\hline Instrument Film: & Ultralene - 4- & $\mathrm{mm}$ (film $\mathrm{v}$ & as not replaced) & & & \\
\hline Cell: & 31-mm doubl & e open end & & & & \\
\hline Sample film & Ultralene - 4- & mm (same & ilm for each run) & & & \\
\hline Cover film: & Micro-porous & Teflon $(0.2$ & -mm pores) & & & \\
\hline Analysis Time: & $200-\sec$ on pe & eak; $100-\mathrm{sec}$ & on background & & & \\
\hline Volume: & 4-mL filtered & supernate & 4-mL DI water & & & \\
\hline & Backgroun & d Subtract & ed Intensities & & & \\
\hline Time & $\begin{array}{l}\mathrm{Na} \\
\mathrm{cps}\end{array}$ & $\begin{array}{c}\text { Al } \\
\text { cps }\end{array}$ & $\begin{array}{c}\mathbf{P} \\
\text { cps }\end{array}$ & $\begin{array}{c}\mathrm{Cl} \\
\mathrm{cps}\end{array}$ & $\begin{array}{c}\mathrm{K} \\
\text { cps }\end{array}$ & $\begin{array}{l}\mathrm{Cr} \\
\mathrm{cps}\end{array}$ \\
\hline intial & 60.77 & 150.02 & 3.53 & 536.48 & 345.51 & 105.08 \\
\hline 2-hrs & 65.08 & 157.04 & 3.36 & 539.27 & 348.94 & 104.27 \\
\hline 4-hrs & 65.76 & 157.49 & 3.42 & 546.86 & 350.77 & 103.65 \\
\hline 5-hrs & 65.14 & 158.04 & 3.17 & 550.35 & 354.96 & 105.84 \\
\hline 6-hrs & 65.20 & 158.05 & 3.39 & 557.2 & 357.94 & 106.18 \\
\hline Average & 64.4 & 156.1 & 3.4 & 546.0 & 351.6 & 105.0 \\
\hline Stdev & 2.0 & 3.4 & 0.1 & 8.4 & 4.9 & 1.1 \\
\hline$\%$ RSD & 3.2 & 2.2 & 3.9 & 1.5 & 1.4 & 1.0 \\
\hline
\end{tabular}

* The instrument film and sample film were exposed to the x-ray beam for 2.5 hours.

${ }^{1}$ Simulant AN-105 was made using the full Eibling recipe and diluted to $5 \mathrm{M}$ sodium. 
WSRC-STI-2007-00438

SRNL-RPP-2007-00020

Table C - 5. AN-105 Simulant Solution ${ }^{1}$ Precision - Three Runs of Five Filtered Diluted Samples (1:1) in Autosampler with the Instrument Film Replaced Prior to Each Run.

Three consecutive runs with samples in same position on autosampler

\begin{tabular}{|c|c|c|c|c|c|c|}
\hline Voltage: & $40-\mathrm{kV}$ & \multicolumn{2}{|c|}{ Current: $1.2-\mathrm{mA}$} & & & \\
\hline $\begin{array}{l}\text { Atmosphere: } \\
\text { Instrument Film. }\end{array}$ & \multicolumn{6}{|c|}{ He $(99.99 \%)$} \\
\hline Instrument Film: & \multicolumn{6}{|c|}{ Ultralene - 4- $\mu \mathrm{m}$ (film was replaced prior to each run) } \\
\hline Cell: & \multicolumn{6}{|c|}{ 31-mm double open end } \\
\hline Sample film & \multicolumn{6}{|c|}{ Ultralene - 4- $\mu \mathrm{m}$ (same film for each run) } \\
\hline Cover film: & \multicolumn{6}{|c|}{ Micro-porous Teflon $(0.2-\mu \mathrm{m}$ pores $)$} \\
\hline Analysis Time: & \multirow{2}{*}{\multicolumn{6}{|c|}{200 -sec on peak; 100 -sec on background }} \\
\hline Volume: & \multicolumn{5}{|c|}{ 4-mL filtered supernate $+4-\mathrm{mL}$ DI water } & \\
\hline & \multicolumn{6}{|c|}{ Background Subtracted Intensities } \\
\hline & $\mathbf{N a}$ & Al & $\mathbf{P}$ & Cl & $\mathbf{K}$ & $\mathrm{Cr}$ \\
\hline & cps & cps & cps & cps & cps & cps \\
\hline A & 68.38 & 160.36 & 3.12 & 553.35 & 353.39 & 106.31 \\
\hline B & 69.07 & 164.94 & 3.51 & 556.26 & 354.55 & 108.19 \\
\hline $\mathrm{C}$ & 65.08 & 154.39 & 3.16 & 540.44 & 347.20 & 104.48 \\
\hline $\mathrm{D}$ & 66.05 & 153.23 & 3.56 & 536.50 & 346.44 & 104.99 \\
\hline E & 65.20 & 154.51 & 3.46 & 545.85 & 349.36 & 105.53 \\
\hline A & 64.67 & 151.61 & 3.63 & 537.00 & 349.76 & 104.28 \\
\hline B & 66.02 & 162.41 & 3.58 & 548.19 & 353.63 & 105.49 \\
\hline $\mathrm{C}$ & 65.07 & 157.57 & 3.15 & 542.27 & 351.84 & 103.31 \\
\hline $\mathrm{D}$ & 66.69 & 157.05 & 3.22 & 548.86 & 348.56 & 103.41 \\
\hline $\mathrm{E}$ & 69.25 & 155.46 & 3.22 & 548.17 & 349.42 & 104.52 \\
\hline A & 65.08 & 156.05 & 3.38 & 552.41 & 355.02 & 108.26 \\
\hline B & 66.54 & 162.44 & 3.23 & 552.46 & 357.75 & 106.40 \\
\hline $\mathrm{C}$ & 64.66 & 157.78 & 3.33 & 548.55 & 353.40 & 104.65 \\
\hline D & 63.93 & 155.48 & 3.36 & 552.12 & 353.99 & 107.78 \\
\hline $\mathrm{E}$ & 65.95 & 155.38 & 3.86 & 551.09 & 355.92 & 106.57 \\
\hline Average & 66.1 & 157.2 & 3.4 & 547.6 & 352.0 & 105.6 \\
\hline Stdev & 1.6 & 3.8 & 0.2 & 6.0 & 3.4 & 1.6 \\
\hline \%RSD & 2.5 & 2.4 & 6.3 & 1.1 & 1.0 & 1.5 \\
\hline
\end{tabular}

${ }^{1}$ Simulant AN-105 was made using the full Eibling recipe and diluted to $5 \mathrm{M}$ sodium. 
WSRC-STI-2007-00438

SRNL-RPP-2007-00020

Table C - 6. AP-101 Simulant Solution ${ }^{1}$ Precision - Three Runs of Five Filtered Diluted Samples (1:1) in Autosampler.

Three consecutive runs with samples in same position on autosampler

$\begin{aligned} \text { Voltage: } & 40-\mathrm{kV} \quad \text { Current: } 1.2-\mathrm{mA} \\ \text { Atmosphere: } & \mathrm{He}(99.99 \%) \\ \text { Instrument Film: } & \text { Ultralene }-4-\mu \mathrm{m} \text { (film was not replaced) } \\ \text { Cell: } & 31-\mathrm{mm} \text { double open end } \\ \text { Sample film } & \text { Ultralene }-4-\mu \mathrm{m} \\ \text { Cover film: } & \text { Micro-porous Teflon }(0.2-\mu \mathrm{m} \text { pores }) \\ \text { Analysis Time: } & 200 \text {-sec on peak; } 100-\mathrm{sec} \text { on background } \\ \text { Volume: } & 4-\mathrm{mL} \text { filtered supernate }+4-\mathrm{mL} \text { DI water }\end{aligned}$

Background Subtracted Intensities

\begin{tabular}{|c|c|c|c|c|c|c|c|c|}
\hline & $\begin{array}{l}\mathrm{Na} \\
\mathrm{cps}\end{array}$ & $\begin{array}{c}\text { Al } \\
\text { cps }\end{array}$ & $\begin{array}{c}\mathbf{P} \\
\text { cps }\end{array}$ & $\begin{array}{c}\mathrm{Cl} \\
\mathrm{Cps}\end{array}$ & $\begin{array}{c}\mathbf{K} \\
\text { cps }\end{array}$ & $\begin{array}{l}\mathrm{Cr} \\
\mathrm{cps}\end{array}$ & $\begin{array}{l}\text { Mo } \\
\text { cps }\end{array}$ & $\begin{array}{c}\mathrm{S} \\
\text { cps }\end{array}$ \\
\hline Water Blank & 0.00 & 7.32 & 0.00 & 3.91 & 60.84 & 6.74 & 0.00 & 2.34 \\
\hline A & 56.21 & 90.36 & 12.28 & 173.88 & 2104.42 & 26.03 & 21.24 & 83.51 \\
\hline B & 58.11 & 91.58 & 12.31 & 176.68 & 2115.30 & 26.65 & 15.25 & 85.01 \\
\hline $\mathrm{C}$ & 58.28 & 94.45 & 12.36 & 174.40 & 2124.12 & 26.25 & 20.50 & 85.63 \\
\hline D & 59.22 & 104.09 & 12.17 & 178.56 & 2129.52 & 26.51 & 19.98 & 93.66 \\
\hline E & 57.65 & 97.66 & 11.64 & 176.01 & 2127.38 & 26.33 & 19.51 & 85.68 \\
\hline A & 53.00 & 98.85 & 11.86 & 175.87 & 2109.87 & 26.51 & 23.37 & 84.57 \\
\hline B & 59.14 & 112.88 & 12.28 & 182.55 & 2121.33 & 26.65 & 17.47 & 85.57 \\
\hline $\mathrm{C}$ & 58.01 & 106.19 & 12.34 & 179.81 & 2129.18 & 26.41 & 18.43 & 85.86 \\
\hline D & 56.65 & 116.64 & 12.04 & 183.32 & 2121.90 & 27.13 & 24.37 & 100.66 \\
\hline E & 57.61 & 109.69 & 11.89 & 182.25 & 2123.97 & 26.28 & 23.11 & 88.07 \\
\hline A & 56.25 & 92.93 & 11.92 & 176.48 & 2142.57 & 26.94 & 20.97 & 84.82 \\
\hline B & 57.92 & 97.78 & 11.81 & 177.12 & 2155.36 & 27.18 & 22.25 & 85.29 \\
\hline $\mathrm{C}$ & 62.95 & 101.79 & 12.46 & 181.44 & 2159.83 & 27.43 & 19.95 & 87.36 \\
\hline D & 57.88 & 99.21 & 12.05 & 178.52 & 2156.70 & 27.69 & 18.67 & 87.92 \\
\hline $\mathrm{E}$ & 60.19 & 101.23 & 12.44 & 179.87 & 2167.90 & 26.90 & 22.70 & 87.51 \\
\hline Average & 57.9 & 101.0 & 12.1 & 178.5 & 2132.6 & 26.7 & 20.5 & 87.4 \\
\hline Stdev & 2.2 & 7.7 & 0.3 & 3.0 & 19.3 & 0.5 & 2.5 & 4.4 \\
\hline \%RSD & 3.7 & 7.7 & 2.1 & 1.7 & 0.9 & 1.8 & 12.0 & 5.0 \\
\hline
\end{tabular}

${ }^{1}$ Simulant AP-101 was made using the Full Eibling recipe 
WSRC-STI-2007-00438

SRNL-RPP-2007-00020

\section{Table C - 7. AP-101 Simulant Solution ${ }^{1}$ Precision - Three Runs of Five Filtered Acidic} Samples in Autosampler.

Three consecutive runs with samples in same position on autosampler.

\begin{tabular}{|c|c|c|c|c|c|c|c|c|}
\hline \multirow{12}{*}{$\begin{array}{r}\text { Voltage: } \\
\text { Atmosphere: } \\
\text { Instrument Film: } \\
\text { Cell: } \\
\text { Sample film } \\
\text { Cover film: } \\
\text { Analysis Time: } \\
\text { Volume: } \\
\\
\end{array}$} & \multirow{2}{*}{\multicolumn{8}{|c|}{ Current: $1.2-\mathrm{mA}$}} \\
\hline & & & & & & & & \\
\hline & \multicolumn{8}{|c|}{ He $(99.99 \%)$} \\
\hline & \multicolumn{8}{|c|}{ Ultralene - 4- $\mu \mathrm{m}$ (film was not replaced) } \\
\hline & \multicolumn{8}{|c|}{ 31-mm double open end } \\
\hline & \multicolumn{8}{|c|}{ Ultralene - 4- $\mu \mathrm{m}$} \\
\hline & \multicolumn{8}{|c|}{ Micro-porous Teflon $(0.2-\mu \mathrm{m}$ pores $)$} \\
\hline & \multicolumn{8}{|c|}{200 -sec on peak; 100 -sec on background } \\
\hline & \multicolumn{8}{|c|}{ 4-mL filtered supernate $+2-\mathrm{mL}$ DI water $+2-\mathrm{mL} \mathrm{HNO}_{3}$} \\
\hline & \multicolumn{8}{|c|}{ Background Subtracted Intensities } \\
\hline & $\mathrm{Na}$ & Al & $\mathbf{P}$ & $\mathbf{C l}$ & $\mathbf{K}$ & $\overline{\mathrm{Cr}}$ & Mo & $\mathbf{S}$ \\
\hline & cps & cps & cps & cps & cps & cps & cps & cps \\
\hline Water Blank & 0.00 & 3.83 & 0.20 & 5.44 & 62.21 & 7.54 & 0.00 & 20.34 \\
\hline A & 48.42 & 85.89 & 11.20 & 162.08 & 1971.90 & 25.60 & 20.40 & 77.99 \\
\hline $\mathrm{B}$ & 52.82 & 91.99 & 11.58 & 166.24 & 1993.70 & 25.73 & 18.79 & 78.74 \\
\hline $\mathrm{C}$ & 54.23 & 90.91 & 11.50 & 165.12 & 2000.74 & 25.62 & 20.70 & 80.14 \\
\hline D & 51.71 & 90.82 & 11.48 & 167.27 & 1993.44 & 25.13 & 21.99 & 81.11 \\
\hline E & 53.30 & 91.38 & 11.36 & 166.72 & 1990.64 & 25.78 & 12.89 & 80.16 \\
\hline A & 52.28 & 88.32 & 11.51 & 161.67 & 1980.79 & 24.82 & 17.38 & 78.78 \\
\hline B & 52.83 & 88.19 & 10.83 & 163.24 & 1974.78 & 26.10 & 15.53 & 77.98 \\
\hline $\mathrm{C}$ & 53.95 & 87.83 & 11.39 & 164.30 & 1982.02 & 24.82 & 23.10 & 79.27 \\
\hline $\mathrm{D}$ & 51.43 & 88.73 & 11.08 & 164.61 & 1976.26 & 25.36 & 23.47 & 80.24 \\
\hline E & 51.58 & 90.49 & 11.15 & 163.92 & 1982.03 & 25.12 & 20.12 & 79.80 \\
\hline A & 50.86 & 87.94 & 11.48 & 163.94 & 1991.78 & 25.11 & 21.38 & 78.80 \\
\hline B & 50.82 & 87.55 & 11.35 & 163.48 & 1989.87 & 25.75 & 22.77 & 79.52 \\
\hline $\mathrm{C}$ & 50.64 & 87.83 & 11.64 & 164.05 & 1997.58 & 25.50 & 28.53 & 79.15 \\
\hline D & 51.33 & 87.11 & 11.36 & 164.41 & 1993.81 & 25.28 & 15.01 & 79.38 \\
\hline $\mathrm{E}$ & 52.47 & 90.45 & 11.20 & 165.46 & 2000.10 & 25.12 & 23.78 & 79.34 \\
\hline Average & 51.9 & 89.0 & 11.3 & 164.4 & 1988.0 & 25.4 & 20.4 & 79.4 \\
\hline Stdev & 1.5 & 1.8 & 0.2 & 1.6 & 9.3 & 0.4 & 4.0 & 0.9 \\
\hline \% RSD & 2.8 & 2.0 & 1.9 & 1.0 & 0.5 & 1.5 & 19.6 & 1.1 \\
\hline
\end{tabular}

${ }^{1}$ Simulant AP-101 was made using the full Eibling recipe. 
WSRC-STI-2007-00438

SRNL-RPP-2007-00020

\subsection{Appendix D: Representative Calibration Curves}

\section{Aluminum Calibration Curve}

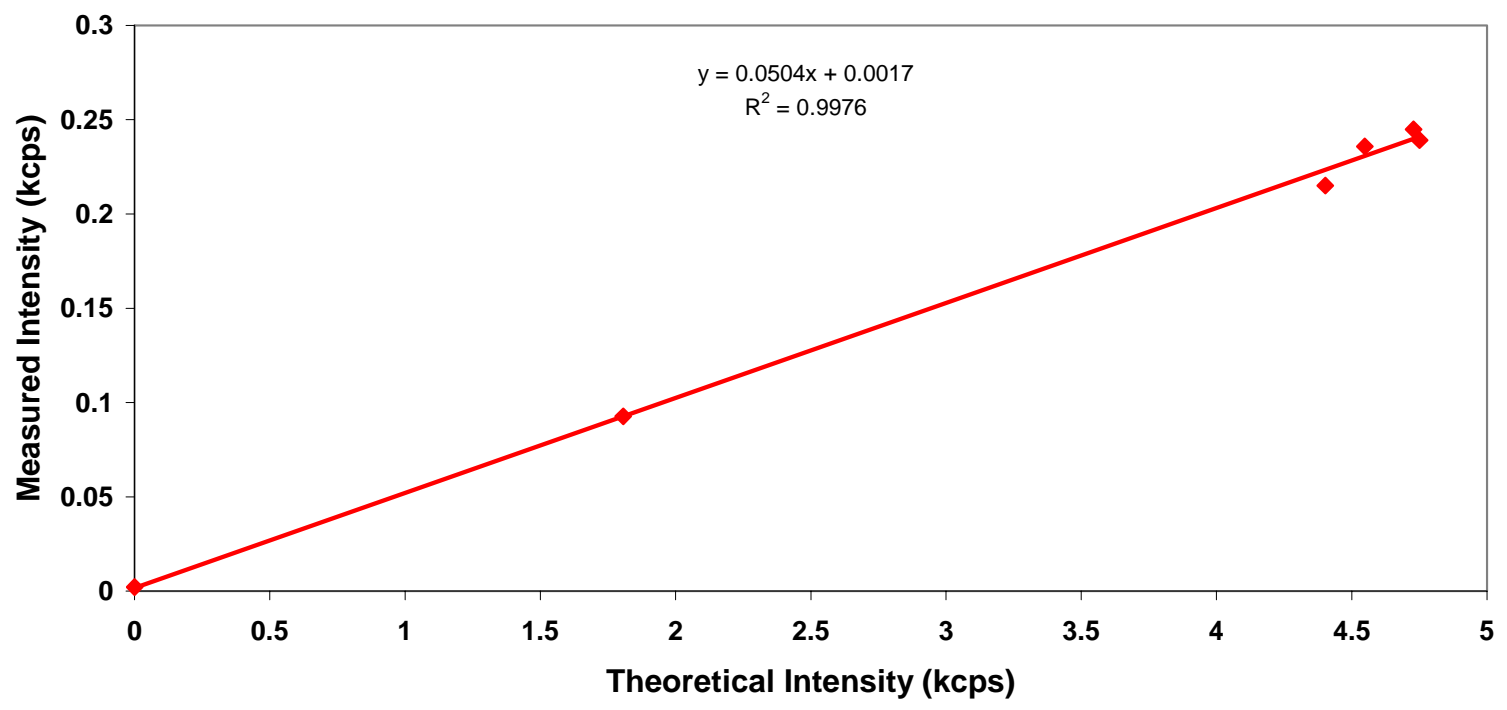

Figure D - 1. Aluminum calibration curve using all five High Purity standards.

\section{Calcium Calibration Curve}

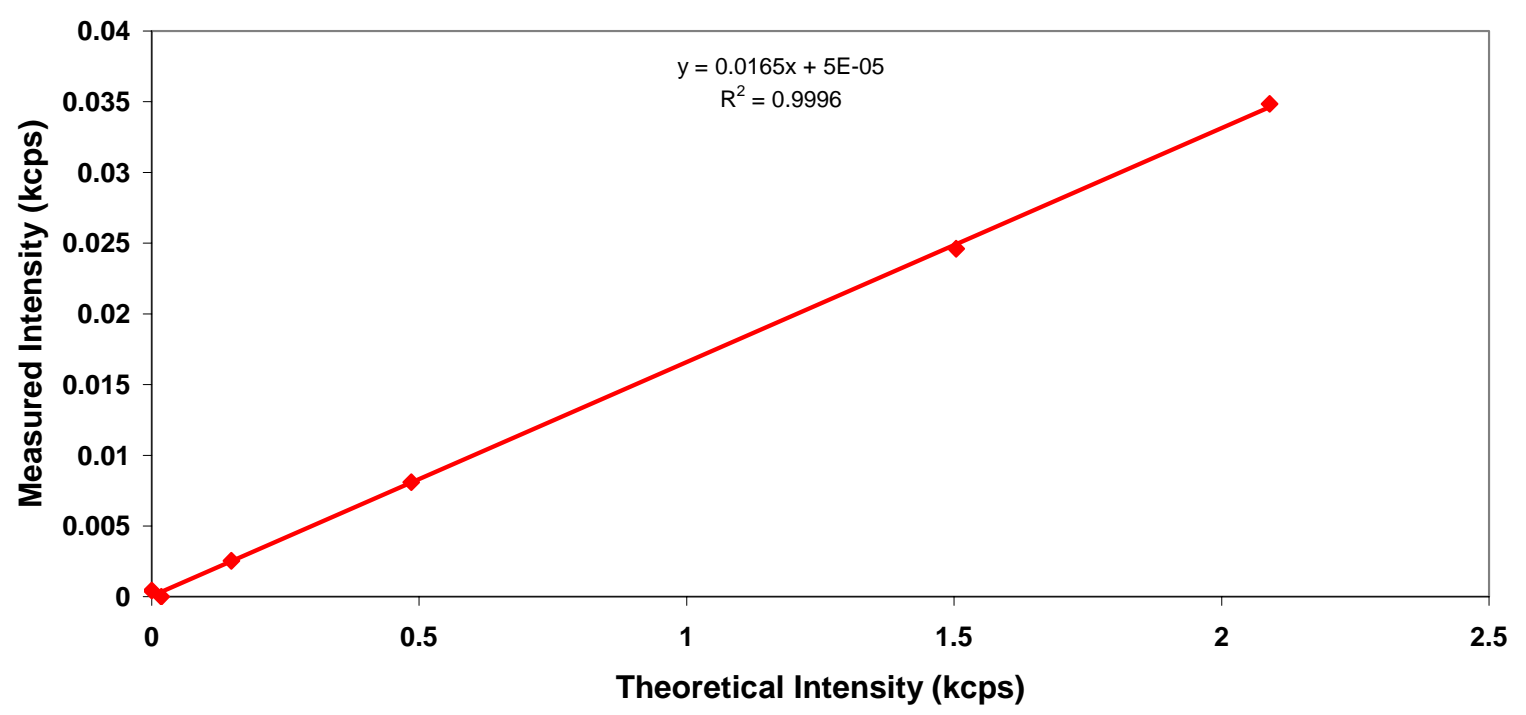

Figure D - 2. Calcium calibration curve using all five High Purity standards. 
WSRC-STI-2007-00438

SRNL-RPP-2007-00020

\section{Chlorine Calibration Curve}

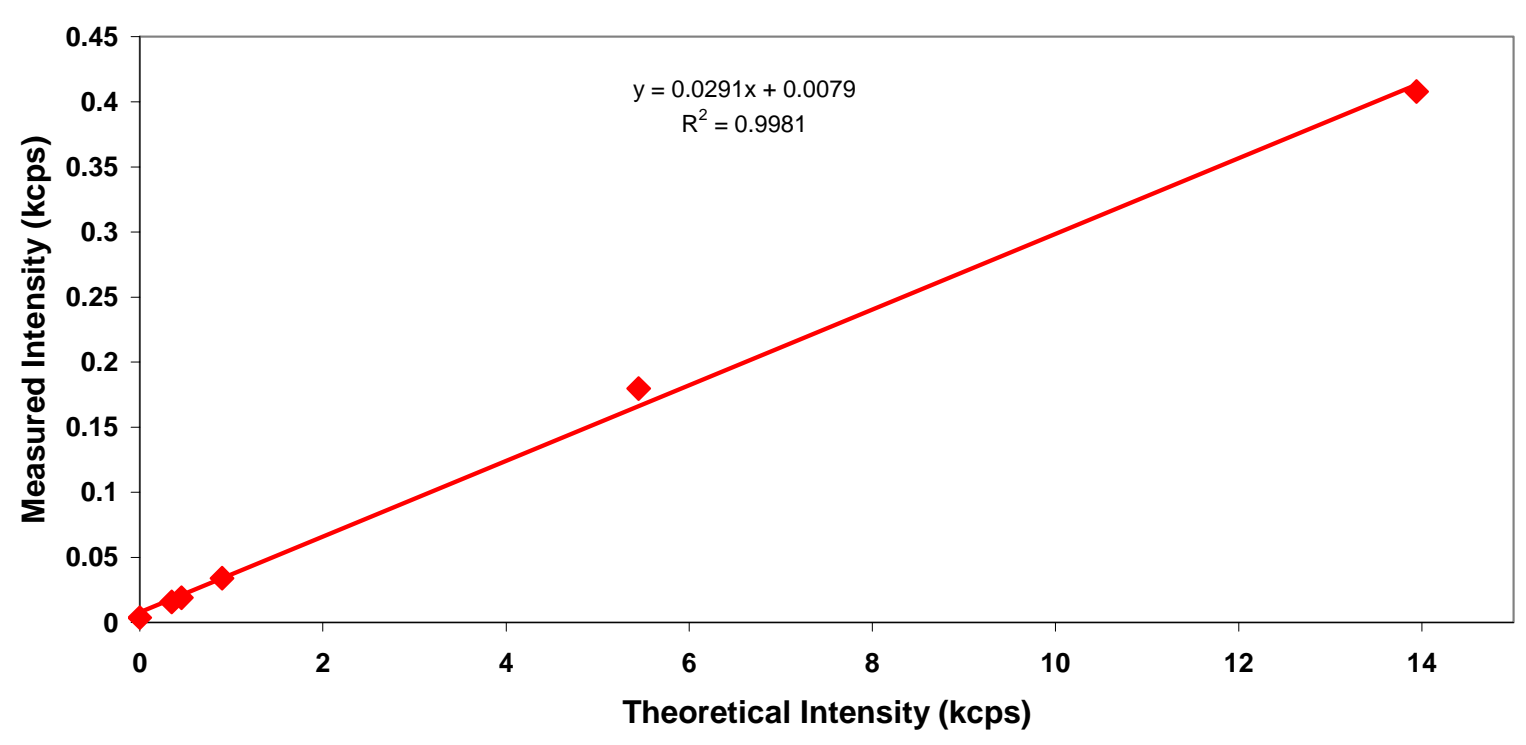

Figure D - 3. Chlorine calibration curve using all five High Purity standards.

\section{Chromium Calibration Curve}

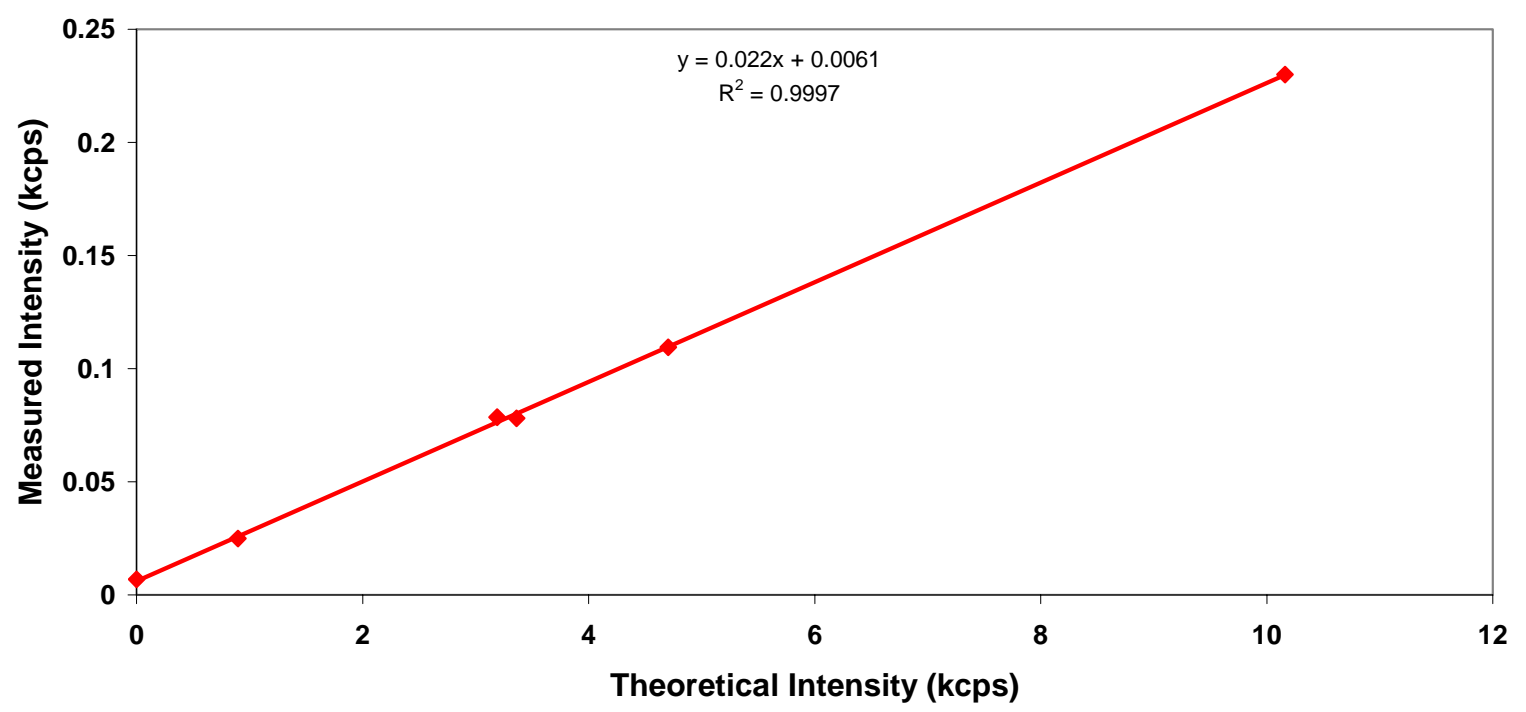

Figure D - 4. Chromium calibration curve using all five High Purity standards. 
WSRC-STI-2007-00438

SRNL-RPP-2007-00020

Molybdenum Calibration Curve

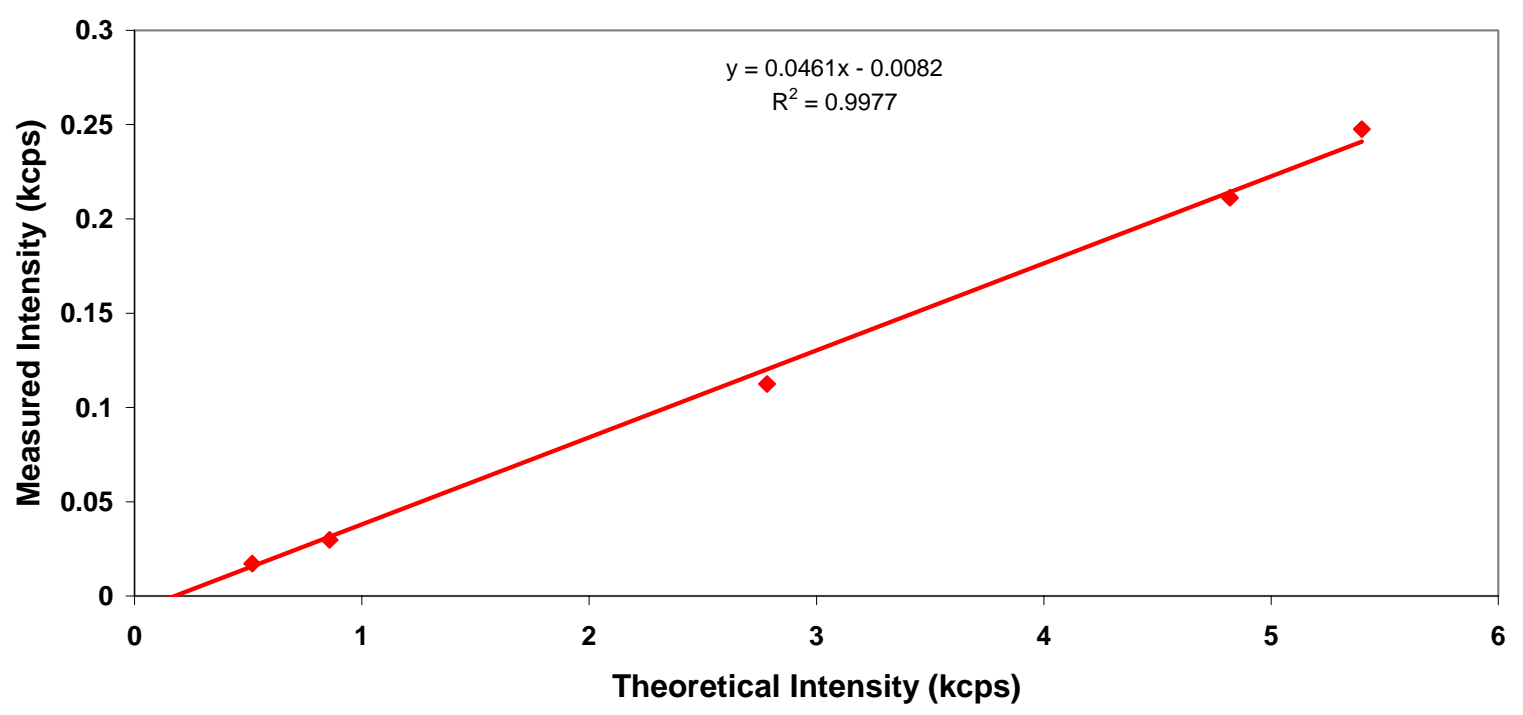

Figure D - 5. Molybdenum calibration curve using all five High Purity standards.

Nickel Calibration Curve

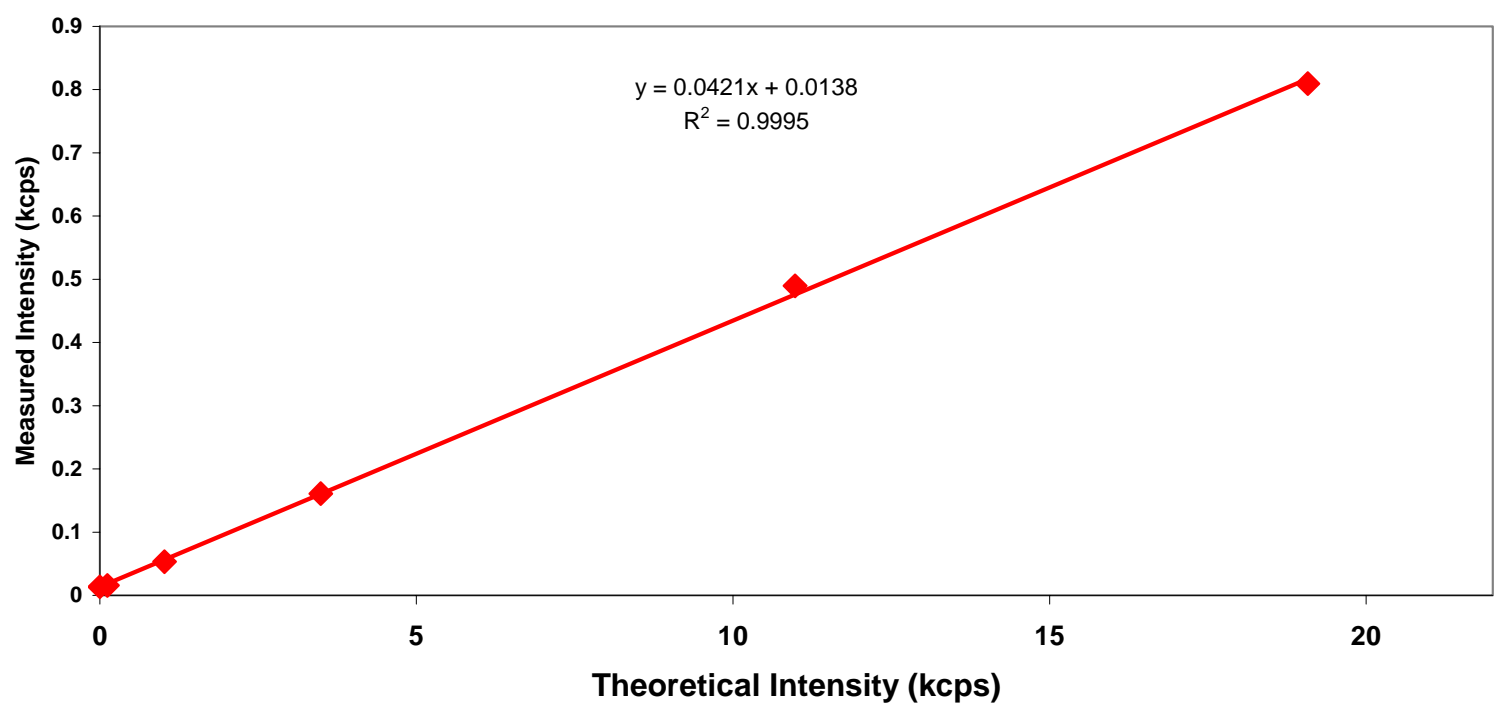

Figure D - 6. Nickel calibration curve using all five High Purity standards. 
WSRC-STI-2007-00438

SRNL-RPP-2007-00020

Phosphorus Calibration Curve

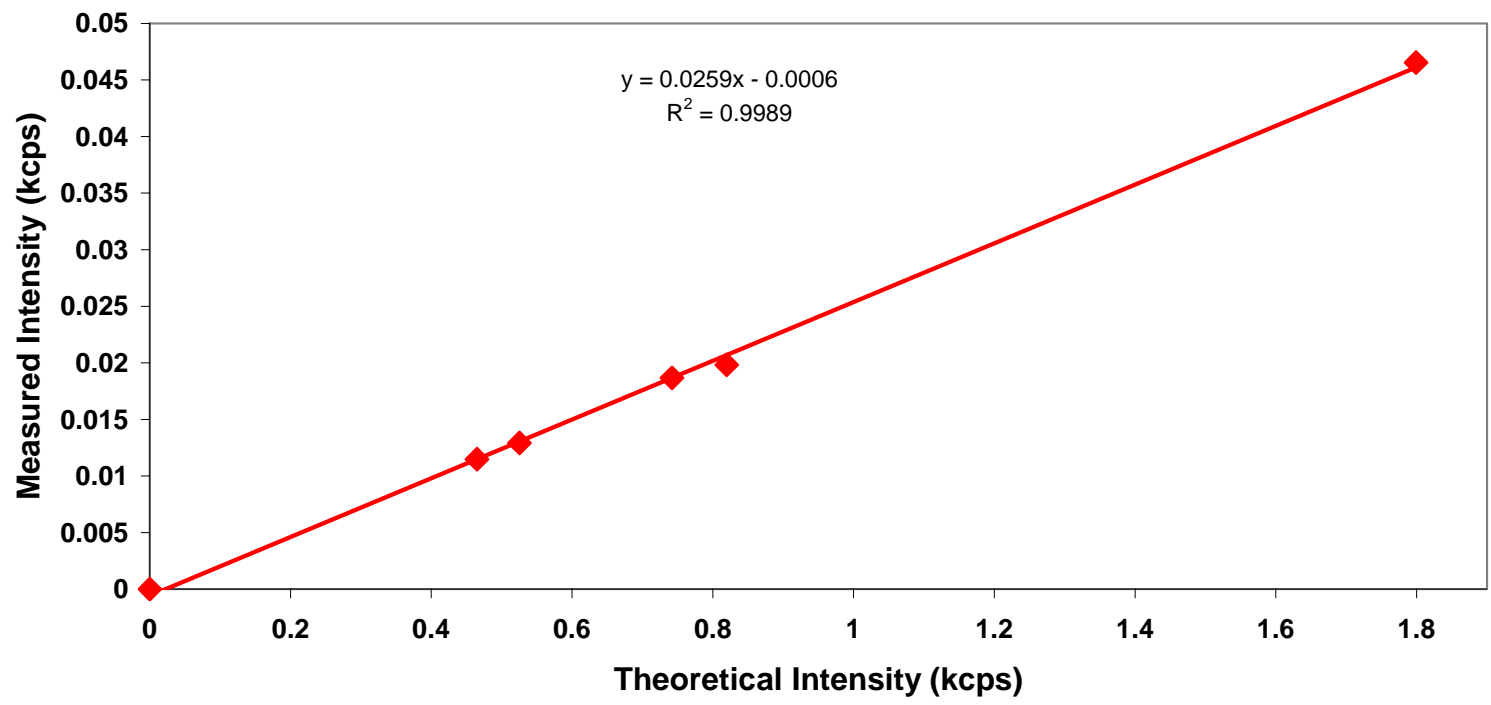

Figure D - 7. Phosphorus calibration curve using all five High Purity standards.

\section{Potassium Calibration Curve}

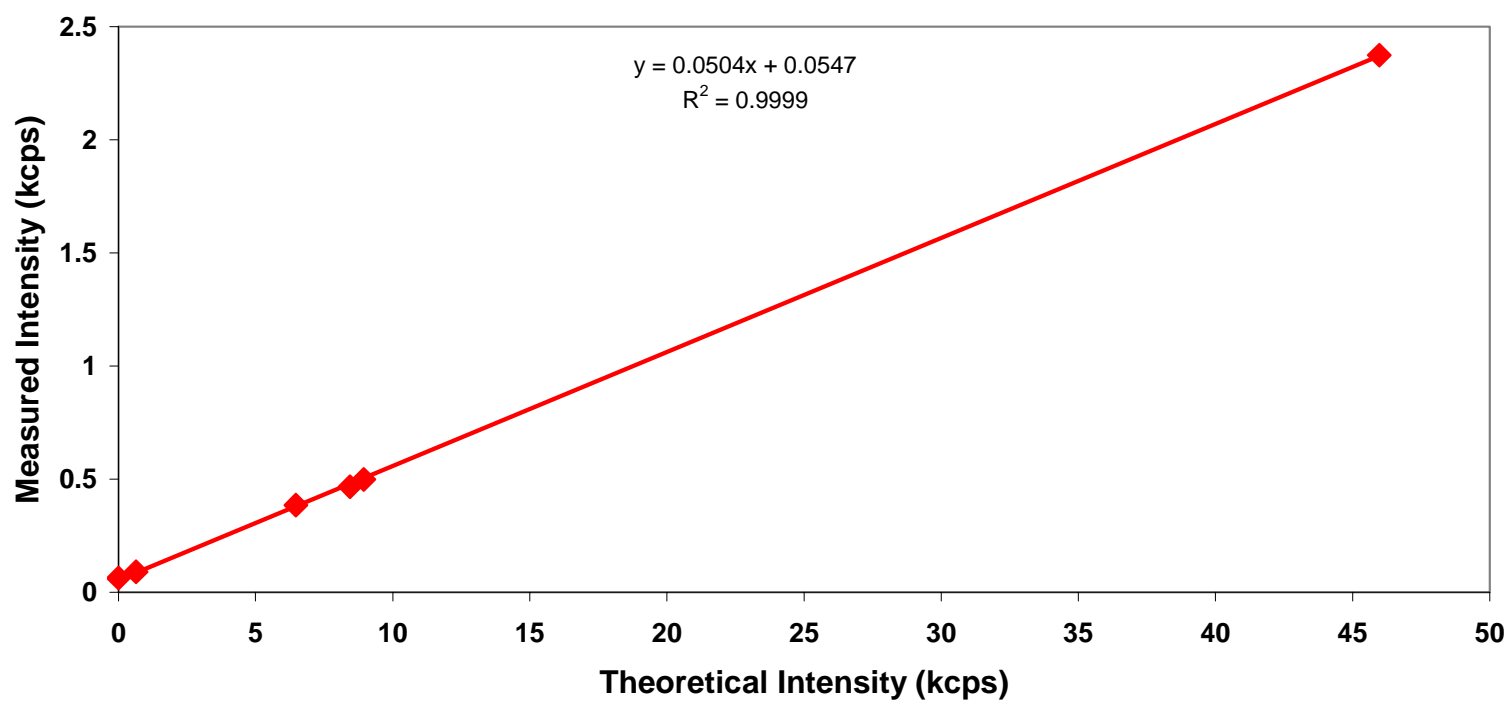

Figure D - 8. Potassium calibration curve using all five High Purity standards. 
WSRC-STI-2007-00438

SRNL-RPP-2007-00020

\section{Sodium Calibration Curve}

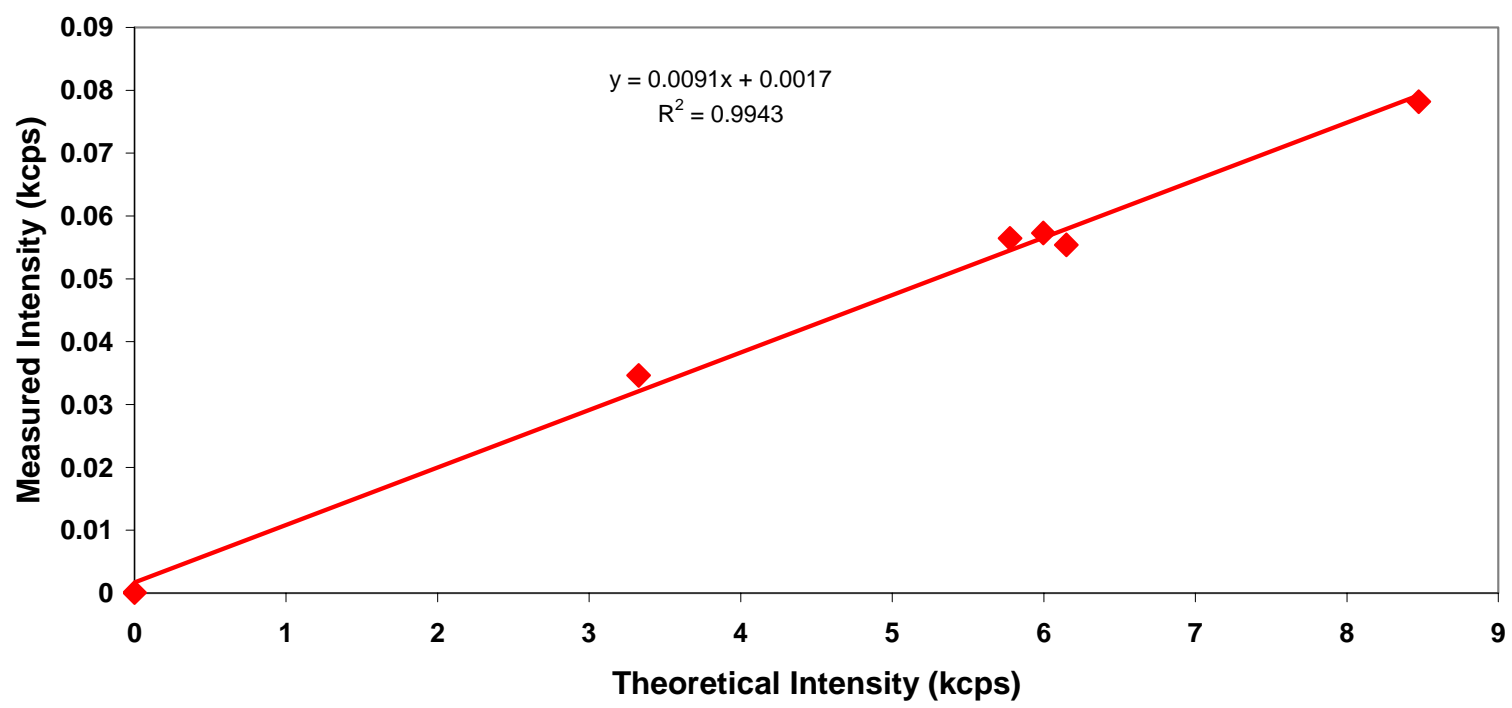

Figure D - 9. Sodium calibration curve using all five High Purity standards.

\section{Sulfur Calibration Curve}

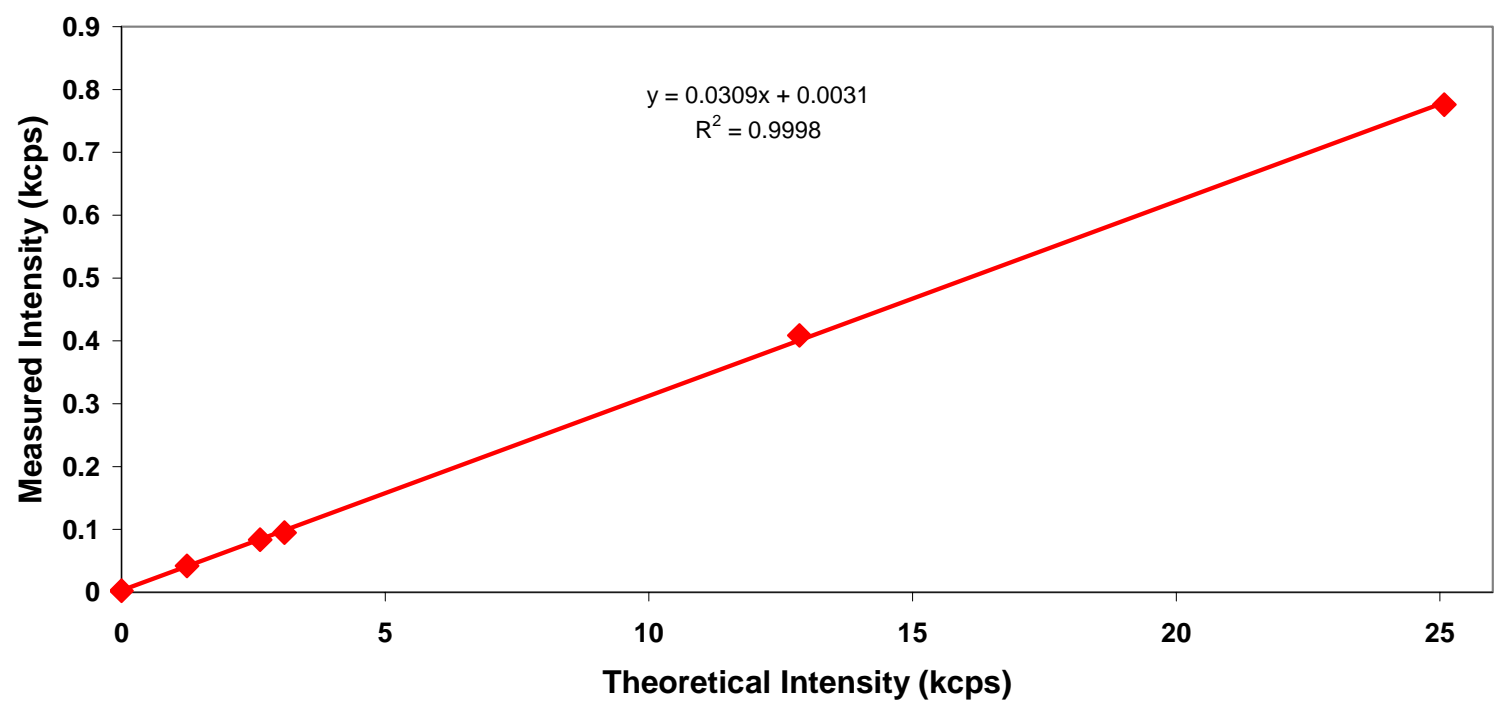

Figure D - 10. Sulfur calibration curve using all five High Purity standards. 
WSRC-STI-2007-00438

SRNL-RPP-2007-00020

\subsection{Appendix E: WD-XRF Results}


WSRC-STI-2007-00438

SRNL-RPP-2007-00020

Table E - 1. WD-XRF Analysis of RPP Acidified Simulants.

Envelope A (AN-105 \& AP-101 simulant), Envelope C (AN-107 simulant), and Envelope B/D (AZ-101 simulant) Analysis The instrument was calibrated using five High Purity standards for each run.

Voltage: $40-\mathrm{k} V$

Atmosphere: $\mathrm{He}(99.99 \%)$

Instrument Film: Ultralene - 4- $\mu \mathrm{m}$ (film was replaced for calibration and analysis)

Cell: $\quad 31-\mathrm{mm}$ double open end

Sample film Ultralene - 4- $\mu \mathrm{m}$

Cover film: Micro-porous Teflon $(0.2-\mu \mathrm{m}$ pores $)$

Analysis Time: $\quad 200$-sec on peak; 100 -sec on backgroun

Volume: $\quad 4-\mathrm{mL}$ filtered supernate +2 -mL DI water $+2-\mathrm{mL} \mathrm{HNO}_{3}$

\begin{tabular}{|c|c|c|c|c|c|c|c|c|c|c|}
\hline & $\begin{array}{c}\mathrm{Al} \\
\mu \mathrm{g} / \mathrm{mL}\end{array}$ & $\begin{array}{c}\mathrm{Ca} \\
\mu \mathrm{g} / \mathrm{mL}\end{array}$ & $\begin{array}{c}\mathrm{Cr} \\
\mu \mathrm{g} / \mathrm{mL}\end{array}$ & $\begin{array}{c}\begin{array}{c}\mathrm{Mo} \\
\mu \mathrm{g} / \mathrm{mL}\end{array} \\
\end{array}$ & $\begin{array}{c}\mathbf{N i} \\
\mu \mathrm{g} / \mathrm{mL}\end{array}$ & $\begin{array}{c}\mathrm{K} \\
\mu \mathrm{g} / \mathrm{mL}\end{array}$ & $\begin{array}{c}\mathrm{Na} \\
\mu \mathrm{g} / \mathrm{mL}\end{array}$ & $\begin{array}{c}\mathrm{SO}_{4} \\
\mu \mathrm{g} / \mathrm{mL}\end{array}$ & $\begin{array}{c}\mathrm{PO}_{4} \\
\mu \mathrm{g} / \mathrm{mL}\end{array}$ & $\begin{array}{c}\mathrm{Cl} \\
\mu \mathrm{g} / \mathrm{mL}\end{array}$ \\
\hline AN-105 & 12212 & $\begin{array}{l}<10 \\
\end{array}$ & 710 & 42 & $\begin{array}{l}<2 \\
<2\end{array}$ & $\begin{array}{l}4070 \\
\end{array}$ & 148748 & 557 & 362 & 5264 \\
\hline $\mathrm{AN}-105$ & 11100 & $<10$ & 678 & 38 & $<2$ & 3824 & 124132 & 389 & 368 & 4934 \\
\hline AN-105 & 11448 & $<10$ & 678 & 42 & $<2$ & 3866 & 128410 & 330 & 374 & 4858 \\
\hline AN-105 & 11432 & $<10$ & 684 & 40 & $<2$ & 3908 & 135206 & 318 & 368 & 4978 \\
\hline AN-105 & 11020 & $<10$ & 682 & 42 & $<2$ & 3884 & 125158 & 389 & 356 & 4948 \\
\hline AN-105 & 11196 & $<10$ & 692 & 38 & $<2$ & 3860 & 126640 & 383 & 356 & 4978 \\
\hline AN-105 & 11222 & $<10$ & 674 & 42 & $<2$ & 3842 & 129978 & 372 & 319 & 4988 \\
\hline AN- 105 & 11542 & $<10$ & 690 & 42 & $<2$ & 3868 & 123876 & 360 & 374 & 4922 \\
\hline AN-105 & 11514 & $<10$ & 678 & 42 & $<2$ & 3824 & 125558 & 395 & 356 & 5000 \\
\hline AN-105 & 11216 & $<10$ & 678 & 44 & $<2$ & 3818 & 125028 & 395 & 331 & 4852 \\
\hline AN- 105 & 11378 & $<10$ & 680 & 42 & $<2$ & 3942 & 129452 & 479 & 392 & 4992 \\
\hline Average & 11390 & & 684 & 41 & & 3876 & 129273 & 389 & 356 & 4972 \\
\hline STDEV & 339 & & 11 & 2 & & 74 & 7652 & 65 & 18 & 115 \\
\hline \%RSD & 3 & & 2 & 5 & & 2 & 6 & 17 & 5 & 2 \\
\hline AP-101 & 7384 & $<10$ & 160 & 12 & $<2$ & 28204 & 131148 & 3835 & 1318 & 1592 \\
\hline AP-101 & 6968 & $<10$ & 158 & 14 & $<2$ & 27878 & 118704 & 3637 & 1288 & 1570 \\
\hline AP-101 & 6968 & $<10$ & 154 & 14 & $<2$ & 27734 & 121234 & 3541 & 1282 & 1526 \\
\hline AP-101 & 6834 & $<10$ & 152 & 14 & $<2$ & 27682 & 116576 & 3643 & 1245 & 1532 \\
\hline AP-101 & 6988 & $<10$ & 154 & 12 & $<2$ & 28140 & 122696 & 3667 & 1294 & 1588 \\
\hline AP-101 & 7018 & $<10$ & 156 & 14 & $<2$ & 28158 & 122508 & 3661 & 1263 & 1586 \\
\hline AP-101 & 7186 & $<10$ & 148 & 12 & $<2$ & 28108 & 123634 & 3649 & 1226 & 1568 \\
\hline AP-101 & 7208 & $<10$ & 158 & 16 & $<2$ & 28630 & 124344 & 3757 & 1355 & 1588 \\
\hline AP-101 & 6842 & $<10$ & 156 & 16 & $<2$ & 28094 & 117380 & 3709 & 1306 & 1564 \\
\hline AP-101 & 7200 & $<10$ & 158 & 16 & $<2$ & 28228 & 127208 & 3757 & 1331 & 1562 \\
\hline AP-101 & 7130 & $<10$ & 148 & 12 & $<2$ & 28382 & 125608 & 3739 & 1368 & 1596 \\
\hline Average & 7060 & & 155 & 14 & & 28086 & 122543 & 3686 & 1291 & 1568 \\
\hline STDEV & 178 & & 4 & 2 & & 273 & 4459 & 82 & 39 & 23 \\
\hline$\%$ RSD & 3 & & 2 & 12 & & 1 & 4 & 2 & 3 & 1 \\
\hline AN-107 & 340 & 154 & $<5$ & 24 & 294 & 1056 & 141956 & 4830 & 859 & 1278 \\
\hline AN-107 & 384 & 160 & $<5$ & 20 & 308 & 1210 & 160290 & 5087 & 914 & 1354 \\
\hline AN- 107 & 250 & 148 & $<5$ & 18 & 306 & 1178 & 142918 & 4872 & 908 & 1348 \\
\hline AN-107 & 288 & 144 & $<5$ & 22 & 304 & 1218 & 143358 & 4937 & 987 & 1356 \\
\hline AN-107 & 218 & 138 & $<5$ & 22 & 304 & 1172 & 144806 & 4997 & 957 & 1362 \\
\hline AN-107 & 172 & 142 & $<5$ & 22 & 308 & 1216 & 143372 & 4967 & 938 & 1362 \\
\hline AN- 107 & 370 & 152 & $<5$ & 22 & 308 & 1172 & 143570 & 4967 & 914 & 1372 \\
\hline AN-107 & 252 & 150 & $<5$ & 18 & 304 & 1192 & 138156 & 5003 & 987 & 1354 \\
\hline AN-107 & 268 & 148 & $<5$ & 22 & 306 & 1186 & 146320 & 4973 & 963 & 1370 \\
\hline AN-107 & 270 & 132 & $<5$ & 20 & 310 & 1158 & 146298 & 5021 & 920 & 1342 \\
\hline AN-107 & 228 & 154 & $<5$ & 22 & 306 & 1186 & 149464 & 5111 & 963 & 1370 \\
\hline Average & 281 & 147 & & 21 & 305 & 1176 & 145104 & 4966 & 935 & 1350 \\
\hline STDEV & 67 & 8 & & 2 & 4 & 47 & 5821 & 73 & 40 & 27 \\
\hline$\%$ RSD & 24 & 6 & & 9 & 1 & 4 & 4 & 1 & 4 & 2 \\
\hline AZ-101 & $<80$ & $<10$ & 140 & 24 & $<2$ & 766 & 11158 & 875 & $<30$ & 262 \\
\hline AZ-101 & $<80$ & $<10$ & 154 & 26 & $<2$ & 968 & 9434 & 917 & $<30$ & 296 \\
\hline AZ-101 & $<80$ & $<10$ & 162 & 24 & $<2$ & 910 & 10088 & 791 & $<30$ & 268 \\
\hline AZ-101 & $<80$ & $<10$ & 150 & 26 & $<2$ & 918 & 9872 & 809 & $<30$ & 284 \\
\hline AZ-101 & $<80$ & $<10$ & 142 & 26 & $<2$ & 918 & 8870 & 749 & $<30$ & 270 \\
\hline AZ-101 & $<80$ & $<10$ & 150 & 26 & $<2$ & 954 & 10726 & 809 & $<30$ & 300 \\
\hline AZ-101 & $<80$ & $<10$ & 150 & 24 & $<2$ & 920 & 8754 & 827 & $<30$ & 308 \\
\hline AZ-101 & $<80$ & $<10$ & 148 & 26 & $<2$ & 908 & 10044 & 839 & $<30$ & 284 \\
\hline AZ-101 & $<80$ & $<10$ & 152 & 26 & $<2$ & 904 & 9490 & 827 & $<30$ & 274 \\
\hline AZ-101 & $<80$ & $<10$ & 150 & 24 & $<2$ & 858 & 9382 & 851 & $<30$ & 264 \\
\hline AZ-101 & $<80$ & $<10$ & 148 & 26 & $<2$ & 932 & 9368 & 845 & $<30$ & 306 \\
\hline Average & & & 150 & 25 & & 902 & 9782 & 829 & & 281 \\
\hline STDEV & & & 6 & 1 & & 56 & 761 & 46 & & 16 \\
\hline \%RSD & & & 4 & 4 & & 6 & 8 & 6 & & 6 \\
\hline Blank & 66 & 5 & 0 & 0 & 1 & 24 & 0 & 29 & 1 & 0 \\
\hline Blank & 90 & 7 & 6 & 0 & 0 & 41 & 0 & 27 & 3 & 0 \\
\hline Blank & 87 & 3 & 1 & 0 & 0 & 59 & 2352 & 2 & 9 & 0 \\
\hline Blank & 2 & 0 & 0 & 2 & 0 & 69 & 0 & 0 & 8 & 0 \\
\hline Blank & 0 & 0 & 0 & 1 & 0 & 73 & 0 & 0 & 12 & 0 \\
\hline Blank & 45 & 6 & 0 & 0 & 1 & 53 & 0 & 0 & 4 & 0 \\
\hline Blank & 18 & 6 & 2 & 0 & 0 & 61 & 0 & 3 & 12 & 0 \\
\hline Blank & 1 & 4 & 0 & 0 & 0 & 74 & 0 & 0 & 8 & 0 \\
\hline Blank & 11 & 2 & 2 & 1 & 1 & 55 & 0 & 7 & 4 & 0 \\
\hline Blank & 83 & 7 & 0 & 0 & 1 & 74 & 0 & 11 & 7 & 0 \\
\hline
\end{tabular}


WSRC-STI-2007-00438

SRNL-RPP-2007-00020

Table E - 2. WD-XRF Analysis of RPP Basic Simulants.

Envelope A (AN-105 \& AP-101 simulant), Envelope C (AN-107 simulant), and Envelope B/D (AZ-101 simulant) Analysis The instrument was calibrated using five High Purity standards for each run.

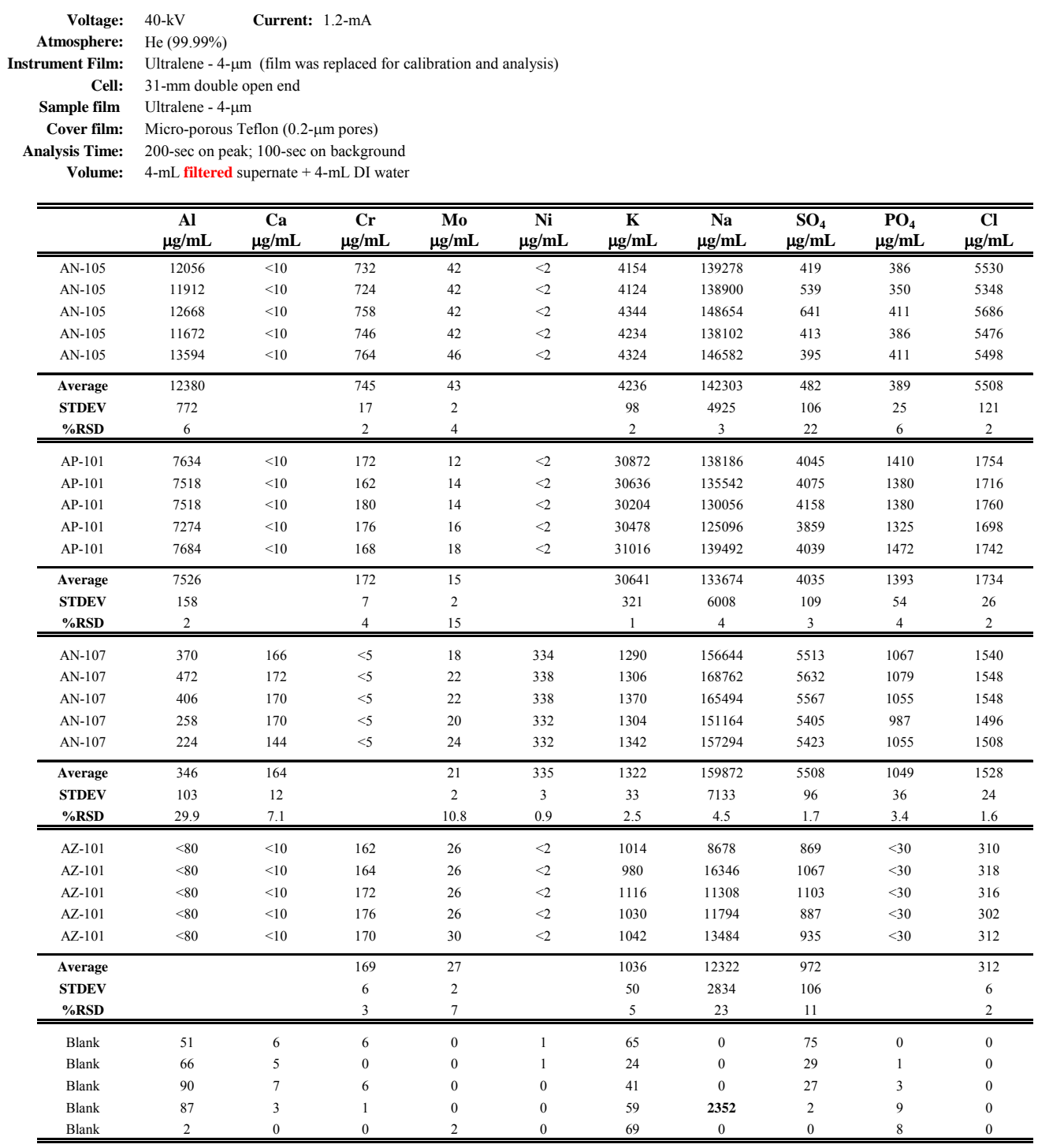


WSRC-STI-2007-00438

SRNL-RPP-2007-00020

Table E - 3. WD-XRF Analysis of RPP Acidified Simulants using Drift Correction.

Envelope A (AN-105 \& AP-101 simulant), Envelope C (AN-107 simulant), and Envelope B/D (AZ-101 simulant) Analysis The instrument was calibrated one time using four High Purity standards ${ }^{1}$ and then daily using a High Purity standard as a drift monitor

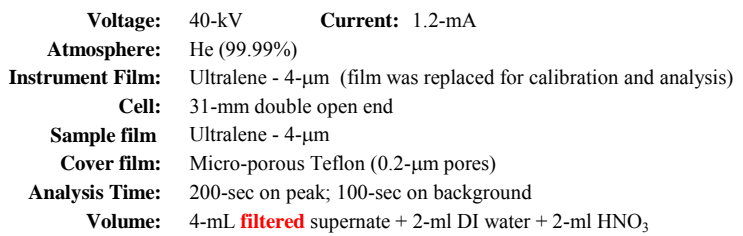

\begin{tabular}{|c|c|c|c|c|c|c|c|c|c|c|}
\hline & $\begin{array}{c}\text { Al } \\
\mu \mathrm{g} / \mathrm{mL}\end{array}$ & $\begin{array}{c}\text { Ca } \\
\mu \mathrm{g} / \mathrm{mL}\end{array}$ & $\begin{array}{c}\mathrm{Cr} \\
\mu \mathrm{g} / \mathrm{mL}\end{array}$ & $\begin{array}{c}\text { Mo } \\
\mu \mathrm{g} / \mathrm{mL}\end{array}$ & $\begin{array}{c}\mathrm{Ni} \\
\mu \mathrm{g} / \mathrm{mL}\end{array}$ & $\begin{array}{c}\mathbf{K} \\
\mu \mathrm{g} / \mathrm{mL}\end{array}$ & $\begin{array}{c}\mathrm{Na} \\
\mu \mathrm{g} / \mathrm{mL}\end{array}$ & $\begin{array}{c}\mathrm{SO}_{4} \\
\mu \mathrm{g} / \mathrm{mL}\end{array}$ & $\begin{array}{c}\mathrm{PO}_{4} \\
\mu \mathrm{g} / \mathrm{mL}\end{array}$ & $\begin{array}{c}\text { Cl } \\
\mu \mathrm{g} / \mathrm{mL}\end{array}$ \\
\hline AN-105 & 12780 & $<10$ & 676 & 40 & $<2$ & 3936 & 135294 & 425 & 331 & 5060 \\
\hline AN-105 & 11704 & $<10$ & 676 & 38 & $<2$ & 3970 & 137024 & 461 & 258 & 5376 \\
\hline AN-105 & 11774 & $<10$ & 704 & 40 & $<2$ & 3944 & 134608 & 443 & 337 & 5546 \\
\hline AN- 105 & 12140 & $<10$ & 704 & 38 & $<2$ & 4016 & 144198 & 467 & 307 & 5464 \\
\hline AN-105 & 11678 & $<10$ & 688 & 42 & $<2$ & 3952 & 134026 & 461 & 300 & 5366 \\
\hline Average & 12015 & & 690 & 40 & & 3964 & 137030 & 452 & 307 & 5362 \\
\hline STDEV & 466 & & 14 & 2 & & 32 & 4162 & 17 & 32 & 184 \\
\hline$\%$ RSD & 4 & & 2 & 4 & & 1 & 3 & 4 & 10 & 3 \\
\hline AP-101 & 7372 & $<10$ & 152 & 12 & $<2$ & 28612 & 128112 & 3721 & 1282 & 1594 \\
\hline AP-101 & 7704 & $<10$ & 156 & 12 & $<2$ & 28974 & 135590 & 3835 & 1380 & 1752 \\
\hline AP-101 & 7198 & $<10$ & 158 & 14 & $<2$ & 28024 & 120392 & 3781 & 1318 & 1724 \\
\hline AP-101 & 7710 & $<10$ & 158 & 14 & $<2$ & 29192 & 138208 & 3925 & 1417 & 1750 \\
\hline AP-101 & 7384 & $<10$ & 162 & 14 & $<2$ & 28460 & 127822 & 3829 & 1300 & 1724 \\
\hline Average & 7474 & & 157 & 13 & & 28652 & 130025 & 3818 & 1339 & 1709 \\
\hline STDEV & 225 & & 4 & 1 & & 455 & 7058 & 75 & 57 & 66 \\
\hline \%RSD & 3 & & 2 & 8 & & 2 & 5 & 2 & 4 & 4 \\
\hline AN- 107 & 374 & 158 & $<5$ & 22 & 308 & 1200 & 146588 & 4997 & 920 & 1386 \\
\hline AN-107 & 474 & 170 & $<5$ & 16 & 312 & 1198 & 157870 & 5207 & 987 & 1490 \\
\hline AN-107 & 404 & 142 & $<5$ & 20 & 306 & 1192 & 145062 & 3236 & 944 & 1516 \\
\hline AN-107 & 398 & 146 & $<5$ & 18 & 298 & 1212 & 159768 & 5249 & 1006 & 1496 \\
\hline AN-107 & 418 & 160 & $<5$ & 20 & 310 & 1184 & 148280 & 5081 & 920 & 1474 \\
\hline Average & 414 & 155 & & 19 & 307 & 1197 & 151514 & 4754 & 955 & 1472 \\
\hline STDEV & 37 & 11 & & 2 & 5 & 10 & 6799 & 855 & 39 & 51 \\
\hline$\%$ RSD & 9 & 7 & & 12 & 2 & 1 & 4 & 18 & 4 & 3 \\
\hline AZ-101 & $<80$ & $<10$ & 150 & 24 & $<2$ & 922 & 12114 & 875 & $<30$ & 280 \\
\hline AZ-101 & $<80$ & $<10$ & 154 & 24 & $<2$ & 910 & 12590 & 893 & $<30$ & 326 \\
\hline AZ-101 & $<80$ & $<10$ & 158 & 24 & $<2$ & 876 & 12092 & 917 & $<30$ & 332 \\
\hline AZ-101 & $<80$ & $<10$ & 164 & 24 & $<2$ & 952 & 14848 & 887 & $<30$ & 308 \\
\hline AZ-101 & $<80$ & $<10$ & 158 & 24 & $<2$ & 896 & 14300 & 929 & $<30$ & 324 \\
\hline Average & & & 157 & 24 & & 911 & 13189 & 900 & & 314 \\
\hline STDEV & & & 5 & 0 & & 29 & 1295 & 22 & & 21 \\
\hline$\%$ RSD & & & 3 & 0 & & 3 & 10 & 2 & & 7 \\
\hline Standard $\mathrm{A}^{3}$ & 9316 & 512 & 261 & 4 & 392 & 259 & 39963 & 938 & 2573 & 39 \\
\hline Standard $\mathrm{A}^{3}$ & 9692 & 538 & 264 & 4 & 392 & 259 & 43063 & 977 & 2631 & 47 \\
\hline Standard $\mathrm{A}^{3}$ & 9781 & 520 & 268 & 3 & 397 & 239 & 44069 & 965 & 2692 & 45 \\
\hline Standard $\mathrm{A}^{3}$ & 9718 & 526 & 267 & 4 & 399 & 262 & 44116 & 986 & 2680 & 43 \\
\hline Standard $\mathrm{A}^{3}$ & 9749 & 519 & 268 & 5 & 395 & 254 & 43616 & 983 & 2628 & 47 \\
\hline Average & 9651 & 523 & 266 & 4 & 395 & 255 & 42965 & 970 & 2641 & 44 \\
\hline STDEV & 190 & 10 & 3 & 1 & 3 & 9 & 1731 & 19 & 48 & 3 \\
\hline$\%$ RSD & 2 & 2 & 1 & 18 & 1 & 4 & 4 & 2 & 2 & 8 \\
\hline Blank & 80 & 16 & 1 & 0 & 2 & 70 & 0 & 4 & 0 & 0 \\
\hline Blank & 63 & 7 & 1 & 0 & 2 & 59 & 0 & 6 & 2 & 0 \\
\hline Blank & 77 & 0 & 0 & 0 & 1 & 66 & 0 & 3 & 0 & 0 \\
\hline Blank & 122 & 5 & 2 & 0 & 1 & 61 & 0 & 13 & 0 & 0 \\
\hline Blank & 69 & 9 & 2 & 0 & 0 & 51 & 0 & 24 & 0 & 0 \\
\hline
\end{tabular}

High Purity standards B, C, D, and E were used to calibrate the instrument.

${ }^{2}$ High Purity standard $\mathrm{D}$ was used as the drift monitor.

${ }^{3}$ High Purity standard A was used as the check standard. 
WSRC-STI-2007-00438

SRNL-RPP-2007-00020

\section{Table E - 4. Quality Control Check Standards Analysis for the Basic and Acidified} Runs.

The instrument was calibrated using five High Purity standards for each run.

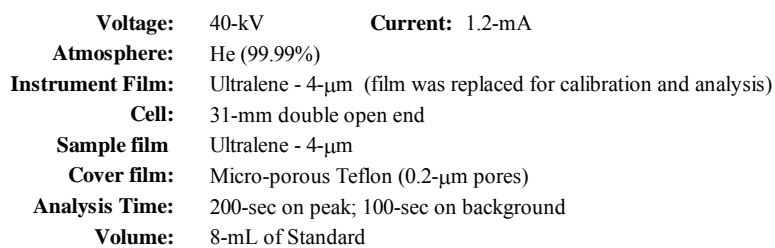

\begin{tabular}{|c|c|c|c|c|c|c|c|c|c|c|}
\hline & $\begin{array}{c}\text { Al } \\
\mu \mathrm{g} / \mathrm{mL}\end{array}$ & $\begin{array}{c}\text { Ca } \\
\mu \mathrm{g} / \mathrm{mL}\end{array}$ & $\begin{array}{c}\mathrm{Cr} \\
\mu \mathrm{g} / \mathrm{mL} \\
\end{array}$ & $\begin{array}{c}\text { Mo } \\
\mu \mathrm{g} / \mathrm{mL}\end{array}$ & $\begin{array}{c}\mathrm{Ni} \\
\mu \mathrm{g} / \mathrm{mL}\end{array}$ & $\begin{array}{c}\mathrm{K} \\
\mu \mathrm{g} / \mathrm{mL} \\
\end{array}$ & $\begin{array}{c}\mathrm{Na} \\
\mu \mathrm{g} / \mathrm{mL}\end{array}$ & $\begin{array}{c}\mathrm{SO}_{4} \\
\mu \mathrm{g} / \mathrm{mL}\end{array}$ & $\begin{array}{c}\mathrm{PO}_{4} \\
\mu \mathrm{g} / \mathrm{mL} \\
\end{array}$ & $\begin{array}{c}\mathrm{Cl} \\
\mu \mathrm{g} / \mathrm{mL} \\
\end{array}$ \\
\hline Standard A & 9315 & 523 & 262 & 5 & 383 & 258 & 40808 & 929 & 2487 & 37 \\
\hline $\mathrm{C}$ of $\mathrm{A}$ & 8850 & 500 & 250 & 5 & 375 & 225 & 36500 & 900 & 2450 & 50 \\
\hline Standard B & 3693 & $<10$ & 80 & 11 & 5 & 16905 & 67020 & 1968 & 638 & 859 \\
\hline $\mathrm{C}$ of $\mathrm{A}$ & 3650 & 5 & 85 & 10 & 5 & 17000 & 64500 & 1950 & 650 & 800 \\
\hline Standard C & 9280 & 130 & 386 & 48 & 127 & 2352 & 60590 & 9386 & 1021 & 133 \\
\hline Standard D & 9221 & 378 & 892 & 61 & 735 & 3333 & 62353 & 18704 & 714 & 57 \\
\hline $\mathrm{C}$ of $\mathrm{A}$ & 9600 & 400 & 900 & 60 & 750 & 3400 & 65800 & 19000 & 750 & 70 \\
\hline Standard E & 8980 & 39 & 294 & 30 & 37 & 3128 & 89164 & 2361 & 1174 & 2107 \\
\hline $\mathrm{C}$ of $\mathrm{A}$ & 9150 & 40 & 300 & 30 & 40 & 3250 & 89000 & 2400 & 1200 & 2150 \\
\hline Standard C & 9229 & 115 & 396 & 51 & 130 & 2343 & 58949 & 9629 & 1039 & 122 \\
\hline Standard B & 3589 & $<10$ & 89 & 12 & 3 & 16914 & 63300 & 1932 & 644 & 855 \\
\hline $\mathrm{C}$ of $\mathrm{A}$ & 3650 & 5 & 85 & 10 & 5 & 17000 & 64500 & 1950 & 650 & 800 \\
\hline Standard C & 9732 & 121 & 402 & 50 & 130 & 2455 & 63370 & 9869 & 1085 & 135 \\
\hline $\mathrm{C}$ of $\mathrm{A}$ & 9500 & 125 & 400 & 50 & 130 & 2400 & 62000 & 9650 & 1050 & 135 \\
\hline Standard D & 9830 & 388 & 905 & 62 & 758 & 3408 & 68631 & 19225 & 791 & 52 \\
\hline $\mathrm{C}$ of $\mathrm{A}$ & 9600 & 400 & 900 & 60 & 750 & 3400 & 65800 & 19000 & 750 & 70 \\
\hline Standard E & 8892 & 44 & 291 & 29 & 36 & 3124 & 90938 & 2331 & 1107 & 2122 \\
\hline $\mathrm{C}$ of $\mathrm{A}$ & 9150 & 40 & 300 & 30 & 40 & 3250 & 89000 & 2400 & 1200 & 2150 \\
\hline Standard B & 3804 & $<10$ & 86 & 10 & 4 & 17214 & 67835 & 2004 & 696 & 669 \\
\hline
\end{tabular}

C of A - Certificate of Analysis 
WSRC-STI-2007-00438

SRNL-RPP-2007-00020

\subsection{Appendix F: IC and ICP Simulant and Standard Data}

Table F - 1. IC Data for Envelope A, AN-105 Simulant.

\begin{tabular}{ccc}
\hline \hline & $\begin{array}{c}\text { Cl } \\
\text { mg/L }\end{array}$ & $\begin{array}{c}\text { SO }_{4} \\
\text { mg/L }\end{array}$ \\
\hline \hline AN-105 & 4500 & 148 \\
AN-105 & 4610 & 119 \\
AN-105 & 4700 & 137 \\
AN-105 & 4540 & 152 \\
AN-105 & 4660 & 146 \\
\hline Average & 4600 & 140 \\
STDEV & 83 & 13 \\
\%RSD & 2 & 9 \\
\hline \hline
\end{tabular}

Table F - 2. ICP Data for Envelope A, AN-105 Simulant.

\begin{tabular}{|c|c|c|c|c|c|c|c|c|}
\hline & $\begin{array}{c}\mathrm{Ag} \\
\mathrm{mg} / \mathrm{L}\end{array}$ & $\begin{array}{c}\mathrm{Al} \\
\mathrm{mg} / \mathrm{L}\end{array}$ & $\begin{array}{c}\text { B } \\
\mathrm{mg} / \mathrm{L}\end{array}$ & $\begin{array}{c}\text { Ca } \\
\mathrm{mg} / \mathrm{L}\end{array}$ & $\begin{array}{c}\mathrm{Cd} \\
\mathrm{mg} / \mathrm{L}\end{array}$ & $\begin{array}{c}\mathrm{Cr} \\
\mathrm{mg} / \mathrm{L}\end{array}$ & $\begin{array}{c}\text { Fe } \\
\mathrm{mg} / \mathrm{L}\end{array}$ & $\begin{array}{c}\mathrm{K} \\
\mathrm{mg} / \mathrm{L}\end{array}$ \\
\hline AN-105 & 3.25 & 10900 & 23.9 & $<3.81$ & 2.02 & 645 & 1.19 & 3850 \\
\hline AN-105 & 2.94 & 10800 & 28.4 & $<3.81$ & 2.61 & 663 & 0.714 & 3710 \\
\hline AN-105 & 2.83 & 10900 & 25.9 & $<1.29$ & 2.42 & 664 & 1.00 & 3720 \\
\hline AN-105 & 3.90 & 10900 & 26.4 & $<1.29$ & 2.57 & 656 & 1.04 & 3780 \\
\hline AN-105 & 3.53 & 10900 & 26.6 & $<1.29$ & 2.48 & 668 & 0.935 & 3980 \\
\hline AN-105 & 3.52 & 11000 & 24.6 & $<1.29$ & 2.21 & 666 & 1.63 & 3970 \\
\hline AN-105 & 3.24 & 9780 & 21.7 & $<1.29$ & 1.83 & 573 & 1.05 & 3480 \\
\hline AN-105 & 2.58 & 9560 & 22.2 & $<1.29$ & 1.73 & 580 & 0.503 & 3450 \\
\hline AN-105 & 3.43 & 10700 & 24.6 & $<1.29$ & 2.37 & 644 & 0.755 & 3860 \\
\hline AN-105 & 3.07 & 10900 & 15.3 & $<1.29$ & 2.24 & 636 & 0.731 & 3870 \\
\hline Average & 3.23 & 10600 & 24.0 & & 2.25 & 640 & 0.95 & 3770 \\
\hline STDEV & 0.4 & 517 & 4 & & 0.3 & 35 & 0.3 & 183 \\
\hline \%RSD & 12 & 5 & 15 & & 14 & 5 & 33 & 5 \\
\hline & $\begin{array}{c}\text { Mo } \\
\mathrm{mg} / \mathrm{L}\end{array}$ & $\begin{array}{c}\mathrm{Na} \\
\mathrm{mg} / \mathrm{L}\end{array}$ & $\begin{array}{c}\mathrm{Ni} \\
\mathrm{mg} / \mathrm{L}\end{array}$ & $\begin{array}{c}\mathrm{PO}_{4} \\
\mathrm{mg} / \mathrm{L}\end{array}$ & $\begin{array}{c}\mathbf{P b} \\
\mathrm{mg} / \mathrm{L}\end{array}$ & $\begin{array}{r}\mathrm{SO}_{4} \\
\mathrm{mg} / \mathrm{L}\end{array}$ & $\begin{array}{c}\mathrm{Si} \\
\mathrm{mg} / \mathrm{L}\end{array}$ & $\begin{array}{c}\mathrm{Zn} \\
\mathrm{mg} / \mathrm{L}\end{array}$ \\
\hline AN-105 & 39.2 & 128000 & 1.16 & 280 & 15.2 & 422 & 84.3 & 5.59 \\
\hline AN-105 & 41.8 & 120000 & $<0.558$ & 313 & 17.1 & 416 & 88.0 & 5.71 \\
\hline AN-105 & 41.3 & 124000 & $<0.349$ & 298 & 16.8 & 407 & 84.5 & 5.48 \\
\hline AN-105 & 40.8 & 123000 & $<0.349$ & 296 & 17.6 & 398 & 82.1 & 5.42 \\
\hline AN-105 & 41.6 & 127000 & $<0.349$ & 297 & 18.2 & 407 & 81.9 & 5.77 \\
\hline AN-105 & 39.7 & 129000 & 0.592 & 291 & 15.1 & 401 & 84.2 & 5.31 \\
\hline AN-105 & 35.4 & 113000 & 0.392 & 261 & 13.6 & 357 & 71.1 & 4.70 \\
\hline AN-105 & 35.9 & 110000 & $<0.349$ & 270 & 16.4 & 357 & 81.2 & 5.15 \\
\hline AN-105 & 40.0 & 124000 & $<0.349$ & 298 & 17.1 & 407 & 83.1 & 5.01 \\
\hline AN-105 & 41.9 & 126000 & $<0.349$ & 284 & 16.8 & 410 & 82.2 & 4.76 \\
\hline Average & 39.8 & 122000 & & 289 & 16.4 & 398 & 82.3 & 5.29 \\
\hline STDEV & 2 & 6346 & & 15 & 1 & 23 & 4 & 0.4 \\
\hline \%RSD & 6 & 5 & & 5 & 8 & 6 & 5 & 7 \\
\hline
\end{tabular}


WSRC-STI-2007-00438

SRNL-RPP-2007-00020

Table F - 3. IC Data for Envelope A, AP-101 Simulant.

\begin{tabular}{ccc}
\hline \hline & $\begin{array}{c}\mathbf{C l} \\
\mathbf{m g} / \mathbf{L}\end{array}$ & $\begin{array}{c}\mathbf{S O}_{\mathbf{4}} \\
\mathbf{m g} / \mathbf{L}\end{array}$ \\
\hline \hline AP-101 & 1460 & 3460 \\
AP-101 & 1490 & 3390 \\
AP-101 & 1500 & 3440 \\
AP-101 & 1510 & 3460 \\
AP-101 & 1510 & 3480 \\
\hline Average & 1490 & 3450 \\
STDEV & 21 & 34 \\
\%RSD & 1 & 1 \\
\hline \hline
\end{tabular}

Table F - 4. ICP Data for Envelope A, AP-101 Simulant.

\begin{tabular}{|c|c|c|c|c|c|c|c|c|}
\hline & $\begin{array}{c}\mathrm{Al} \\
\mathrm{mg} / \mathrm{L}\end{array}$ & $\begin{array}{c}\text { B } \\
\mathrm{mg} / \mathrm{L}\end{array}$ & $\begin{array}{c}\text { Ba } \\
\mathrm{mg} / \mathrm{L}\end{array}$ & $\begin{array}{c}\mathrm{Ca} \\
\mathrm{mg} / \mathrm{L}\end{array}$ & $\begin{array}{c}\text { Cd } \\
\mathrm{mg} / \mathrm{L}\end{array}$ & $\begin{array}{c}\mathrm{Cr} \\
\mathrm{mg} / \mathrm{L}\end{array}$ & $\begin{array}{c}\text { Fe } \\
\mathrm{mg} / \mathrm{L}\end{array}$ & $\begin{array}{c}\mathrm{K} \\
\mathrm{mg} / \mathrm{L}\end{array}$ \\
\hline AP-101 & 6750 & 11.7 & 0.532 & $<3.81$ & 0.975 & 148 & 2.36 & 27600 \\
\hline AP-101 & 6730 & 13.8 & 0.675 & $<3.81$ & 1.44 & 146 & 1.84 & 27200 \\
\hline AP-101 & 6820 & 12.5 & 0.562 & $<1.29$ & 1.31 & 154 & 2.35 & 27300 \\
\hline AP-101 & 6860 & 12.5 & 0.575 & $<1.29$ & 1.22 & 149 & 2.50 & 27900 \\
\hline AP-101 & 6910 & 13.3 & 0.584 & $<1.29$ & 1.39 & 159 & 2.44 & 28900 \\
\hline AP-101 & 6910 & 12.7 & 0.575 & $<1.29$ & 1.19 & 156 & 2.63 & 29000 \\
\hline AP-101 & 7050 & 12.8 & 0.610 & $<1.29$ & 1.18 & 154 & 2.43 & 29000 \\
\hline AP-101 & 6880 & 12.5 & 0.721 & $<1.29$ & 1.51 & 154 & 1.60 & 28400 \\
\hline AP-101 & 6730 & 11.9 & 0.638 & $<1.29$ & 1.26 & 147 & 1.88 & 28100 \\
\hline AP-101 & 6830 & 2.46 & 0.581 & $<1.29$ & 1.30 & 148 & 1.83 & 28300 \\
\hline Average & 6850 & 11.6 & 0.605 & & 1.28 & 152 & 2.19 & 28200 \\
\hline STDEV & 99 & 3 & 0.1 & & 0.2 & 4 & 0.4 & 673 \\
\hline \%RSD & 1 & 28 & 9 & & 12 & 3 & 16 & 2 \\
\hline & $\begin{array}{r}\text { Mo } \\
\text { mg/L } \\
\end{array}$ & $\begin{array}{c}\mathrm{Na} \\
\mathrm{mg} / \mathrm{L}\end{array}$ & $\begin{array}{c}\mathrm{Ni} \\
\mathrm{mg} / \mathrm{L}\end{array}$ & $\begin{array}{c}\mathrm{PO}_{4} \\
\mathrm{mg} / \mathrm{L}\end{array}$ & $\begin{array}{c}\mathrm{Pb} \\
\mathrm{mg} / \mathrm{L}\end{array}$ & $\begin{array}{c}\mathrm{SO}_{4} \\
\mathrm{mg} / \mathrm{L}\end{array}$ & $\begin{array}{c}\text { Si } \\
\mathrm{mg} / \mathrm{L}\end{array}$ & $\begin{array}{c}\mathrm{Zn} \\
\mathrm{mg} / \mathrm{L}\end{array}$ \\
\hline AP-101 & 13.3 & 124000 & 1.10 & 1254 & 7.12 & 3835 & 54.7 & 5.08 \\
\hline AP-101 & 13.0 & 113000 & $<0.558$ & 1141 & 7.52 & 3745 & 54.6 & 4.91 \\
\hline AP-101 & 13.8 & 117000 & $<0.349$ & 1220 & 10.1 & 3685 & 55.2 & 5.04 \\
\hline AP-101 & 13.3 & 120000 & 0.396 & 1153 & 7.39 & 3805 & 52.2 & 4.87 \\
\hline AP-101 & 14.5 & 121000 & $<0.349$ & 1251 & 10.6 & 3835 & 54.3 & 5.40 \\
\hline AP-101 & 13.3 & 123000 & $<0.349$ & 1233 & 8.52 & 3775 & 55.7 & 4.89 \\
\hline AP-101 & 13.6 & 123000 & $<0.349$ & 1214 & 8.46 & 3955 & 54.5 & 4.97 \\
\hline AP-101 & 13.7 & 119000 & $<0.349$ & 1239 & 9.85 & 3805 & 56.7 & 5.47 \\
\hline AP-101 & 12.7 & 119000 & $<0.349$ & 1196 & 9.05 & 3715 & 53.3 & 4.39 \\
\hline AP-101 & 14.6 & 118000 & $<0.349$ & 1177 & 9.64 & 3955 & 54.6 & 4.37 \\
\hline Average & 13.6 & 120000 & & 1210 & 8.83 & 3810 & 54.6 & 4.94 \\
\hline STDEV & 0.6 & 3302 & & 40 & 1 & 90 & 1 & 0.4 \\
\hline \%RSD & 4 & 3 & & 3 & 14 & 2 & 2 & 7 \\
\hline
\end{tabular}


WSRC-STI-2007-00438

SRNL-RPP-2007-00020

Table F - 5. IC Data for Envelope C, AN-107 Simulant.

\begin{tabular}{ccc}
\hline \hline & $\begin{array}{c}\mathbf{C l} \\
\mathbf{m g} / \mathbf{L}\end{array}$ & $\begin{array}{c}\mathbf{S O}_{\mathbf{4}} \\
\mathbf{m g} / \mathbf{L}\end{array}$ \\
\hline \hline AN-107 & 1390 & 4720 \\
AN-107 & 1390 & 4630 \\
AN-107 & 1380 & 4770 \\
AN-107 & 1690 & 4760 \\
AN-107 & 1650 & 4680 \\
\hline Average & 1500 & 4710 \\
STDEV & 156 & 58 \\
\%RSD & 10 & 1 \\
\hline \hline
\end{tabular}

Table F - 6. ICP Data for Envelope C, AN-107 Simulant.

\begin{tabular}{|c|c|c|c|c|c|c|c|c|c|}
\hline & $\begin{array}{c}\mathrm{Al} \\
\mathrm{mg} / \mathrm{L}\end{array}$ & $\begin{array}{c}\text { B } \\
\mathrm{mg} / \mathrm{L}\end{array}$ & $\begin{array}{c}\mathrm{Ca} \\
\mathrm{mg} / \mathrm{L}\end{array}$ & $\begin{array}{c}\mathrm{Cr} \\
\mathrm{mg} / \mathrm{L}\end{array}$ & $\begin{array}{c}\mathrm{Cu} \\
\mathrm{mg} / \mathrm{L}\end{array}$ & $\begin{array}{c}\mathrm{Fe} \\
\mathrm{mg} / \mathrm{L}\end{array}$ & $\begin{array}{c}\mathrm{K} \\
\mathrm{mg} / \mathrm{L}\end{array}$ & $\begin{array}{c}\mathrm{La} \\
\mathrm{mg} / \mathrm{L}\end{array}$ & $\begin{array}{c}\mathrm{Mn} \\
\mathrm{mg} / \mathrm{L}\end{array}$ \\
\hline AN-107 & 23235 & 1818.9 & 10147 & 0.326 & 9.89 & 1313.0 & "1190 & $=1.04$ & 0.298 \\
\hline AN-107 & 232 & 21.9 & 145 & 0.518 & 11.5 & 12.4 & 1130 & 0.86 & 0.205 \\
\hline AN-107 & 233 & 19.7 & 140 & 0.711 & 11.2 & 12.6 & 1200 & 0.697 & $<0.515$ \\
\hline AN-107 & 238 & 19.8 & 142 & 0.605 & 11.3 & 12.7 & 1180 & 1.23 & $<0.515$ \\
\hline AN-107 & 237 & 20.2 & 147 & 0.633 & 12.1 & 12.6 & 1250 & 1.47 & $<0.515$ \\
\hline AN-107 & 237 & 19.2 & 147 & 0.676 & 11.7 & 13.1 & 1220 & 1.03 & $<0.515$ \\
\hline AN-107 & 241 & 20.0 & 150 & 1.19 & 12.3 & 15.4 & 1300 & 1.12 & 0.589 \\
\hline AN-107 & 241 & 19.6 & 147 & 0.659 & 11.5 & 12.1 & 1270 & 1.31 & $<0.515$ \\
\hline AN-107 & 233 & 19.0 & 142 & 0.618 & 11.0 & 12.1 & 1180 & 1.04 & $<0.515$ \\
\hline AN-107 & 236 & 9.81 & 145 & 0.498 & 10.2 & 12.5 & 1070 & 1.19 & $<0.515$ \\
\hline Average & 236 & 18.8 & 145 & 0.643 & 11.3 & 12.9 & 1200 & 1.10 & \\
\hline STDEV & 3 & 3 & 3 & 0.2 & 1 & 1 & 67 & 0 & \\
\hline$\%$ RSD & 1 & 17 & 2 & 35 & 7 & 7 & 6 & 20 & \\
\hline & $\begin{array}{c}\mathrm{Mo} \\
\mathrm{mg} / \mathrm{L}\end{array}$ & $\begin{array}{c}\mathrm{Na} \\
\mathrm{mg} / \mathrm{L}\end{array}$ & $\begin{array}{c}\mathrm{Ni} \\
\mathrm{mg} / \mathrm{L}\end{array}$ & $\begin{array}{c}\mathrm{PO}_{4} \\
\mathrm{mg} / \mathrm{L}\end{array}$ & $\begin{array}{c}\mathrm{SO}_{4} \\
\mathrm{mg} / \mathrm{L}\end{array}$ & $\begin{array}{c}\mathrm{Si} \\
\mathrm{mg} / \mathrm{L}\end{array}$ & $\begin{array}{c}\mathrm{Sr} \\
\mathrm{mg} / \mathrm{L}\end{array}$ & $\begin{array}{c}\mathrm{Zn} \\
\mathrm{mg} / \mathrm{L}\end{array}$ & $\begin{array}{c}\mathrm{Zr} \\
\mathrm{mg} / \mathrm{L}\end{array}$ \\
\hline "AN-107 & 21.4 & $=147000$ & 29290 & 905 & 525273 & 7.9 .95 & 80.1 & 1818.0 & 0.625 \\
\hline AN-107 & 22.1 & 130000 & 288 & 862 & 5033 & 10.5 & 73.9 & 17.5 & 0.829 \\
\hline AN-107 & 21.5 & 137000 & 301 & 874 & 5003 & 7.45 & 72.3 & 17.5 & $<35.0$ \\
\hline AN-107 & 22.1 & 142000 & 302 & 883 & 5123 & 13.3 & 74.2 & 17.8 & $<35.0$ \\
\hline AN-107 & 21.9 & 144000 & 309 & 895 & 5273 & 6.88 & 77.1 & 17.9 & $<35.0$ \\
\hline AN-107 & 21.2 & 144000 & 307 & 892 & 5243 & 8.87 & 77.8 & 18.3 & $<35.0$ \\
\hline AN-107 & 22.2 & 145000 & 314 & 905 & 5393 & 10.1 & 77.1 & 18.4 & $<35.0$ \\
\hline AN-107 & 21.4 & 140000 & 303 & 908 & 5123 & 9.62 & 69.3 & 18.3 & $<35.0$ \\
\hline AN-107 & 21.0 & 141000 & 294 & 905 & 5213 & 9.08 & 69.9 & 17.1 & $<35.0$ \\
\hline AN-107 & 23.4 & 141000 & 306 & 917 & 5363 & 10.7 & 78.3 & 17.5 & $<35.0$ \\
\hline Average & 21.8 & 141000 & 301 & 894 & 5200 & 9.45 & 75.0 & 17.8 & \\
\hline STDEV & 0.7 & 4818 & 8 & 17 & 131 & 2 & 4 & 0.4 & \\
\hline \%RSD & 3 & 3 & 3 & 2 & 3 & 20 & 5 & 2 & \\
\hline
\end{tabular}


WSRC-STI-2007-00438

SRNL-RPP-2007-00020

Table F - 7. IC Data for Envelope B/D, AZ-101 Simulant.

\begin{tabular}{ccc}
\hline \hline & $\begin{array}{c}\mathbf{C l} \\
\mathbf{m g} / \mathbf{L}\end{array}$ & $\begin{array}{c}\mathbf{S O}_{\mathbf{4}} \\
\mathbf{m g} / \mathbf{L}\end{array}$ \\
\hline \hline $\mathrm{AZ}-101$ & 248 & 743 \\
$\mathrm{AZ}-101$ & 282 & 685 \\
$\mathrm{AZ}-101$ & 263 & 826 \\
$\mathrm{AZ}-101$ & 254 & 740 \\
$\mathrm{AZ}-101$ & 247 & 744 \\
\hline Average & 259 & 748 \\
STDEV & 14 & 50 \\
\%RSD & 6 & 7 \\
\hline \hline
\end{tabular}

Table F - 8. ICP Data for Envelope B/D, AZ-101 Simulant.

\begin{tabular}{|c|c|c|c|c|c|c|c|c|c|}
\hline & $\begin{array}{c}\text { Al } \\
\mathrm{mg} / \mathrm{L}\end{array}$ & $\begin{array}{c}\mathrm{Ca} \\
\mathrm{mg} / \mathrm{L}\end{array}$ & $\begin{array}{c}\mathrm{Cr} \\
\mathrm{mg} / \mathrm{L}\end{array}$ & $\begin{array}{c}\mathrm{K} \\
\mathrm{mg} / \mathrm{L}\end{array}$ & $\begin{array}{c}\text { Mo } \\
\text { mg/L }\end{array}$ & $\begin{array}{c}\mathrm{Na} \\
\mathrm{mg} / \mathrm{L}\end{array}$ & $\begin{array}{c}\mathrm{Ni} \\
\mathrm{mg} / \mathrm{L}\end{array}$ & $\begin{array}{c}\mathrm{PO}_{4} \\
\mathrm{mg} / \mathrm{L}\end{array}$ & $\begin{array}{r}\mathrm{SO}_{4} \\
\mathrm{mg} / \mathrm{L} \\
\end{array}$ \\
\hline AZ-101 & $<2.56$ & $<3.81$ & 140 & 759 & 25.9 & 11500 & $<0.558$ & $<80$ & 767 \\
\hline AZ-101 & $<2.56$ & $<3.81$ & 139 & 762 & 25.0 & 11200 & $<0.558$ & $<80$ & 797 \\
\hline AZ-101 & $<4.70$ & $<1.29$ & 142 & 761 & 25.1 & 11300 & 0.36 & $<60$ & 782 \\
\hline AZ-101 & $<4.70$ & $<1.29$ & 141 & 760 & 25.7 & 11300 & $<0.349$ & $<60$ & 800 \\
\hline AZ-101 & $<4.70$ & $<1.29$ & 144 & 805 & 26.0 & 11600 & $<0.349$ & $<60$ & 809 \\
\hline AZ-101 & $<4.70$ & $<1.29$ & 145 & 820 & 25.0 & 11800 & 0.642 & $<60$ & 797 \\
\hline AZ-101 & $<4.70$ & $<1.29$ & 148 & 823 & 26.3 & 12000 & $<0.349$ & $<60$ & 836 \\
\hline AZ-101 & $<4.70$ & $<1.29$ & 141 & 779 & 24.6 & 11400 & $<0.349$ & $<60$ & 785 \\
\hline AZ-101 & $<4.70$ & $<1.29$ & 140 & 780 & 24.7 & 11400 & $<0.349$ & $<60$ & 812 \\
\hline AZ-101 & $<4.70$ & $<1.29$ & 142 & 765 & 26.7 & 11600 & $<0.349$ & $<60$ & 830 \\
\hline Average & & & 142 & 781 & 25.5 & 11500 & & & 800 \\
\hline STDEV & & & 3 & 25 & 0.7 & 247 & & & 21 \\
\hline \%RSD & & & 2 & 3 & 3 & 2 & & & 3 \\
\hline
\end{tabular}


WSRC-STI-2007-00438

SRNL-RPP-2007-00020

Table F - 9. IC Data for High Purity Standard A.

\begin{tabular}{ccc}
\hline \hline & $\begin{array}{c}\mathbf{C l} \\
\mathbf{m g} / \mathbf{L}\end{array}$ & $\begin{array}{c}\mathbf{S O}_{\mathbf{4}} \\
\mathbf{m g} / \mathbf{L}\end{array}$ \\
\hline \hline Standard A & $<100$ & 3850 \\
Standard A & $<100$ & 3540 \\
Standard A & $<100$ & 3460 \\
Standard A & $<100$ & 3420 \\
Standard A & $<100$ & 3540 \\
\hline C of A & 50 & 900 \\
Average & & 3560 \\
STDEV & & 169 \\
\%RSD & & 5 \\
\hline \hline
\end{tabular}

C of A - Certificate of Analysis

Table F - 10. ICP Data for High Purity Standard A.

\begin{tabular}{|c|c|c|c|c|c|c|c|c|c|}
\hline & $\begin{array}{c}\text { Al } \\
\mathrm{mg} / \mathrm{L}\end{array}$ & $\begin{array}{c}\mathrm{Ca} \\
\mathrm{mg} / \mathrm{L}\end{array}$ & $\begin{array}{c}\mathrm{Cr} \\
\mathrm{mg} / \mathrm{L}\end{array}$ & $\begin{array}{c}\mathrm{K} \\
\mathrm{mg} / \mathrm{L}\end{array}$ & $\begin{array}{c}\text { Mo } \\
\text { mg/L }\end{array}$ & $\begin{array}{c}\mathrm{Na} \\
\mathrm{mg} / \mathrm{L}\end{array}$ & $\begin{array}{c}\mathrm{Ni} \\
\mathrm{mg} / \mathrm{L}\end{array}$ & $\begin{array}{c}\mathrm{PO}_{4} \\
\mathrm{mg} / \mathrm{L}\end{array}$ & $\begin{array}{c}\mathrm{SO}_{4} \\
\mathrm{mg} / \mathrm{L}\end{array}$ \\
\hline Standard A & 8860 & 493 & 252 & 229 & 5.39 & 37400 & 372 & 2401 & 965 \\
\hline Standard A & 8580 & 489 & 245 & 215 & 5.31 & 35300 & 359 & 2220 & 926 \\
\hline Standard A & 8770 & 489 & 255 & 225 & 5.85 & 37100 & 381 & 2315 & 938 \\
\hline Standard A & 8710 & 486 & 251 & 229 & 5.41 & 36700 & 372 & 2263 & 956 \\
\hline Standard A & 8760 & 502 & 257 & 231 & 5.92 & 37300 & 379 & 2343 & 971 \\
\hline Standard A & 8760 & 505 & 258 & 237 & 5.52 & 37600 & 382 & 2376 & 938 \\
\hline Standard A & 8670 & 502 & 254 & 237 & 5.60 & 36600 & 380 & 2315 & 962 \\
\hline Standard A & 8680 & 500 & 253 & 238 & 5.09 & 36800 & 374 & 2318 & 941 \\
\hline Standard A & 8560 & 485 & 249 & 226 & 4.94 & 36700 & 363 & 2340 & 953 \\
\hline Standard A & 8690 & 497 & 254 & 229 & 5.96 & 36300 & 381 & 2297 & 971 \\
\hline$C$ of $A$ & 8850 & 500 & 250 & 225 & 5 & 36500 & 375 & 2450 & 900 \\
\hline Average & 8700 & 495 & 253 & 230 & 5.50 & 36800 & 374 & 2320 & 952 \\
\hline Stdev & 90 & 7 & 4 & 7 & 0.3 & 658 & 8 & 52 & 16 \\
\hline \%RSD & 1 & 1 & 2 & 3 & 6 & 2 & 2 & 2 & 2 \\
\hline
\end{tabular}

C of A - Certificate of Analysis 
WSRC-STI-2007-00438

SRNL-RPP-2007-00020

Table F - 11. IC Data for High Purity Standard B.

\begin{tabular}{ccc}
\hline \hline & $\begin{array}{c}\mathbf{C l} \\
\mathbf{m g} / \mathbf{L}\end{array}$ & $\begin{array}{c}\mathbf{S O}_{\mathbf{4}} \\
\mathbf{m g} / \mathbf{L}\end{array}$ \\
\hline \hline Standard B & 854 & 7800 \\
Standard B & 883 & 7380 \\
Standard B & 856 & 6810 \\
Standard B & 824 & 6970 \\
Standard B & 824 & 6860 \\
\hline C of A & 800 & 1950 \\
Average & 848 & 7160 \\
STDEV & 25 & 420 \\
\%RSD & 3 & 6 \\
\hline \hline
\end{tabular}

C of A - Certificate of Analysis

Table F - 12. ICP Data for High Purity Standard B.

\begin{tabular}{|c|c|c|c|c|c|c|c|c|c|}
\hline & $\begin{array}{c}\mathrm{Al} \\
\mathrm{mg} / \mathrm{L}\end{array}$ & $\begin{array}{c}\mathrm{Ca} \\
\mathrm{mg} / \mathrm{L}\end{array}$ & $\begin{array}{c}\mathrm{Cr} \\
\mathrm{mg} / \mathrm{L}\end{array}$ & $\begin{array}{c}\mathrm{K} \\
\mathrm{mg} / \mathrm{L}\end{array}$ & $\begin{array}{c}\text { Mo } \\
\text { mg/L }\end{array}$ & $\begin{array}{c}\mathrm{Na} \\
\mathrm{mg} / \mathrm{L}\end{array}$ & $\begin{array}{c}\mathrm{Ni} \\
\mathrm{mg} / \mathrm{L}\end{array}$ & $\begin{array}{c}\mathrm{PO}_{4} \\
\mathrm{mg} / \mathrm{L}\end{array}$ & $\begin{array}{c}\mathrm{SO}_{4} \\
\mathrm{mg} / \mathrm{L}\end{array}$ \\
\hline Standard B & 3650 & $4 \quad 4.72$ & 85.6 & $\overline{17500}$ & 10.5 & (265700 & 5.91 & 6619 & 2085 \\
\hline Standard B & 3580 & 5.01 & 82.5 & 16700 & 10.0 & 62800 & 4.67 & 586 & 1980 \\
\hline Standard B & 3430 & 3.46 & 83.6 & 15800 & 10.3 & 63200 & 4.83 & 626 & 1983 \\
\hline Standard B & 3600 & 4.79 & 82.7 & 17000 & 9.99 & 66300 & 4.94 & 592 & 1983 \\
\hline Standard B & 3550 & 5.00 & 84.6 & 17200 & 10.4 & 64900 & 4.70 & 626 & 2031 \\
\hline Standard B & 3620 & 5.25 & 86.0 & 17700 & 10.2 & 66800 & 4.93 & 635 & 2040 \\
\hline Standard B & 3540 & 5.86 & 83.9 & 16800 & 9.82 & 64800 & 5.16 & 607 & 2025 \\
\hline Standard B & 3600 & 4.59 & 85.2 & 17300 & 9.86 & 66000 & 4.49 & 626 & 2037 \\
\hline Standard B & 3470 & 4.43 & 82.3 & 16800 & 9.26 & 63700 & 4.61 & 610 & 2007 \\
\hline Standard B & 3530 & 5.14 & 85.1 & 16700 & 10.9 & 64100 & 4.31 & 622 & 2124 \\
\hline C of $A$ & 3650 & 5 & 85 & 17000 & 10 & 64500 & 5 & 650 & 1950 \\
\hline Average & 3560 & 4.83 & 84.2 & 17000 & 10.1 & 64800 & 4.86 & 615 & 2030 \\
\hline STDEV & 68 & 0.6 & 1 & 532 & 0.4 & 1365 & 0.4 & 16 & 46 \\
\hline \%RSD & 2 & 13 & 2 & 3 & 4 & 2 & 9 & 3 & 2 \\
\hline
\end{tabular}

C of A - Certificate of Analysis 
WSRC-STI-2007-00438

SRNL-RPP-2007-00020

Table F - 13. IC Data for High Purity Standard C.

\begin{tabular}{ccc}
\hline \hline & $\begin{array}{c}\mathbf{C l} \\
\mathbf{m g} / \mathbf{L}\end{array}$ & $\begin{array}{c}\mathbf{S O}_{\mathbf{4}} \\
\mathbf{m g} / \mathbf{L}\end{array}$ \\
\hline \hline Standard C & 181 & 26400 \\
Standard C & 195 & 26100 \\
Standard C & 183 & 24200 \\
Standard C & 173 & 22000 \\
Standard C & 177 & 25100 \\
\hline C of A & 135 & 9650 \\
Average & 182 & 24800 \\
STDEV & 8 & 1770 \\
\%RSD & 5 & 7 \\
\hline \hline
\end{tabular}

C of A - Certificate of Analysis

Table F - 14. ICP Data for High Purity Standard C.

\begin{tabular}{|c|c|c|c|c|c|c|c|c|c|}
\hline & $\begin{array}{c}\mathrm{Al} \\
\mathrm{mg} / \mathrm{L}\end{array}$ & $\begin{array}{c}\mathrm{Ca} \\
\mathrm{mg} / \mathrm{L}\end{array}$ & $\begin{array}{c}\mathrm{Cr} \\
\mathrm{mg} / \mathrm{L}\end{array}$ & $\begin{array}{c}\mathrm{K} \\
\mathrm{mg} / \mathrm{L}\end{array}$ & $\begin{array}{c}\text { Mo } \\
\text { mg/L }\end{array}$ & $\begin{array}{c}\mathrm{Na} \\
\mathrm{mg} / \mathrm{L}\end{array}$ & $\begin{array}{c}\mathrm{Ni} \\
\mathrm{mg} / \mathrm{L}\end{array}$ & $\begin{array}{c}\mathrm{PO}_{4} \\
\mathrm{mg} / \mathrm{L}\end{array}$ & $\begin{array}{c}\mathrm{SO}_{4} \\
\mathrm{mg} / \mathrm{L}\end{array}$ \\
\hline$\overline{\text { Standard C }}$ & $9 \overline{9570}$ & 10128 & 8404 & 20 & 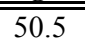 & "63200 & 10127 & 1033 & $\overline{10306}$ \\
\hline Standard C & 9290 & 126 & 390 & 2360 & 50.0 & 59500 & 124 & 951 & 9947 \\
\hline Standard C & 9300 & 119 & 388 & 2400 & 49.0 & 61200 & 126 & 966 & 9767 \\
\hline Standard C & 9160 & 121 & 388 & 2460 & 48.9 & 61800 & 127 & 944 & 9887 \\
\hline Standard C & 9400 & 128 & 404 & 2550 & 51.4 & 64000 & 132 & 1024 & 10097 \\
\hline Standard C & 9390 & 126 & 398 & 2370 & 49.7 & 64000 & 130 & 1024 & 10097 \\
\hline Standard C & 9240 & 125 & 390 & 2410 & 49.7 & 62600 & 129 & 984 & 9977 \\
\hline Standard C & 9160 & 121 & 379 & 2490 & 47.2 & 62600 & 123 & 954 & 9587 \\
\hline Standard C & 9090 & 120 & 380 & 2450 & 48.3 & 61200 & 119 & 975 & 9947 \\
\hline Standard C & 9100 & 123 & 387 & 2430 & 51.9 & 61500 & 126 & 972 & 10156 \\
\hline C of A & 9500 & 125 & 400 & 2400 & 50 & 62000 & 130 & 1050 & 9650 \\
\hline Average & 9270 & 124 & 391 & 2440 & 49.7 & 62200 & 126 & 983 & 9980 \\
\hline STDEV & 152 & 3 & 9 & 60 & 1 & 1403 & 4 & 33 & 204 \\
\hline \%RSD & 2 & 3 & 2 & 2 & 3 & 2 & 3 & 3 & 2 \\
\hline
\end{tabular}

C of A - Certificate of Analysis 
WSRC-STI-2007-00438

SRNL-RPP-2007-00020

Table F - 15. IC Data for High Purity Standard D.

\begin{tabular}{ccc}
\hline \hline & $\begin{array}{c}\mathbf{C l} \\
\mathbf{m g} / \mathbf{L}\end{array}$ & $\begin{array}{c}\mathbf{S O}_{\mathbf{4}} \\
\mathbf{m g} / \mathbf{L}\end{array}$ \\
\hline \hline Standard D & $<100$ & 45000 \\
Standard D & 199 & 40600 \\
Standard D & 116 & 41400 \\
Standard D & 101 & 39500 \\
Standard D & 121 & 41400 \\
\hline C of A & 70 & 19000 \\
Average & 134 & 41600 \\
STDEV & 44 & 2064 \\
\%RSD & 33 & 5 \\
\hline \hline
\end{tabular}

C of A - Certificate of Analysis

Table F - 16. ICP Data for High Purity Standard D.

\begin{tabular}{cccccccccc}
\hline \hline & $\mathbf{A l}$ & $\mathbf{C a}$ & $\mathbf{C r}$ & $\mathbf{K}$ & $\mathbf{M o}$ & $\mathbf{N a}$ & $\mathbf{N i}$ & $\begin{array}{c}\mathbf{P O}_{\mathbf{4}} \\
\mathbf{m g} / \mathbf{L}\end{array}$ & $\begin{array}{c}\mathbf{S O}_{\mathbf{4}} \\
\mathbf{m g} / \mathbf{L}\end{array}$ \\
\hline \hline Standard D & 9670 & 400 & 893 & 3520 & 60.2 & 67400 & 727 & 751 & 19953 \\
$\mathbf{m g} / \mathbf{m}$ & $\mathbf{m g} / \mathbf{L}$ & $\mathbf{m g} / \mathbf{L}$ & $\mathbf{m g} / \mathbf{L}$ & 705 & 19474 \\
Standard D & 9360 & 397 & 879 & 3280 & 60.7 & 64300 & 721 & 711 & 19444 \\
Standard D & 9460 & 392 & 892 & 3300 & 59.6 & 66300 & 741 & 705 & 19684 \\
Standard D & 9500 & 391 & 888 & 3430 & 60.6 & 66300 & 732 & 727 & 20043 \\
Standard D & 9600 & 407 & 909 & 3420 & 61.5 & 68600 & 755 & 742 & 20043 \\
Standard D & 9570 & 409 & 914 & 3450 & 61.2 & 69700 & 755 & 718 & 19983 \\
Standard D & 9480 & 403 & 897 & 3520 & 60.6 & 68700 & 742 & 718 & 19774 \\
Standard D & 9520 & 406 & 892 & 3570 & 59.9 & 68600 & 739 & 711 & 20013 \\
Standard D & 9310 & 390 & 876 & 3440 & 59.3 & 67700 & 711 & 708 & 20523 \\
Standard D & 9390 & 402 & 893 & 3360 & 64.2 & 65700 & 748 & 750 \\
\hline C of A & 9600 & 400 & 900 & 3400 & 60 & 65800 & 750 & 750 & 19000 \\
Average & 9490 & 400 & 893 & 3430 & 60.8 & 67300 & 737 & 720 & 19900 \\
STDEV & 112 & 7 & 12 & 95 & 1 & 1661 & 14 & 16 & 317 \\
\%RSD & 1 & 2 & 1 & 3 & 2 & 2 & 2 & 2 & 2 \\
\hline \hline
\end{tabular}

C of A - Certificate of Analysis 
WSRC-STI-2007-00438

SRNL-RPP-2007-00020

Table F - 17. IC Data for High Purity Standard E.

\begin{tabular}{ccc}
\hline \hline & $\begin{array}{c}\mathbf{C l} \\
\mathbf{m g} / \mathbf{L}\end{array}$ & $\begin{array}{c}\mathbf{S O}_{\mathbf{4}} \\
\mathbf{m g} / \mathbf{L}\end{array}$ \\
\hline \hline Standar E & 2260 & 10900 \\
Standar E & 2080 & 10900 \\
Standar E & 2110 & 10900 \\
Standar E & 2080 & 10800 \\
Standar E & 1990 & 10900 \\
\hline C of A & 2150 & 2400 \\
Average & 2100 & 10900 \\
STDEV & 98 & 45 \\
\%RSD & 95 & 100 \\
\hline \hline
\end{tabular}

C of A - Certificate of Analysis

Table F - 18. ICP Data for High Purity Standard E.

\begin{tabular}{cccccccccc}
\hline \hline & $\begin{array}{c}\mathbf{A l} \\
\mathbf{m g} / \mathbf{L}\end{array}$ & $\begin{array}{c}\mathbf{C a} \\
\mathbf{m g} / \mathbf{L}\end{array}$ & $\begin{array}{c}\mathbf{C r} \\
\mathbf{m g} / \mathbf{L}\end{array}$ & $\begin{array}{c}\mathbf{K} \\
\mathbf{m g} / \mathbf{L}\end{array}$ & $\begin{array}{c}\mathbf{M o} \\
\mathbf{m g} / \mathbf{L}\end{array}$ & $\begin{array}{c}\mathbf{N a} \\
\mathbf{m g} / \mathbf{L}\end{array}$ & $\begin{array}{c}\mathbf{N i} \\
\mathbf{m g} / \mathbf{L}\end{array}$ & $\begin{array}{c}\mathbf{P O}_{\mathbf{4}} \\
\mathbf{m g} / \mathbf{L}\end{array}$ & $\begin{array}{c}\mathbf{S O}_{\mathbf{4}} \\
\mathbf{m g} / \mathbf{L}\end{array}$ \\
\hline \hline Standard E & 9080 & 38.9 & 290 & 3280 & 29.1 & 88100 & 39.0 & 1153 \\
Standard E & 8930 & 40.1 & 294 & 3120 & 30.6 & 86100 & 38.7 & 1098 & 2481 \\
Standard E & 9040 & 37.3 & 292 & 3160 & 29.7 & 88900 & 38.7 & 1122 & 2421 \\
Standard E & 9090 & 37.6 & 287 & 3270 & 29.4 & 89000 & 38.0 & 1079 & 2424 \\
Standard E & 9120 & 39.5 & 298 & 3360 & 30.2 & 91300 & 38.6 & 1131 & 2487 \\
Standard E & 9030 & 38.9 & 290 & 3430 & 28.8 & 92300 & 38.6 & 1122 & 2421 \\
Standard E & 9000 & 39.5 & 293 & 3380 & 29.6 & 92000 & 38.5 & 1113 & 2454 \\
Standard E & 8990 & 37.8 & 285 & 3340 & 28.2 & 91400 & 36.8 & 1082 & 2367 \\
Standard E & 8790 & 37.7 & 286 & 3300 & 29.2 & 90300 & 36.7 & 1131 & 2460 \\
Standard E & 8980 & 37.9 & 288 & 3390 & 30.9 & 90700 & 37.4 & 1110 & 2514 \\
\hline C of A & 9150 & 40 & 300 & 3250 & 30 & 89000 & 40 & 1200 & 2400 \\
Average & 9000 & 38.5 & 290 & 3300 & 29.6 & 90000 & 38.1 & 1110 & 2460 \\
STDEV & 95 & 1 & 4 & 100 & 0.8 & 1959 & 0.8 & 23 & 51 \\
\%RSD & 1 & 3 & 1 & 3 & 3 & 2 & 2 & 2 \\
\hline \hline
\end{tabular}

C of A - Certificate of Analysis 
WSRC-STI-2007-00438

SRNL-RPP-2007-00020

\subsection{Appendix G: XRF Sample and Standard Counting Statistics}

Table G - 1. WD-XRF Counting Uncertainty of RPP Acidified Simulants.

Envelope A (AN-105 \& AP-101 simulant), Envelope C (AN-107 simulant), and Envelope B/D (AZ-101 simulant) Analysis

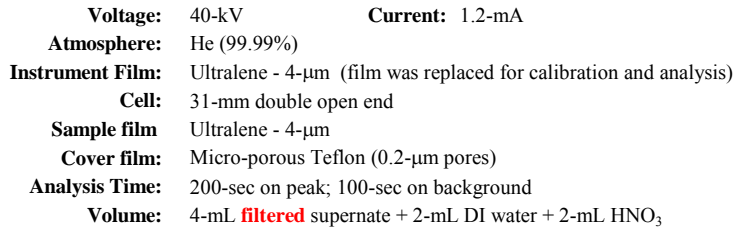

\begin{tabular}{|c|c|c|c|c|c|c|c|c|c|c|}
\hline & $\begin{array}{c}\text { Al } \\
\text { Counting } \\
\text { Uncertainty } \\
(\%) \\
\end{array}$ & $\begin{array}{c}\text { Ca } \\
\text { Counting } \\
\text { Uncertainty } \\
(\%) \\
\end{array}$ & $\begin{array}{c}\text { Cr } \\
\text { Counting } \\
\text { Uncertainty } \\
(\%) \\
\end{array}$ & $\begin{array}{c}\text { Mo } \\
\text { Counting } \\
\text { Uncertainty } \\
(\%) \\
\end{array}$ & $\begin{array}{c}\mathrm{Ni} \\
\text { Counting } \\
\text { Uncertainty } \\
(\%) \\
\end{array}$ & $\begin{array}{c}\text { K } \\
\text { Counting } \\
\text { Uncertainty } \\
(\%) \\
\end{array}$ & $\begin{array}{c}\text { Na } \\
\text { Counting } \\
\text { Uncertainty } \\
(\%) \\
\end{array}$ & $\begin{array}{c}\mathrm{SO}_{4} \\
\text { Counting } \\
\text { Uncertainty } \\
(\%) \\
\end{array}$ & $\begin{array}{c}\mathrm{PO}_{4} \\
\text { Counting } \\
\text { Uncertainty } \\
(\%) \\
\end{array}$ & $\begin{array}{c}\text { Cl } \\
\text { Counting } \\
\text { Uncertainty } \\
(\%) \\
\end{array}$ \\
\hline AN-105 & 0.58 & & 0.69 & 0.21 & & 0.37 & 0.86 & 1.83 & 3.31 & 0.31 \\
\hline AN-105 & 0.59 & & 0.70 & 0.21 & & 0.38 & 0.90 & 1.88 & 3.39 & 0.31 \\
\hline AN-105 & 0.59 & & 0.70 & 0.21 & & 0.38 & 0.89 & 1.94 & 3.35 & 0.31 \\
\hline AN-105 & 0.58 & & 0.70 & 0.21 & & 0.37 & 0.87 & 1.94 & 3.46 & 0.31 \\
\hline AN-105 & 0.59 & & 0.69 & 0.21 & & 0.37 & 0.91 & 1.83 & 3.43 & 0.31 \\
\hline AN-105 & 0.59 & & 0.69 & 0.21 & & 0.37 & 0.91 & 1.93 & 3.39 & 0.31 \\
\hline AN-105 & 0.59 & & 0.70 & 0.21 & & 0.38 & 0.90 & 1.93 & 3.41 & 0.31 \\
\hline AN-105 & 0.58 & & 0.69 & 0.21 & & 0.37 & 0.89 & 1.93 & 3.43 & 0.31 \\
\hline AN-105 & 0.58 & & 0.70 & 0.21 & & 0.38 & 0.90 & 1.88 & 3.41 & 0.31 \\
\hline AN-105 & 0.59 & & 0.70 & 0.21 & & 0.38 & 0.92 & 1.94 & 3.45 & 0.31 \\
\hline AN-105 & 0.61 & & 0.72 & 0.22 & & 0.39 & 0.95 & 1.97 & 3.48 & 0.32 \\
\hline Average & 0.59 & & 0.70 & 0.21 & & 0.38 & 0.90 & 1.91 & 3.41 & 0.31 \\
\hline AP-101 & 0.74 & & 1.27 & 0.22 & & 0.16 & 0.91 & 0.77 & 1.94 & 0.54 \\
\hline AP-101 & 0.74 & & 1.26 & 0.22 & & 0.16 & 0.92 & 0.78 & 1.97 & 0.53 \\
\hline AP-101 & 0.75 & & 1.26 & 0.22 & & 0.16 & 0.91 & 0.79 & 1.98 & 0.53 \\
\hline AP-101 & 0.75 & & 1.25 & 0.22 & & 0.16 & 0.94 & 0.77 & 1.99 & 0.53 \\
\hline AP-101 & 0.74 & & 1.24 & 0.22 & & 0.16 & 0.91 & 0.77 & 1.95 & 0.53 \\
\hline AP-101 & 0.75 & & 1.25 & 0.22 & & 0.16 & 0.92 & 0.78 & 1.97 & 0.53 \\
\hline AP-101 & 0.74 & & 1.27 & 0.22 & & 0.16 & 0.92 & 0.78 & 2.01 & 0.53 \\
\hline AP-101 & 0.73 & & 1.26 & 0.22 & & 0.16 & 0.89 & 0.77 & 1.95 & 0.53 \\
\hline AP-101 & 0.75 & & 1.25 & 0.22 & & 0.16 & 0.93 & 0.77 & 1.97 & 0.53 \\
\hline AP-101 & 0.74 & & 1.26 & 0.22 & & 0.16 & 0.91 & 0.77 & 1.95 & 0.53 \\
\hline AP-101 & 0.76 & & 1.32 & 0.23 & & 0.16 & 0.97 & 0.80 & 1.99 & 0.54 \\
\hline Average & 0.74 & & 1.26 & 0.22 & & 0.16 & 0.92 & 0.78 & 1.97 & 0.53 \\
\hline AN-107 & 3.03 & 2.40 & & 0.21 & 0.45 & 0.54 & 0.85 & 0.68 & 2.33 & 0.58 \\
\hline AN-107 & 3.02 & 2.38 & & 0.21 & 0.45 & 0.55 & 0.83 & 0.68 & 2.31 & 0.58 \\
\hline AN-107 & 3.02 & 2.36 & & 0.21 & 0.45 & 0.54 & 0.85 & 0.68 & 2.28 & 0.57 \\
\hline AN-107 & 2.88 & 2.42 & & 0.21 & 0.45 & 0.54 & 0.85 & 0.68 & 2.26 & 0.56 \\
\hline AN-107 & 3.02 & 2.38 & & 0.21 & 0.45 & 0.54 & 0.85 & 0.67 & 2.27 & 0.57 \\
\hline AN-107 & 3.16 & 2.36 & & 0.21 & 0.45 & 0.54 & 0.85 & 0.67 & 2.27 & 0.57 \\
\hline AN-107 & 2.96 & 2.39 & & 0.21 & 0.45 & 0.54 & 0.85 & 0.67 & 2.29 & 0.57 \\
\hline AN-107 & 3.07 & 2.36 & & 0.21 & 0.45 & 0.54 & 0.85 & 0.67 & 2.27 & 0.57 \\
\hline AN-107 & 2.90 & 2.39 & & 0.21 & 0.45 & 0.54 & 0.84 & 0.67 & 2.27 & 0.57 \\
\hline AN-107 & 2.98 & 2.45 & & 0.21 & 0.45 & 0.54 & 0.85 & 0.67 & 2.31 & 0.57 \\
\hline AN- 107 & 2.87 & 2.39 & & 0.22 & 0.47 & 0.56 & 0.89 & 0.69 & 2.36 & 0.58 \\
\hline Average & 2.99 & 2.39 & & 0.21 & 0.45 & 0.54 & 0.85 & 0.68 & 2.29 & 0.57 \\
\hline AZ-101 & & & 1.17 & 0.20 & & 0.56 & 2.29 & 1.40 & & 1.01 \\
\hline AZ-101 & & & 1.16 & 0.20 & & 0.55 & 2.15 & 1.41 & & 0.98 \\
\hline AZ-101 & & & 1.15 & 0.20 & & 0.56 & 2.21 & 1.41 & & 0.99 \\
\hline AZ-101 & & & 1.11 & 0.21 & & 0.54 & 2.07 & 1.34 & & 0.96 \\
\hline AZ-101 & & & 1.17 & 0.20 & & 0.56 & 2.24 & 1.44 & & 1.00 \\
\hline AZ-101 & & & 1.15 & 0.20 & & 0.55 & 2.17 & 1.41 & & 0.96 \\
\hline AZ-101 & & & 1.15 & 0.20 & & 0.55 & 2.23 & 1.42 & & 0.98 \\
\hline AZ-101 & & & 1.16 & 0.20 & & 0.56 & 2.19 & 1.41 & & 0.99 \\
\hline AZ-101 & & & 1.15 & 0.20 & & 0.56 & 2.19 & 1.42 & & 1.00 \\
\hline AZ-101 & & & 1.16 & 0.20 & & 0.56 & 2.24 & 1.43 & & 1.01 \\
\hline AZ-101 & & & 1.21 & 0.21 & & 0.57 & 2.38 & 1.50 & & 0.99 \\
\hline Average & & & 1.16 & 0.20 & & 0.56 & 2.21 & 1.42 & & 0.99 \\
\hline
\end{tabular}


Table G - 2. WD-XRF Counting Uncertainty of RPP Basic Simulants.

Envelope A (AN-105 \& AP-101 simulant), Envelope C (AN-107 simulant), and Envelope B/D (AZ-101 simulant) Analysis

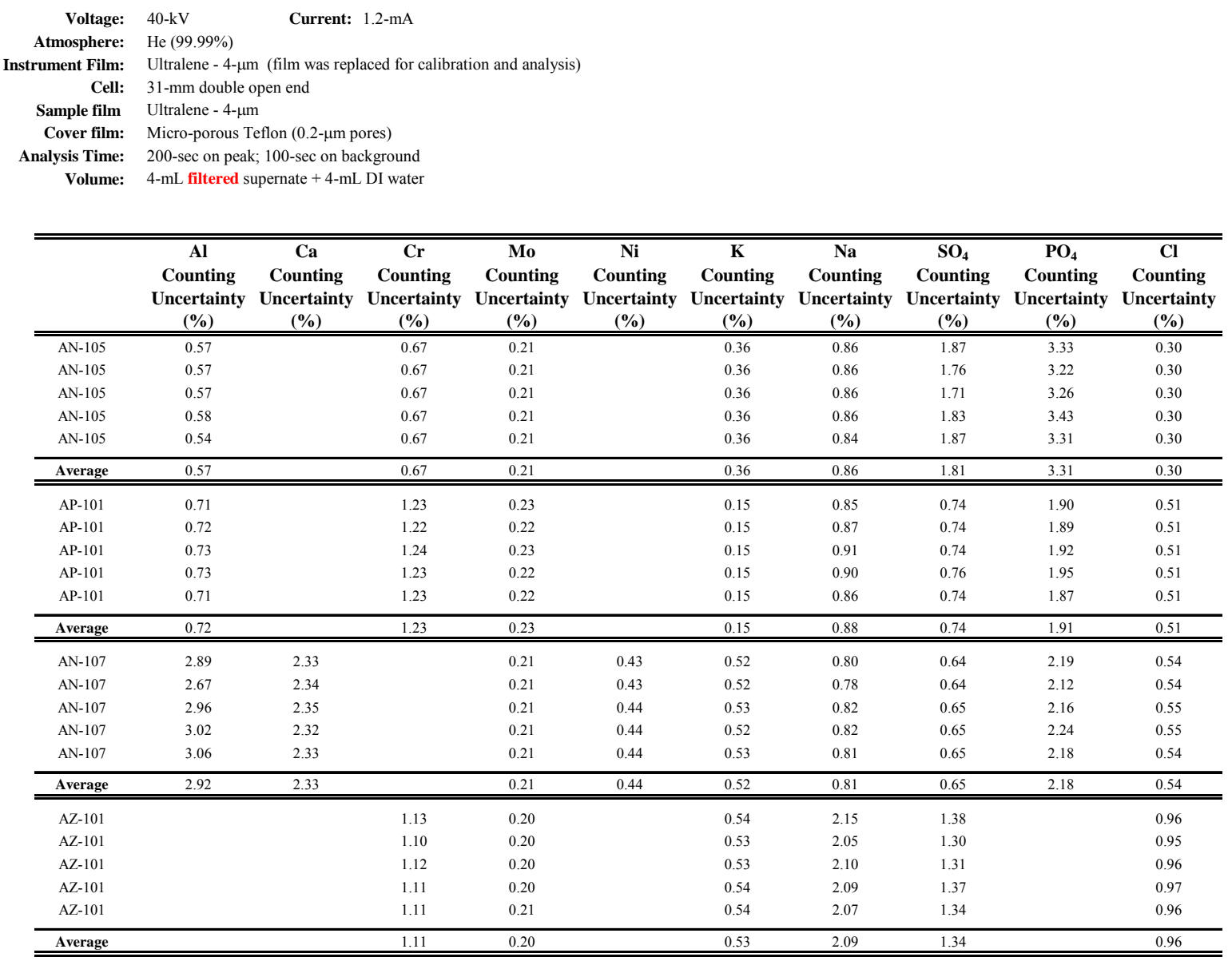


WSRC-STI-2007-00438

SRNL-RPP-2007-00020

\section{DISTRIBUTION:}

L. M. Chandler, 773-A

R. E. Edwards, 773-A

F. M. Pennebaker, 773-A

C. C. Herman, $773-42$ A

T. B. Edwards, 773-42A

J. P. Vaughan, 773-41A

RPP Files, c/o S. J. Boggs, 773-A 